\title{
ZOOTAXA
}

3903

\section{Review of the Neotropical scale insects formerly assigned to Coelostomidiidae and here transferred to a new tribe within the Monophlebidae (Hemiptera: Sternorrhyncha: Coccoidea)}

I. FOLDI ${ }^{1} \&$ P. J. GULLAN ${ }^{2}$

${ }^{1}$ Muséum national d'Histoire naturelle, Departement Systématique \& Evolution, UMR 7205 (OSEB), CP 50 Entomologie, 45 rue Buffon, 75005 Paris, France. E-mail: foldi@mnhn.fr

${ }^{2}$ Division of Evolution, Ecology \& Genetics, Research School of Biology, The Australian National University, Canberra, A.C.T. 2601, Australia.E-mail: penelope.gullan@anu.edu.au

\section{6}

Magnolia Press

Auckland, New Zealand 
I. FOLDI \& P. J. GULLAN

Review of the Neotropical scale insects formerly assigned to Coelostomidiidae and here transferred to a new tribe within the Monophlebidae (Hemiptera: Sternorrhyncha: Coccoidea)

(Zootaxa 3903)

62 pp.; $30 \mathrm{~cm}$.

24 Dec. 2014

ISBN 978-1-77557-611-2 (paperback)

ISBN 978-1-77557-612-9 (Online edition)

FIRST PUBLISHED IN 2014 BY

Magnolia Press

P.O. Box 41-383

Auckland 1346

New Zealand

e-mail: zootaxa@mapress.com

http://www.mapress.com/zootaxa/

(C) 2014 Magnolia Press

ISSN 1175-5326 (Print edition)

ISSN 1175-5334 (Online edition) 


\section{Table of contents}

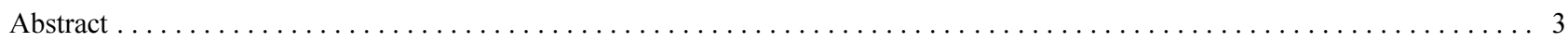

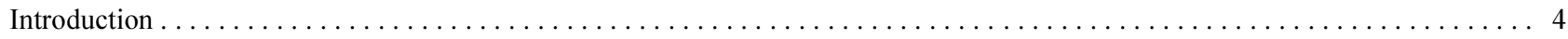

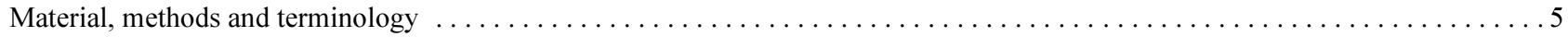

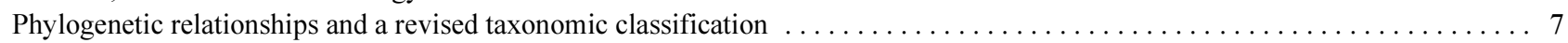

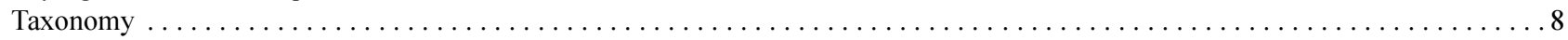

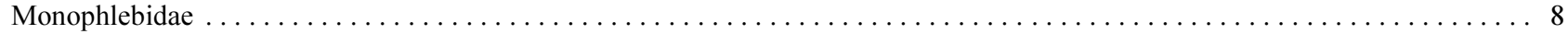

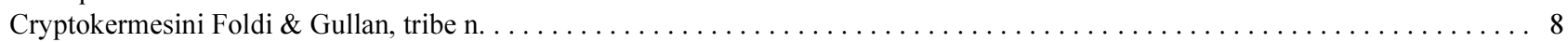

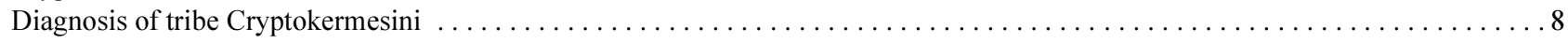

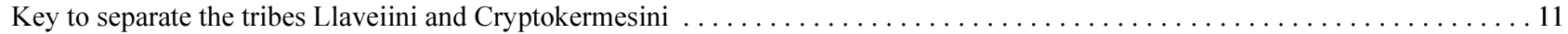

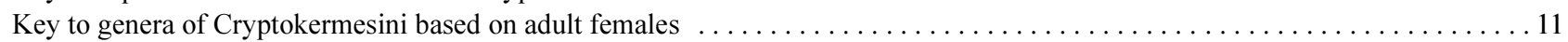

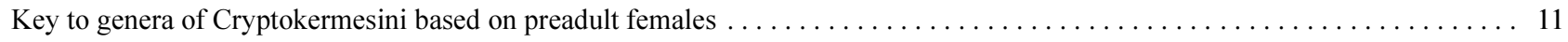

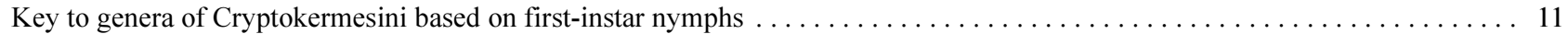

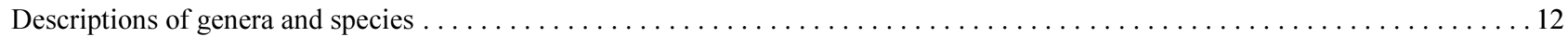

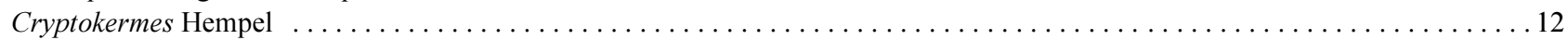

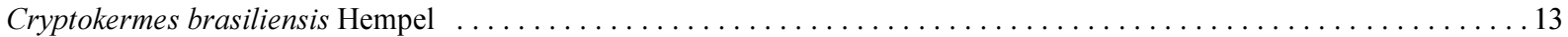

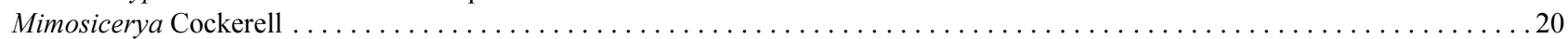

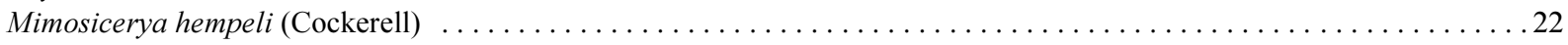

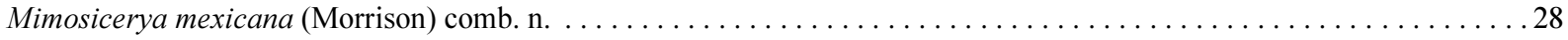

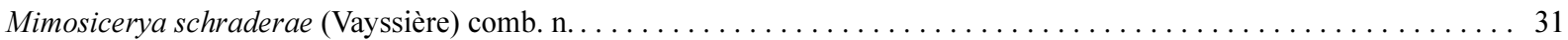

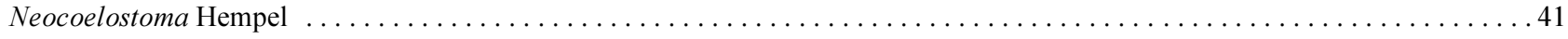

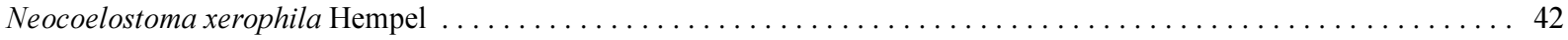

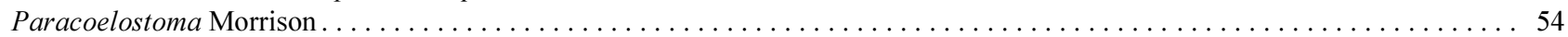

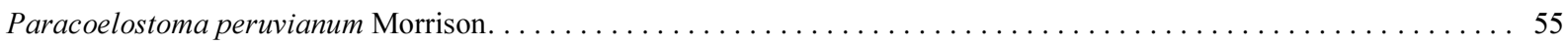

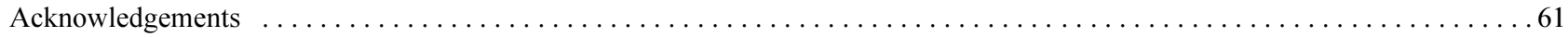

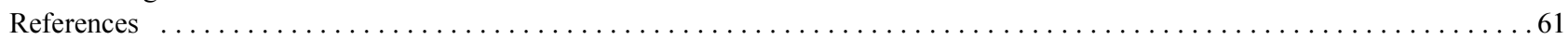

\section{Abstract}

This study reviews the status of all Neotropical genera and species of Coelostomidiidae (Hemiptera: Coccoidea) and transfers them to the family Monophlebidae in the Cryptokermesini Foldi \& Gullan tribe n. (the tribe Cryptokermini Tao \& Hao is recognised here as a nomen nudum). This change of family placement for Neotropical taxa is based on the morphology of adult males, as supported by the phylogenetic study of Hodgson \& Hardy (2013), and by unpublished DNA data. New diagnoses are provided for each of the four recognised genera of Cryptokermesini: Cryptokermes Hempel, Mimosicerya Cockerell, Neocoelostoma Hempel and Paracoelostoma Morrison. The genus Nautococcus Vayssière is considered here to be a junior synonym (syn. n.) of Mimosicerya and the type species of Nautococcus, N. schraderae Vayssière, thus becomes M. schraderae (Vayssière) comb. n. Cryptokermes mexicanus Morrison is transferred to Mimosicerya as M. mexicana (Morrison) comb. n. Also Cryptokermes mimosae Foldi does not fit the morphological concept of Cryptokermes and is excluded from this genus and revision, and from the new tribe; its taxonomic position is uncertain and requires further study. All type species of the Cryptokermesini, including N. schraderae (as M. schraderae), are redescribed and illustrated based on most female instars and available adult males, examined using optical and scanning electron microscopes. Adult males are described and illustrated only for M. schraderae and N. xerophila. Keys are provided to distinguish the Neotropical monophlebid tribes Cryptokermesini and Llaveiini and to recognise each cryptokermesine genus based on female instars and first-instar nymphs. The included species of Cryptokermesini and their known distributions are: Cryptokermes brasiliensis Hempel from Brazil and C. oaxaensis Foldi from Mexico; Mimosicerya hempeli (Cockerell) from Brazil, M. mexicana from Mexico, M. schraderae from Panama and M. williamsi Foldi from Venezuela; Neocoelostoma xerophila Hempel from Argentina, Bolivia, Brazil, Paraguay and Uruguay; and Paracoelostoma peruvianum Morrison from Peru. All these insects live exposed on their host plant, either inside a secreted test (as for female and immature male instars of Cryptokermes, Neocoelostoma and Paracoelostoma) or the strongly sclerotised derm of the preadult female protects the adult (as for all species of Mimosicerya). Adult females of Mimosicerya are pupillarial, remaining within the exuviae of the previous instar, whereas adult females of the other three genera either remain within their test (and some species may be pupillarial) or escape the test to oviposit. The morphology of the adult female and often the preadult female is strongly modified, with reduction of antennae and legs, and with legs lacking in some species.

Key words: Cryptokermesini, Cryptokermes, Mimosicerya, Nautococcus, Neocoelostoma, Paracoelostoma 


\section{Résumé}

Revue des Cochenilles néotropicales anciennement assignées à la famille des Coelostomidiidae et ici transférées à une nouvelle tribu dans la famille des Monophlebidae (Hemiptera: Sternorrhyncha: Coccoidea).

Cette étude révise le statut de tous les genres et espèces Néotropicaux des Coelostomidiidae (Hemiptera, Coccoidea) et propose leur transfert dans la famille des Monophlebidae dans la tribu de Cryptokermesini Foldi \& Gullan tribe n. (la tribu Cryptokermini Tao \& Hao ici reconnu comme nomen nudum). Ce changement de statut des Coelostomidiidae Néotropicaux est basé sur une étude phylogénétique des adultes mâles (Hodgson \& Hardy, 2013) et sur des données moléculaires non publiées. A la suite de notre étude, nous confirmons que les Coelostomidiidae sont présents seulement en Nouvelle-Zélande. Une nouvelle diagnose est fournie pour les quatre genres reconnus des Cryptokermesini: Cryptokermes Hempel, Mimosicerya Cockerell, Neocoelostoma Hempel et Paracoelostoma Morrison. Le genre Nautococcus Vayssière est consideré comme synonyme junior (syn. n.) de Mimosicerya et l'espèce type de Nautococcus, $N$. schraderae devient M. schraderae (Vayssière) comb. n. Cryptokermes mexicanus Morrison est transferé dans le genre de Mimosicerya comme M. mexicana (Morrison) comb. n.). Chacune des espèces types des Cryptokermesini est redécrite et illustrée à partir des premières stades larvaires, des préadultes et des femelles adultes; les adultes mâles sont décrits et illustrés seulement pour $M$. schraderae et $N$. xerophila. Une clef est proposée pour reconnaître chaque cryptokermesine genus basé sur les adultes, préadultes femelles et les premières stades larvaires et aussi séparer les Neotropicale tribus monophlebines le Cryptokermesini et le Llaveiini. Les espèces incluses de Cryptokermesini et leur distribution connus sont: Cryptokermes brasiliensis Hempel, Brésil; C. oaxaensis Foldi, Mexique; Mimosicerya hempeli (Cockerell), Brésil; M. mexicana (Morrison), Mexique; M. schraderae (Vayssière), Panama; M. williamsi Foldi, Venezuela; Neocoelostoma xerophila Hempel, Argentine, Bolivie, Brésil, Paraguay et Uruguay; Paracoelostoma peruvianum Morrison, Pérou. Ces insects vivent sur les parties aériennes de leur plantes-hôtes, soit à l'intérieur d'un test sécrété (par la femelle et le male des stades immatures de Cryptokermes, Neocoelostoma et Paracoelostoma) soit dans l'exuvie du préadulte fortement sclérifiée (toutes les espèces de Mimosicerya). Les adultes femelles de Mimosicerya sont dites pupillariales restant à l'intérieur de l'exuvie du stade précédent, tandis que des femelles des autres trois genres, soit restent à l'intérieur du test (quelques espèces peuvent être pupillariales) ou s'en échappent pour pondre. La morphologie des femelles adultes et souvent des femelles préadultes est considérablement modifiée avec la réduction des antennes et des pattes, voir la perte total des pattes.

\section{Introduction}

The Coccoidea, or scale insects, are small sap-sucking insects with about 8000 species known worldwide and including many of economic importance (Ben-Dov et al. 2014). Extreme sexual dimorphism exists between the paedomorphic females and dipteriform males. These small insects are divided into two informal groups, the archaeococcoids and the neococcoids, based on the presence or absence of features interpreted as ancestral or derived (Foldi, 2005; Gullan \& Cook, 2007). The archaeococcoids are characterised by the presence of abdominal spiracles in all instars, compound eyes in adult males and an XX-XO sex determination system (features found in most other Hemiptera), whereas the neococcoids lack abdominal spiracles in all instars, lack compound eyes in adult males and have the synapomorphic paternal genome elimination (PGE) system (Cook et al., 2002; Normark, 2003; Ross et al., 2010) and share derived DNA sequences (Cook et al., 2002; Gullan \& Cook, 2007; Yokogawa \& Yahara, 2009). The archaeococcoids comprise up to 15 extant families and the neococcoids up to 18 extant families (Foldi, 2005; Gullan \& Cook, 2007; Ben-Dov et al., 2014). Although neococcoids have been shown to form a monophyletic group, the relationships of most archaeococcoid higher taxa are not resolved at present (Foldi, 1997; Cook et al., 2002; Gullan \& Cook, 2007; Hodgson \& Foldi, 2005; Hodgson \& Hardy, 2013). Furthermore, the affiliations of some archaeococcoid genera and even their family-level status are uncertain. However, the continuing acquisition and analysis of DNA sequence data, and phylogenetic analyses based on adult female and male morphology are helping to reconstruct scale insect family relationships.

There are 135 named species of archaeococcoids from the Neotropics (Ben-Dov et al., 2014), including a newly described species of Laurencella (Foldi \& Williams, 2013). These species belong to eight families: Callipappidae (one species), Carayonemidae (four species), Coelostomidiidae (six species), Margarodidae sensu stricto (12 species), Matsucoccidae (3 species), Monophlebidae (40 species), Ortheziidae (66 species) and Stigmacoccidae (three species). There has been recent taxonomic work on the Neotropical Callipappidae (Foldi, 2009), Carayonemidae (Kozár \& Konczné Benedicty, 2000; Kozár \& Foldi, 2002), Monophlebidae (Unruh \& Gullan, 2008; Williams \& Gullan, 2008; Foldi, 2009; Foldi \& Williams, 2013), Ortheziidae (Kozár, 2004), 
Stigmacoccidae (Foldi, 2006; Hodgson et al., 2007), and one species of Coelostomidiidae (Foldi, 2009), but not on species of Margarodidae s.s. or Matsucoccidae.

Originally, Morrison (1927) erected the subfamily Coelostomidiinae with three tribes: Coelostomidiini, Marchalini and Platycoelostomini, with the New Zealand Coelostomidia Cockerell as the type genus of Coelostomidiini. Koteja (1974) elevated the subfamily to family rank as Coelostomidiidae, but later Koteja (1996) narrowed the family to include just members of Morrison's Coelostomidiini, and this classification is accepted widely now (Foldi, 2005; Hodgson \& Foldi, 2006; Gullan \& Cook, 2007). Currently the Coelostomidiidae includes Coelostomidia (six species) and Ultracoelostoma Cockerell (three species) from New Zealand (Morales, 1991), and Cryptokermes Hempel (four species), Nautococcus Vayssière (one species), Neocoelostoma Hempel (one species), Mimosicerya Cockerell (two species), and Paracoelostoma Morrison (one species) from the Neotropical area (Mexico, Central and South America) (Morrison, 1928; Williams \& Gullan, 2008; Foldi, 2009). The validity of the genus Nautococcus (Vayssière, 1939) from Panama was questioned by Williams \& Gullan (2008), who suggested that Mimosicerya and Nautococcus are identical, although the described species are not the same. They excluded Nautococcus from the tribe Llaveiini of the Monophlebidae. It was placed in Monophlebidae by Ben-Dov (2005, 2011, 2014). Vayssière and Hughes-Schrader (1948) commented that Nautococcus undoubtedly belonged with the coelostomidiids based on morphology but that it had cytology ( $2 n=6$ in females; $2 n=5$ in males) similar to Llaveiini. However, there is no information on karyotypes in coelostomidiids.

Most Neotropical coelostomidiids are test forming (Figs 1A, D, E \& F), with the immature insects secreting a thick-walled protective test that enlarges during their development. At maturity, the adult female either stays and oviposits within the test or exits and oviposits elsewhere. In contrast, species of Mimosicerya do not secrete a test but the preadult cuticle becomes heavily sclerotised and forms a protective cover for the adult female (Fig. 1B, C), which can, therefore, be considered as "pupillarial" because it remains and oviposits within the exuviae of the previous instar. Morrison (1928) noted that the anal tube of the preadult females of Cryptokermes and Paracoleostoma is often retained within that of the adult, which may suggest that they are pupillarial too. In Neocoelostoma, the adult female escapes from the test to seek a sheltered position on the bark, and exudes a mass of cottony white filaments prior to ovipositing within (from notes of H.L. Parker associated with specimens in USNM). Related to this behaviour, the adult female of Neocoelostoma has well-developed legs, as typical in monophlebids, whereas the adult females of Cryptokermes, Mimosicerya and Paracoelostoma have highly reduced legs and those of Nautococcus are completely absent.

This paper revises the classification of the Neotropical archaeococcoid genera that currently are placed in the family Coelostomidiidae. Nautococcus schraderi Vayssière, the only species in Nautococcus, shares a number of morphological features with the other genera, as outlined by Williams \& Gullan (2008) and documented in this paper. We formally recognise Nautococcus as a junior synonym of Mimosicerya and thus N. schraderae is transferred to Mimosicerya. We also formally transfer Cryptokermes, Mimosicerya, Neocoelostoma and Paracoelostoma to the Monophlebidae in their own tribe, and provide keys to the genera based on the morphology of adult and preadult females and first-instar nymphs. These genera are close to the Neotropical tribe Llaveiini (as defined by Williams \& Gullan (2008)), but in the Llaveiini, no genus forms a test and nor do adult females have such reduced appendages.

\section{Material, methods and terminology}

Materials. Most specimens used in this study were borrowed from museums. Extensive use was made of the dry collections in the USNM, especially those made in the early 1940s by H.L. Parker, who also made notes on the insects in life. Some specimens also were collected in South America by P.J. Gullan and I. Foldi.

The following abbreviations are used for museum collections: BME: Bohart Museum of Entomology, University of California, Davis, California, U.S.A.; BMNH: The Natural History Museum, London, U.K.; IBSP: Instituto Biologico de São Paulo, Brazil; IMLA: Fundación e Instituto Miguel Lillo, Universidad Nacional de Tucumán, Tucumán, Argentina; MNHN: Muséum national d'Histoire naturelle, Paris, France; and USNM: the United States National Collection of Coccoidea of the National Museum of Natural History, Smithsonian Institution, housed at the United States Department of Agriculture (USDA), Beltsville, Maryland, U.S.A.

The International Code of Zoological Nomenclature (ICZN, 1999) requires the designation of lectotypes after 1999 to "contain an express statement of deliberate designation" (amended Article 74.7.3). We use the statement 
"here designated" to fulfill this requirement. A lectotype has been designated for Nautococcus schraderae Vayssiere because this name lacks a holotype or lectotype and unambiguous syntypes have been identified. The purpose is to provide stability of nomenclature, and designation is done in a revisionary context in agreement with the amended Recommendation $74 \mathrm{G}$ of Article 74.7.3. We have not designated a lectotype for either Cryptokermes brasiliensis Hempel or Icerya (Crypticerya) hempeli Cockerell, as we explain in the type notes for those two names.

Methods. Some dry museum material and the freshly collected specimens were slide-mounted in Canada balsam using the method described in Williams \& Granara de Willink (1992) except that xylene was used instead of clove oil. Scanning electron microscopy (SEM) was used to interpret dermal microstructures. For SEM study, the whole insects were treated in $\mathrm{KOH}$ ( $10 \%$ in water), washed in water and dehydrated in a series of alcohols -50 $\%, 70 \%$ to absolute alcohol, cleaned in an ultrasonic cleaner, critical point-dried and finally the specimens were coated in gold. Slide-mounted specimens were measured under a compound microscope; body length and width were recorded in $\mathrm{mm}$, whereas other measurements of various useful features were made in microns. Length is measured from the apex of the head to the posterior end of the body, whereas width is measured as the greatest width. Each figure shows an entire insect with the venter depicted on the right side of the illustration and the dorsum shown on the left. Special features of the specimen are enlarged around the main illustration, although enlargements are not in direct proportion to each other.

For second-instar nymphs, we were unable to determine whether the specimens examined were male or female, nor whether there is any sexual dimorphism in the second instar. Larger collections of this instar are required.

Terminology. The terms used to describe the adult female and immature insects follow those of Morrison (1928) and Foldi (2001, 2009), and for the adult male those of Hodgson \& Foldi (2006). The term cicatrix refers to an approximately circular structure with a membranous surface surrounded by a sclerotised rim; the number, size and distribution of cicatrices are useful taxonomic characters. In the genera dealt with here, there are large variations in cicatrix size and mostly the surface appears smooth. Disc-like tubercles are small circular structures that in side view have a slight to pronounced dome. Morrison (1928) described disc-like and spine-like tubercles on the derm of first-instar nymphs and preadult females of Cryptokermes species, and on the first-instar nymph of Mimosicerya hempeli. In the preadult female of $M$. hempeli, there are two kinds of disc-like tubercles: one smaller type, more densely distributed and with no central opening (Fig. 7G), and another of larger size, less common but with a visible central opening (Fig. 7J). Derm pores are named according to the presence or absence of loculi: simple pores have no loculi, whereas loculate pores can be uni-, bi-, tri-, quadri- or quinquelocular (i.e., from one to five loculi), or multilocular if there are six or more outer loculi. Raised pores are each located on a raised, circular sclerotised area of derm that has a sunken centre in which is located the multilocular pore (see Figs $3 \mathrm{M}, 22 \mathrm{H}$ ).

The following setal types are recognised on scale insects of Cryptokermesini: hairs, hair-like setae, flagellate setae, spiniform setae and spines, plus collared setae only on the adult males (Fig. 13). Hairs have a cone-like base fused to the seta, and thus lack a basal socket and setal membrane (e.g. Figs 2J, 7N). Hair-like setae have a shallow basal socket around the setal membrane (e.g. Fig. 10O). Collared setae are not present on females but occur on adult males; each seta is on a rounded mound and has a shallow collar around the basal socket, as on the adult male of M. schraderae (Fig. 13E). Flagellate setae have a rounded socket but a more or less indistinct basal collar, and the apex of the seta is flagellate (e.g. Fig. 4J). Spiniform setae have a spine-like appearance and they may be large, robust, sometimes heavily sclerotised, but have a basal socket and mostly a pointed apex (e.g. Fig. 2G). Spines lack a basal socket and are robust and sclerotised, appearing as an extension directly from the derm (e.g. Figs $2 \mathrm{~B}, 3 \mathrm{H}$ ). Abbreviations on the drawings and in descriptions of adult males of M. schraderae (Fig. 13) and N. xerophila (Fig. 19) are as follows: $a b=$ antennal bristle, or short blunt-ended seta; ads = abdominal dorsal setae; aed = aedeagus; al $=$ alar lobe; an = anus; as = abdominal sternites; at = abdominal tergites; $b$ s = bifurcated setae; bce = bulbous caudal extension; $\mathrm{c}=$ claw; camp $=$ campaniform sensillum; $\mathrm{cd}=$ claw digitule; $\mathrm{cde}=$ compound eye; $\mathrm{ce}=$ caudal extension of abdomen; $\mathrm{cp}=$ convex pore; $\mathrm{cs}=$ collared setae; $c \mathrm{co}=\mathrm{coxa}$; das = dorsal abdominal (mostly hair-like) setae; dat $=$ dorsal abdominal tergites; eph $=$ endophallus; eps $^{1,2,3}=$ pro-, meso- and metepisternum; $\mathrm{f}=$ furca; $\mathrm{fm}=$ femur; fs = fleshy seta; $\mathrm{h}=$ hamulohaltere; ha = hamuli; $\mathrm{hrs}=$ hairs; $\mathrm{hs}=$ hair-like seta; $1 \mathrm{p}=$ loculate pore; $1 \mathrm{pl}=$ lateropleurite; lpns = lateral pronotal setae; $\mathrm{med}=$ media $($ wing vein); $\mathrm{mcr}=$ midcranial ridge; $\mathrm{mdr}=$ median ridge; $\mathrm{mo}=$ mouth $; \mathrm{mp}=$ barely sclerotised pore; $\mathrm{mpns}=$ median pronotal setae; $\mathrm{mr}=$ marginal ridges; $\mathrm{msp}=$ small heavily sclerotised pores; $\mathrm{mts}=$ metatergal setae; $\mathrm{o}=$ ocellus; $\mathrm{ocs}=$ ocular sclerite; $\mathrm{pa}=$ postalare; $\mathrm{pcr}=$ precoxal 
ridges; $p d c=$ pedicel; $p^{1,2}=$ mesoprephragma and mesopostphragma; plr $^{1,2,3}=$ pro-, meso- and metathoracic pleural ridges; $\mathrm{pn}^{2}=$ mesopostnotum; $\mathrm{pn}^{3}=$ metapostnotum; $\mathrm{poc}=$ postocular ridge; pos = postoccipital suture; pra $=$ prealare; procr $=$ preocular ridge; pror $=$ preoral ridge; prsc $=$ prescutum; prscs $=$ prescutal setae; $p s=$ penial sheath; $p s c r=$ prescutal ridges; $p s p=$ penial sheath pores $($ sensilla); $p s s=$ penial sheath setae; $p t=$ postergite; $\operatorname{rad}=$ radius (wing vein); $r d=$ ridge along posterior margin of scutellum; sats = satellite seta; $s c l=$ scutellum; sclt $=$ subcostal thickening; $\mathrm{scp}=$ scape; $\mathrm{sct}=$ scutum; $\mathrm{scts}=$ scutal setae; scuts = scutocutellar sutures; $\mathrm{sp}^{1}$ and $\mathrm{sp}^{2}=$ meso- and metathoracic spiracles; $\operatorname{stn}^{1,2,3}=$ pro-, meso- and metasternum; $\operatorname{stn}^{1} \mathrm{a}=$ sternal lateral apophysis; $\operatorname{ta}=$ tarsus, 2 segmented $\left(\mathrm{ta}^{1}\right.$ and $\left.\mathrm{ta}^{2}\right)$; tcs = tarsal campaniform sensillum; $\mathrm{td}=$ tarsal digitule; teg = tegula; tegs = tegular setae; $\mathrm{ti}=$ tibia; $\mathrm{tr}=$ trochanter; $\mathrm{tspu}=$ tibial spurs; vas = ventral abdominal setae (hair-like and hairs) in broader bands than on dorsum; vmcr $=$ ventral midcranial ridge.

\section{Phylogenetic relationships and a revised taxonomic classification}

The adult females and immature instars of the South American and New Zealand Coelostomidiidae share a number of morphological features as described by Morrison (1928). The adult females exhibit much variation among the genera especially in antennal and leg development and degree of sclerotisation, but the two New Zealand genera differ from the South American species in having a well-developed anal tube bearing hairs, pores and sometimes lobes, and always have a sclerotised inner ring lacking polygonal pores (Morales, 1991), whereas the anal tube in the Neotropical genera is probably always membranous but often retains the tube of the previous instar, which has a band of polygonal pores at the inner end. The second- and third-instar females of the New Zealand and South American coelostomidiid genera share the following morphological features: posterior end of the abdomen surrounding anal opening with derm sclerotised to varying degrees; antennae and legs reduced in size but segments usually distinct; anal tube long with a ring or band of polygonal wax pores at inner end; cicatrices present and usually present on both dorsum and venter; however, disc-like tubercles are absent in the New Zealand species. The first-instar nymphs of New Zealand coelostomidiids have simple pores (Morales, 1991) but lack the distinctive disc-like tubercles present in some of the South American genera, and there is only one pair of caudal setae in New Zealand species whereas the South American species have two to many pairs, as in the first-instar nymphs of most Monophlebidae.

A relationship between the Coelostomidiidae (sensu Koteja, 1996; Hodgson \& Hardy, 2013) and the Monophlebidae was suggested by Gullan \& Sjaarda (2001), based on a cladistic analysis of morphological data from 27 archaeococcoid genera. A recent work (Hodgson \& Hardy, 2013) on the phylogeny of Coccoidea, based on the morphology of macropterous males, found the Coelostomidiidae to be paraphyletic with respect to Monophlebidae. The included South American coelostomidiid representatives, Nautococcus (synonymised with Mimosicerya later in this paper) and Neocoelostoma, formed a clade sister to Monophlebidae rather than being grouped with the New Zealand members of Coelostomidiidae; the authors suggested that these South American taxa could be treated either as a separate family-level group or transferred to the Monophlebidae. The available adult males of the Neotropical coelostomidiids show a combination of features found in the Monophlebidae and the New Zealand coelostomidiids, with the adult male of Neocoelostoma resembling those of monophlebids such as Laurencella colombiana Foldi \& Watson and Drosicha dalbergiae (Stebbing) more than does the adult male of Nautococcus. Neocoelostoma and Nautococcus share the following adult male apomorphies with the Monophlebidae but not with the New Zealand Coelostomidiidae (character states typical of NZ taxa in parentheses): ocelli located dorsal to compound eyes (ocelli posterior to compound eyes); claws with one pair of non-capitate, usually setose, digitules (claws with capitate digitules and often more than one pair); paired caudal extensions on at least one posterior abdominal segment (lacking caudal extensions); anus at apex of a sclerotised tube (anal tube apparently membranous) (Hodgson \& Foldi, 2006: Hodgson \& Hardy, 2013).

Preliminary analysis of nucleotide sequence data (L.G. Cook, T. Kondo and P.J. Gullan, unpublished) from the small subunit ribosomal RNA gene (SSU rRNA or 18S) and including taxa of New Zealand and Neotropical Coelostomidiidae, Australian and Neotropical Monophlebidae and representatives from other archaeococcoid families, show the Neotropical coelostomidiids (Nautococcus, Neocoelostoma and Cryptokermes) to be related to the monophlebid tribes Llaveiini (Laurencella and Protortonia) and Monophlebulini (Monophlebulus and Melaleucoccus) and to be unrelated to the New Zealand coelostomidiids. 
Although the insects of most genera of coelostomidiids (both New Zealand and South American) develop within a test on their host plant, the nature of the test appears to differ between the New Zealand and Neotropical genera, with those of the latter typically being composed of a yellow to orange, brown or reddish-brown resin and fully exposed on the plant, whereas the New Zealand species have tests that are more waxy and often are at least partially hidden in the bark. Similarities in female morphology between New Zealand and South American taxa presumably result from convergent adaptation to living confined within a test. Examples of such adaptations are (i) the reduction of appendages in instars with limited or no mobility, and (ii) the apical anal opening and its associated pores and well-developed anal tube to allow efficient elimination of honeydew from the test.

Here we formally transfer the genera Cryptokermes, Mimosicerya (including Nautococcus), Neocoelostoma and Paracoelostoma to the Monophlebidae and place these four genera into their own tribe, which is named and described below.

\section{Taxonomy}

\section{Monophlebidae}

\section{Cryptokermesini Foldi \& Gullan, tribe n.}

Type genus: Cryptokermes Hempel

Cryptokermini Tang \& Hao, 1995: 121. Nomen nudum (here recognised)

Cryptokermesini; Williams, 2013: 330. Emendation of spelling

Tang \& Hao (1995) used the name Cryptokermini to include four genera and five species in the subfamily Coelostomidiinae (which they included in Monophlebidae), but they did not specify which genera and species were included nor did they provide a description or definition of their new tribe. Their name is thus unavailable (see Article 13 of the International Code of Zoological Nomenclature (ICZN 1999)). Williams (2013) emended the name Cryptokermini to Cryptokermesini but did not realise that the earlier name was invalid. Here we validate the name Cryptokermesini by providing a description of the tribe and a key to the included genera of the tribe.

The tribe Cryptokermesini includes four genera, Cryptokermes, Mimosicerya, Neocoelostoma and Paracoelostoma, which contain the following species after our revision:

(i) Cryptokermes Hempel, 1900, with two species: C. brasiliensis Hempel, 1900, from Brazil, and C. oaxaensis Foldi, 2011, from Mexico.

(ii) Mimosicerya Cockerell, with four species: M. hempeli (Cockerell, 1899) from Brazil, M. mexicana (Morrison, 1927) from Mexico, M. schraderae (Vayssière, 1939) from Panama, and M. williamsi Foldi, 2009, from Venezuela. We have compared type material of Mimosicerya and Nautococcus and believe the genera to be the same, but we recognise the species $N$. schraderae Vayssière as distinct from the described species of Mimosicerya and thus N. schraderae is transferred to Mimosicerya; we also transfer Cryptokermes mexicanus Morrison to Mimosicerya as M. mexicana (refer to the taxonomic treatment of Mimoiscerya below).

(iii) Neocoelostoma Hempel, 1932, a monotypic genus with species N. xerophila Hempel, 1932, described from Brazil, but subsequently collected in Argentina, Bolivia, Brazil, Paraguay and Uruguay.

(iv) Paracoelostoma Morrison, 1927, a monotypic genus with species P. peruvianum Morrison, 1927, from Peru.

\section{Diagnosis of tribe Cryptokermesini}

Species of Cryptokermes, Neocoelostoma and Paracoelostoma are test forming (Fig. 1A, D, E \& F), whereas in Mimosicerya, the immature insects develop exposed on the host plant and the preadult cuticle becomes heavily sclerotised as a protective cover for the pharate adult female (Fig. 1B, C). 

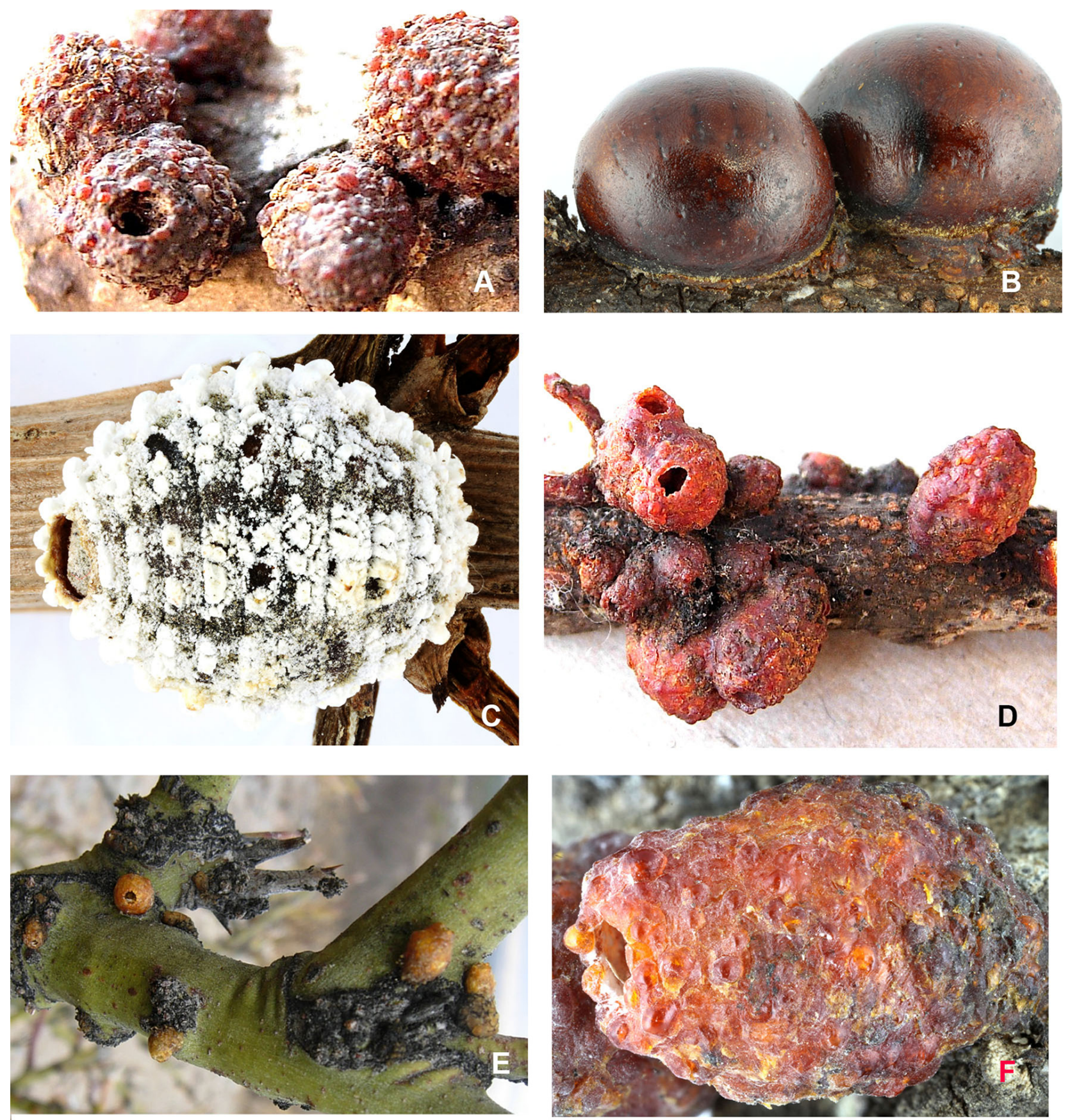

FIGURE 1. Tests or sclerotised derms of preadult females of South American Cryptokermesini on their host plants: A. Tests of Cryptokermes brasiliensis Hempel, Brazil, syntypes, USNM (photo by P.J. Gullan); B. Preadult derms of Mimosicerya hempeli (Cockerell), Brazil, MNHN (photo by I. Foldi); C. Preadult derm of Mimosicerya schraderae (Vayssière), Panama, syntype, MNHN (photo by I. Foldi); D. Tests of Neocoelostoma xerophila Hempel, Brazil, syntypes, USNM (photo by P.J. Gullan); E. Tests of N. xerophila, Argentina (photo by P.J. Gullan); F. Test of Paracoelostoma peruvianum Morrison, Peru, syntypes, USNM (photo by I. Foldi).

Adult female. Major morphological features such as a sclerotised zone on the head, presence or absence of mouthparts and degree of development of antennae and legs vary among females of the different species and genera. Cryptokermes and Mimosicerya have a large, sclerotised zone on the head, which extends onto the thorax. In contrast, the adult females of Neocoelostoma and Paracoelostoma lack a sclerotised zone anteriorly, but the anal area may become slightly sclerotised at maturity in Paracoelostoma. The antennae range from well developed in Neocoelostoma (11 segmented) and Paracoelostoma (5 or 6 segmented) to reduced to a group of setae in 
Cryptokermes and Mimosicerya. Mouthparts are present in Paracoelostoma, but absent in the other genera, although the apparent presence in Paracoelostoma may be due to retention of the preadult mouthparts in the adult cuticle. Legs range from well developed in Neocoelostoma to considerably reduced in Cryptokermes, Mimosicerya hempeli and Paracoelostoma and absent in M. mexicana and M. schraderae. The thoracic spiracles lack atrial pores but each spiracle has a cluster of perispiracular multilocular pores and a well-developed apodeme; the 7 pairs of abdominal spiracles each have atrial multilocular pores. The anal opening is usually apical to slightly dorsal; the anal tube is probably always membranous and, if a sclerotised ring of polygonal wax glands is present at the inner end, this may due to the preadult anal tube being retained within the tube of the adult. Multilocular pores mostly have a circular, oval, triangular or quadrate centre and various numbers of outer loculi. Hairs, hair-like setae, flagellate setae, spiniform setae and spines are present. Cicatrices and disc-like tubercles are absent.

Third-instar (preadult) female. Antennae 8 or 9 segmented in Neocoelostoma and Mimosicerya, 6 segmented in Paracoelostoma and either 3-7 segmented or reduced to a group of setae in Cryptokermes. Legs well developed in Mimosicerya but considerably reduced in size and/or structure in all other genera. Mouthparts always present. Thoracic spiracles lacking atrial pores but with numerous perispiracular multilocular pores; all 7 pairs of abdominal spiracles with atrial pores. Sclerotised anal plate large in Neocoelostoma and Paracoelostoma, but smaller and less complex in Cryptokermes and Mimosicerya. Anal tube with a band of polygonal wax pores at inner end and with a circle of pores on middle or distal part of tube in all genera except apparently Paracoelostoma. Multilocular pores numerous and mostly similar those of adult females. Hairs, hair-like setae, flagellate setae, spiniform setae and spines present. Cicatrices and disc-like tubercles with slightly domed centre present.

Second-instar nymph. Specimens of this instar were available for only two genera, Cryptokermes and Neocoelostoma, and it is not clear whether they are female or male. Antennae 5 segmented in Neocoelostoma and 6 segmented in Cryptokermes. Legs with 5 distinct segments, of normal development in Cryptokermes but leg structure reduced in Neocoelostoma. Thoracic spiracles lack atrial pores but have numerous perispiracular multilocular pores; all 7 pairs of abdominal spiracles with atrial pores. Anal tube with a sclerotised inner end and anal opening located at centre of a sclerotised area. Multilocular pores mostly with a circular, oval, triangular or quadrate centre and various numbers of outer loculi. Hairs, hair-like setae, flagellate setae, spiniform setae present. Cicatrices and disc-like tubercles always present.

First-instar nymph. Antennae 6 segmented with apical segment largest. Legs well developed, with a denticle and a pair of setose digitules on each claw. Thoracic spiracles each with 1-3 perispiracular pores; all 7 pairs of abdominal spiracles lack atrial pores, apart from Paracoelostoma which has one atrial pore in each spiracle. Anal tube well developed, with a band of polygonal pores at inner end; anal opening apical to subapical, surrounded either by spines, spiniform setae and pores (Cryptokermes and Mimosicerya) or by a sclerotised plate bearing setae and pores (Neocoelostoma and Paracoelostoma). Multilocular pores mostly with a circular, oval, triangular or quadrate centre and various numbers of outer loculi. Raised pores present around anal opening in Paracoelostoma. Derm covered with small hair-like setae, flagellate setae with a large, flat basal collar, and hairs with swollen bases; spines or spiniform setae present on posterior abdomen in Cryptokermes and Mimosicerya. Posterior abdomen with 2 pairs of long caudal setae in Neocoelostoma and Paracoelostoma, 2 pairs of long caudal and 2 pairs of long lateral setae present in Cryptokermes, and 3 pairs of long caudal and 1-6 pairs of long lateral setae found in Mimosicerya species. Cicatrices present on posterior ventral abdomen in an arc of 3, with one medially and 2 laterally in C. brasiliensis, Mimosicerya and Neocoelostoma, and a submedial longitudinal row of 6 cicatrices on each side of abdomen in Paracoelostoma. Disc-like tubercles present in Mimosicerya (toadstool shaped in side view), Cryptokermes and Neocoelostoma (discs with domed centre), but absent in Paracoelostoma.

Adult male. The adult males of two species were available: M. schraderae and N. xerophila. Antenna 10 segmented, each segment without nodes and setae not arranged in whorls. Ocelli dorsal to compound eyes. One or more posterior abdominal segments with paired caudal extensions. Collared setae either absent or with a shallow collar-like basal socket. Bifurcated setae either absent from all legs or present only on profemur. Claws with a pair of setose digitules. Apex of penial sheath divided (bifurcate) and broader anteriorly than posteriorly, and endophallus strongly setiferous. 


\section{Key to separate the tribes Llaveiini and Cryptokermesini}

1. Females secreting and developing within a test (Fig. 1A, D \& E) and/or the adult female pupillarial in the preadult exuviae (Fig. 1B \& C); second- and third-instar females usually with reduced legs and antennae; adult females lacking cicatrices; firstinstar nymphs with dorsal disc-like tubercles (except Paracoelostoma) but dorsal spines either confined to abdomen or absent Cryptokermesini

- $\quad$ Females not secreting a test and never pupillarial; second- and third-instar females always with well-developed legs and antennae; adult females with three or more cicatrices; first-instar nymphs with dorsal spines but lacking disc-like tubercles.

Llaveiini

\section{Key to genera of Cryptokermesini based on adult females}

1. Derm with a large sclerotised zone on head and thorax; antenna represented by a cluster of setae $\ldots \ldots \ldots \ldots \ldots . . .2$

- $\quad$ Derm without a large sclerotised zone on head and thorax; antenna with distinct segments . . . . . . . . . . . . . . 3

2. No test present, but adult retained inside sclerotised exuviae of preadult female; legs vestigial, strongly reduced and modified with segments indistinct, or legs absent; claw absent; spines present on sclerotised zone of head and thorax ...

.Mimosicerya Cockerell

- $\quad$ Developing and ovipositing within a heavily-walled test on host plant; legs strongly reduced, with claw clearly distinct; spines present around as well as on sclerotised zone of head and thorax . . . . . . . . . . . . . . . Cryptokermes Hempel

3. Developing within a thickly-walled test but exiting the test for oviposition elsewhere; antenna 11 segmented; legs fully developed; setae not densely clustered around anal opening; mouthparts absent . . . . . . . . . . . . . Neocoelostoma Hempel Developing and ovipositing within a thickly-walled test on host plant; antenna 5-6 segmented; legs with segments distinct but poorly developed; with a dense cluster of setae around anal opening; mouthparts present ......... Paracoelostoma Morrison

\section{Key to genera of Cryptokermesini based on preadult females}

1. Legs well developed, with length of tibia much more than twice its width $\ldots \ldots \ldots \ldots \ldots \ldots \ldots$. . . . . . . . . . . . .

- $\quad$ Legs reduced by shortening of all segments, with length of tibia less than twice its width $\ldots \ldots \ldots \ldots \ldots \ldots \ldots$

2. Antenna 8-9 segmented; anal opening surrounded by a "secretory unit" formed by a dense ring of elongate wax pores .....

....... Neocoelostoma

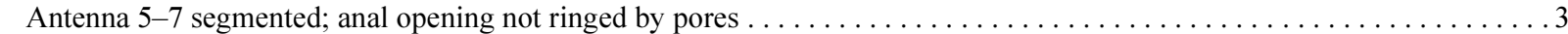

3. Spines present on dorsum and venter; posterior end of body with raised pores and with long flagellate setae around anal opening; disc-like tubercles with slightly domed centre and cicatrices numerous on both dorsum and venter .......Cryptokermes Spines absent; posterior end of body without raised pores, but with wide simple pores and rare, short hair-like setae; disc-like tubercles absent; cicatrices present only on venter, but cicatrix-like structures present on dorsum and venter

Paracoelostoma

\section{Key to genera of Cryptokermesini based on first-instar nymphs}

1. Derm with a sclerotised area on posterior end of abdomen; with 2 pairs of long caudal setae but no long lateral setae .....2

- Derm without a sclerotised area on posterior end of abdomen; with 2 or 3 pairs of long caudal setae plus several long lateral

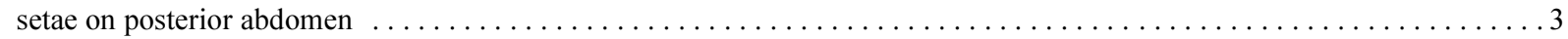

2. Sclerotised posterior area large with anterior dorsal edge triangular and with a band of raised pores around anal opening; with 6 cicatrices in a longitudinal submedial line on each side of venter (12 in total); abdominal spiracles each with one atrial pore

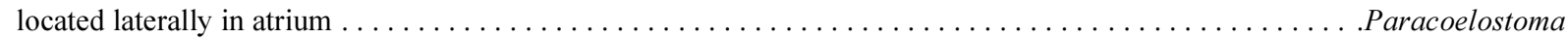

- $\quad$ Sclerotised posterior area circular, with a single ring of pores around anal opening; with 3 cicatrices in a transverse line on medial posterior venter ( 3 in total); abdominal spiracles without atrial pores . . . . . . . . . . . . . . Neoceolostoma

3. Disc-like tubercles in side view appearing as a flat disc with a conical, domed centre; with 2 pairs of long caudal setae and 2 pairs of long lateral setae; spiniform setae present around anal opening only . . . . . . . . . . . . Cryptokermes Disc-like tubercles in side view toadstool-shaped with a domed cap; with 3 pairs of long caudal setae and 1-6 pairs of long lateral abdominal setae; spines present either on posterior abdomen or just around anal opening. . . . . . . . . . Mimosicerya 


\section{Descriptions of genera and species}

\section{Cryptokermes Hempel}

Cryptokermes Hempel, 1900: 398. Type species: Cryptokermes brasiliensis Hempel, by monotypy and original designation. Cryptokermes Hempel; Morrison, 1928: 100.

This genus was erected by Hempel (1990) for C. brasiliensis collected from a species of Schinus (Anacardiaceae) at Poços de Caldas in the state of Minas Gerais, Brazil. Subsequently, three more species, all from Mexico, were added to the genus: C. mexicanus Morrison collected from Mimosa (Fabaceae) (Morrison 1927), C. mimosae Foldi also from Mimosa (Foldi, 1995, 2011) and C. oaxaensis Foldi from Prosopis (Fabaceae) (Foldi, 2011). However, after careful examination of published descriptions and specimens of $C$. mexicanus from the two type localities, we have determined that it is a species of Mimosicerya and this species is discussed further under that genus. Also Cryptokermes mimosae Foldi does not fit the present morphological concept of Cryptokermes or any other named genus and is excluded from this revision pending further study of its relationships, and is not transferred to Cryptokermesini. The type species, $C$. brasiliensis is redescribed below but, because $C$. oaxacaensis was described and illustrated recently by Foldi (2011), it is not dealt with again here. In the generic diagnosis below, the features of the second- and first-instar nymphs are based only on $C$. brasilensis as these stages are not known for $C$. oaxacaensis.

Generic diagnosis. All stages live within a test on twigs or stems of the host plant; the adult female remains within the test to oviposit.

Adult female (based on C. brasiliensis and C. oaxacaensis). Enclosed within a spherical test; mostly in groups on twigs and stems, each group usually with 2-10 individuals. Test hard but brittle, with surface rough, and with an orifice about $1 \mathrm{~mm}$ in diameter, in position of anal opening. Body broadly oval, almost circular, with derm membranous apart from anterior, which is strongly sclerotised, mainly on dorsum; this sclerotised zone includes antennae and eyespots and bears spines and a few setae; adjacent unsclerotised derm densely covered by spines, some multilocular pores and few slender setae. Antennae each a flat structure or a small tubercle bearing a group of setae of various sizes and, in C. brasiliensis, also with 2 circular sensilla. Mouthparts absent. Legs of reduced size, segments not discernable. Thoracic spiracles each with numerous perispiracular multilocular pores. Abdominal spiracles numbering 7 pairs, each with atrial pores. Vulvar opening apparently membranous. Anal opening apical to subapical; anal tube membranous, with adult female often retaining anal tube of preadult stage. Dorsal and ventral multilocular pores each with a circular, bilocular or triangular centre. Long hair-like setae present in a transverse row on each segment except at anterior and posterior ends; shorter, thick, spiniform or slender hair-like setae mostly present on abdomen, scattered. Spines present on sclerotised zone of head and thorax, also in a band on adjacent derm. Cicatrices and disc-like tubercles absent.

Third-instar (preadult) female (based on both C. brasiliensis and C. oaxacaensis). Body broadly oval, almost circular, inside a test (as in adult female). Derm membranous, but sclerotised in a circular area around anal opening. Antenna short, indistinctly 3-7 segmented or reduced to a group of setae. Mouthparts present, with labium 3 segmented. Legs reduced, but segments distinct. Thoracic spiracles each with numerous perispiracular pores. Abdominal spiracles numbering 7 pairs, each with a few to numerous atrial pores. Anal opening with a broad, sclerotised margin, opening in a sclerotised area, surrounded by several rings of pores, each with a very wide rim. Anal tube with polygonal wax pores at inner end and a circle of multilocular pores more distally. Dorsal and ventral derm covered in abundant pores and setae of various types, plus spines, cicatrices and disc-like tubercles. Dorsal and ventral multilocular pores present, each with a central loculus either circular, bilocular or trilocular; raised pores present only on dorsum. Various setae present; stout, enlarged conical spines restricted to posterior end, particularly around anal opening. Cicatrices and dorsal disc-like tubercles scattered.

Second-instar nymph (based on C. brasiliensis only). Body elongate-oval, with anal area slightly dorsal and sclerotized, bearing multilocular pores, spines and long flagellate setae. Antenna 6 segmented. Mouthparts present, with labium 3 segmented. Legs fully developed but with short, stout segments. Thoracic spiracles small, each with perispiracular pores. Abdominal spiracles each with several atrial pores. Anal opening apical, at centre of a sclerotised anal plate. Anal tube with a band of polygonal wax pores at inner end and a single circle of pores at mid length. Dorsal and ventral multilocular pores mostly with a circular centre, but sometimes with a triangular or quadrate centre. Dorsal hair-like setae short; flagellate setae and hairs scattered; stout spine-like setae present near 
coxae, and a few present on posterior abdominal segments. Disc-like tubercles, each with a domed centre, and cicatrices scattered on head and thorax and present in a single transverse row on each abdominal segment.

First-instar nymph (based on C. brasiliensis only). Body elongate-oval. Antenna 6 segmented. Clypeolabral shield and labium well developed. Legs well developed, slender; trochanter with 2 campaniform sensilla on each side; claw long and slender with a single denticle near apex; claw digitules setose. Thoracic spiracles each with a single perispiracular pore. Abdominal spiracles numbering 7 pairs; atria without pores. Anal opening surrounded by a ring of pores, spiniform setae and hair-like setae. Anal tube conspicious, inner end with polygonal wax pores and a circle of pores at opening. Dorsal and ventral multilocular pores, each with 3-6 central loculi and 8-16 outer loculi, in a scattered row among setae on each segment. Short stiff setae on margins and longest hair-like setae in a row across each dorsal and ventral body segment. Enlarged, stout, conical spiniform setae surrounding anal opening. Posterior end of body with 2 pairs of long caudal setae and 2 pairs of long lateral setae. Cicatrices circular, 3 in number, in a medial transverse line on posterior ventral abdomen. Dorsal disc-like tubercles with conical domed centre, present across all segments of body.

\section{Cryptokermes brasiliensis Hempel}

Cryptokermes brasiliensis Hempel, 1900: 398.

Cryptokermes brasiliensis; Morrison, 1928: 100.

According to Ben-Dov (2005), there are supposed to be Hempel type specimens of this species in the Instituto Biologico de São Paulo. One of us (I. Foldi) tried to examine these in November 1985 during a visit to Brazil. Although accompanied by Dr Saulo J. Soria, entomologist at EMBRAPA in Brazil, it was not possible to examine or borrow material from the Hempel collection at Instituto Biologico de São Paulo during their time in São Paulo. In his original description, Hempel (1900) stated that he sent specimens of this insect to T.D.A. Cockerell for his opinion. This explains how material of $C$. brasiliensis from the type locality came to be deposited in the USNM (see below). We have not designated a lectotype because we have not examined Hempel's type material housed in Brazil.

Type material examined. BRAZIL: Syntypes: remains of dry females and nymphs ex tests, in 2 boxes with labels: "16. TYPE. /Cryptokermes brasiliensis / Hempel" [handwritten], and "16. /Cryptokermes brasiliensis/ Hempel. Type. / Poços de Caldas, Minas." [typed], ex USNM dry collection; 6 slides each with an adult female and a third-instar exuviae, 2 slides each with remains of an adult female, and 11 slides each with 20 or more first-instar nymphs except one slide with 1 nymph, all prepared from above dry material by P.J. Gullan in 2009 (USNM). Also 2 slides each with remains of 1 adult female and 1 other slide with 2 first-instar nymphs +4 embryoes, labelled: "Cryptokermes / brasiliensis / Hemp. / Poços de Caldas / Minas, Brazil / 1900" (USNM); 1 slide of adult female and 1 slide with remains of 2 third-instar females, labelled: "Cryptokermes / brasiliensis / Hempel. / On $\underline{\text { Schinus / }}$ Poços de Caldas / F. Rinas / 1900 / Type" (USNM); 1 slide with adult female ex test, from box with labels "Type" and "Poços de Caldas, Minas, Cotypes", slide prepared by I. Foldi in 1990 (MNHN).

Other material examined. BRAZIL: 1 slide with 6 first-instar nymphs, Poços de Caldas, Sept. 4, 1899. H. von Ihering (USNM); 1 slide with adult female and 1 slide with an adult female and a third-instar female, Paraná, Mata Atlantica, on Schinus, 9. xi. 1985, coll. I. Foldi, prepared 1990 (MNHN).

Adult female (Fig. 2). Unmounted material. Adult female enclosed in a spherical test (Fig. 1A) about 6-8 $\mathrm{mm}$ in diameter, dark brown, with a rough external surface and an internal wall covered by a coating of white wax secretion, and with an orifice about $1 \mathrm{~mm}$ in diameter in position of female's anal opening.

Mounted specimens ( $\mathrm{n}=7$ ). Body broadly oval, 8.0-8.5 mm long, 6.3-6.6 mm wide; membranous except for a large, strongly sclerotised, more-or-less circular area on dorsum and partly on venter of head, with an irregular contour, about $1.7-1.8 \mathrm{~mm}$ in diameter, including antennae and eyespots, and bearing spines (Fig. 2B), slender setae (Fig. 2D) and multilocular pores (Fig. 2C). Sclerotised zone surrounded by an unsclerotised band, about 350-400 $\mu \mathrm{m}$ wide, densely covered by stout, straight or curved spines; each spine usually 25-30 $\mu \mathrm{m}$ long, rarely up to $60 \mu \mathrm{m}$, with an acute apex and a broadened base (Fig. 2B); short slender setae, each about $14 \mu \mathrm{m}$ long, rare; also other setae, each 25-30 $\mu \mathrm{m}$ long, sparsely scattered (Fig. 2D). Antennae each reduced to a small circular setose tubercle and located in a small cavity (Fig. 2A), usually $125-170 \mu \mathrm{m}$ wide with a thick rim; each antenna about 70 $\mu \mathrm{m}$ in diameter, bearing a few short stout spinose setae, each 6-7 $\mu \mathrm{m}$ long, and 4-5 thick setae, each about 30-50 
$\mu \mathrm{m}$ long; also 2 small sensory organs present on some individuals; number of short or long setae and sensory organs highly variable among material examined. Eyespot circular. Mouthparts absent. Legs (Fig. 2M) reduced in size and indistinctly segmented, 330-370 $\mu \mathrm{m}$ long, with numerous setae, each 25-100 $\mu \mathrm{m}$ long, scattered over whole length of legs; trochanteral seta (ts) about $185 \mu \mathrm{m}$ long; claw well developed, $80-90 \mu \mathrm{m}$ long, with a serrate edge and setose digitules. Thoracic spiracles (Fig. 2K) each with a large peritreme, $170 \mu \mathrm{m}$ wide, and 50-60 perispiracular multilocular pores. Abdominal spiracles (Fig. 2F) numbering 7 pairs, each atrium with atrial pores; spiracles ranging from $80 \mu \mathrm{m}$ in diameter anteriorly to $40 \mu \mathrm{m}$ posteriorly, and with number of atrial pores reducing from 20-35 per anterior atrium to 2-3 posteriorly; each atrium connected to trachea via a short sclerotised tube. Vulvar opening membranous, difficult to detect. Anal opening apical; anal tube simple and delicate; most adult females retain preadult anal tube (Fig $2 \mathrm{~N}$ ).

Dorsum. Multilocular pores, each $10 \mu \mathrm{m}$ in diameter and mostly with an oval, circular or triangular centre and with 10-16 outer loculi, scattered throughout body, usually in a row 1-2 pores wide across each abdominal segment (Figs. 2C, E, I). Slender hair-like setae (Fig. 2D), each 28-33 $\mu \mathrm{m}$ long, scattered throughout head and thorax and across each abdominal segment; stouter spinose setae (Fig. 2G), each 50-60 $\mu \mathrm{m}$ long, sparsely distributed; longest hair-like setae in medial and submedial longitudinal lines (Fig. 1H). Cicatrices and disc-like tubercles absent.

Venter. Multilocular pores mostly similar to those on dorsum but perhaps slightly smaller, each about $9 \mu \mathrm{m}$ wide, distributed in transverse bands $4-5$ pores wide on anterior abdominal segments but up 10-14 pores wide more posteriorly where pores mixed with (i) hair-like setae, each seta 30-90 $\mu \mathrm{m}$ long (Fig. 2H), and (ii) hairs (Fig. $2 \mathrm{~J}$ ), usually about $38 \mu \mathrm{m}$ long. Setae and (particularly) pores more numerous than on dorsum. Stout spiniform setae (Fig. 2G), each 21-23 $\mu \mathrm{m}$ long with a large base and acute apex, scattered; short, stout spines (Fig. 2L) present on medial area of thorax; curved spines (Fig. 2B) present on head in sclerotised area. Short slender setae, similar to those on dorsum (Fig. 2D), each 25-35 $\mu \mathrm{m}$ long, found on head and thorax, and across abdominal segments, scattered; longest hair-like setae (Fig. $2 \mathrm{H}$ ) as on dorsum, present in medial and submedial longitudinal lines. Hairs with expanded bases (Fig. 2J) rare. Cicatrices and disc-like tubercles absent.

Third-instar (preadult) female (Fig. 3). Unmounted material. Living within a test, as described above for adult female. Derm of live preadult female light yellow according to Hempel (1900), who mistakenly described the third-instar female as the adult.

Mounted specimens ( $\mathrm{n}=6$ ). Body broadly oval, globular, 6-8 $\mathrm{mm}$ long, 5-7 mm wide; derm membranous except posteriorly where apex becomes progressively more heavily sclerotised in an approximately circular area surrounding anal opening (Fig. 3K). Antenna (Fig. 3A) short, 210-230 $\mu \mathrm{m}$ long, indistinctly 3-6 segmented; scape $120 \mu \mathrm{m}$ wide, apical segment 75-78 $\mu \mathrm{m}$ long, 70-73 $\mu \mathrm{m}$ wide. Each antennal segment with a few setae, each about 20-35 $\mu \mathrm{m}$ long; apical segment with about 6-8 fleshy setae, each 40-50 $\mu \mathrm{m}$ long, plus about 16-18 flagellate setae, each 50-60 $\mu \mathrm{m}$ long. Eyespot on a conical sclerotised base, situated lateral to antenna. Clypeolabral shield well developed, 800-850 $\mu \mathrm{m}$ long. Labium about $500 \mu \mathrm{m}$ long, conical, 3 segmented; apical segment with 6-8 sensory setae. Legs short (Fig. 3N), each about 280-300 $\mu \mathrm{m}$ long, and strongly modified with segmentation weakly distinct; trochanter with one campaniform sensillum on each side plus a trochanteral seta about $170 \mu \mathrm{m}$ long; tibia and tarsus weakly distinct but apparently occasionally fused, at most about 90-95 $\mu \mathrm{m}$ long, tarsus with a cluster of short setae ventrally near claw, each seta 20-30 $\mu \mathrm{m}$ long (Fig. 3N); claw 45-50 $\mu \mathrm{m}$ long with 2 or 3 denticles and 1 pair of long (about $35 \mu \mathrm{m}$ ) setose digitules. Thoracic spiracles (Fig. 3O), each with peritreme 60-65 $\mu \mathrm{m}$ wide and about 35-40 perispiracular multilocular pores and a strong apodeme. Abdominal spiracles (Fig. 3E) numbering 7 pairs; each spiracle consisting of an outer membranous atrium, about $50 \mu \mathrm{m}$ long, $45-50 \mu \mathrm{m}$ wide, and a sclerotised inner atrium up to $50 \mu \mathrm{m}$ long, $70 \mu \mathrm{m}$ wide; posteriormost pair of spiracles smallest; each outer atrium with about 21-35 multilocular pores except most posterior atria with fewer pores. Anal opening surrounded by a sclerotised area (Fig. 3K), approximately 1.0-1.2 mm wide, bearing raised, wide-rimmed multilocular pores, spinelike tubercles and long setae, as follows: (i) multilocular pores (Fig. 3M), each $12-15 \mu \mathrm{m}$ wide, mostly with a triangular or quadrilocular (rarely quinquelocular) centre and 10-16 small outer loculi, located in a sunken centre on raised sclerotised derm; (ii) spine-like tubercles (Fig. 3L), each $25 \mu \mathrm{m}$ long, $15 \mu \mathrm{m}$ wide, that, when viewed from above, appear as a pore with a single large central loculus; distributed in a ring surrounding raised pores; and (iii) about 12 flagellate setae with an expanded base (Fig. 3J), each seta 60-70 $\mu \mathrm{m}$ long, surrounding anal opening and located among pores. Anal tube (Fig. 3I) 630-650 $\mu \mathrm{m}$ long, with a band of polygonal wax pores at inner end and a circle of multilocular pores, $1-2 \mu \mathrm{m}$ wide, more distally. 


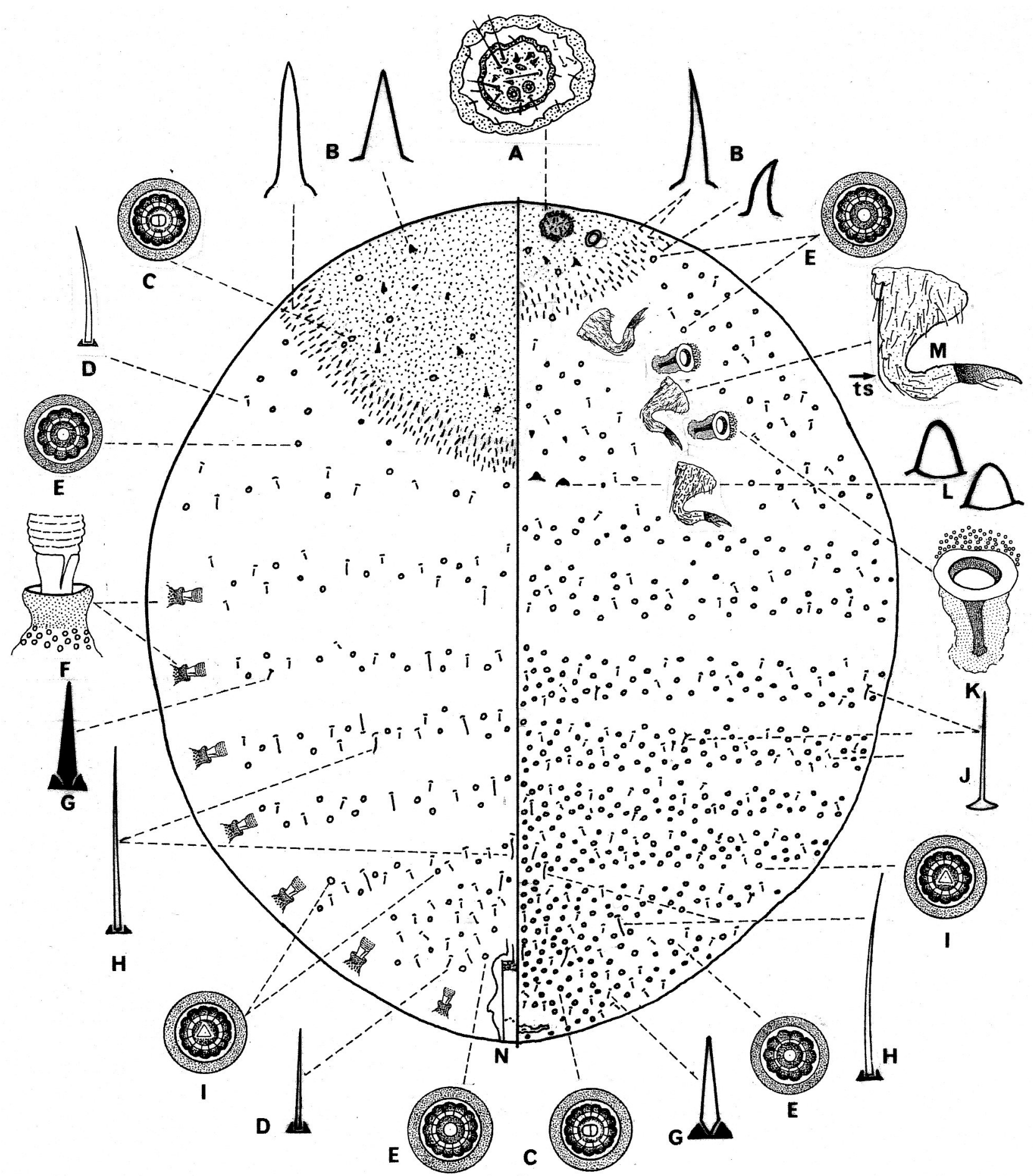

FIGURE 2. Cryptokermes brasiliensis Hempel. Adult female. A. antenna; B. spines; C. multilocular pore with bilocular centre; D. flagellate setae, on dorsum and venter; E. multilocular pore with circular centre; F. abdominal spiracle; G. spiniform seta; H. slender hair-like seta; I. multiocular pore with triangular centre; J. hair; K. metathoracic spiracle; L. short, wide spines; M. mesothoracic leg; N. anal tube containing that of preadult.

Dorsum. Multilocular pores (Fig. 3B), each $10 \mu \mathrm{m}$ in diameter with a circular or triangular centre and 12-16 outer loculi, distributed in an irregular transverse row or band on each body segment. Small quadrilocular pores (Fig. 3G) sparsely scattered. Stout, enlarged conical spines (Fig. 3H), each 20-25 $\mu \mathrm{m}$ long, scattered on abdomen, but most abundant posteriorly. Hair-like setae (Fig. 3F) with conical basal collars, of various sizes: shorter setae 15-25 $\mu \mathrm{m}$ long, either thin or thick, with an enlarged apex, or longer and thicker setae, $45-55 \mu \mathrm{m}$ long, scattered on all segments. Cicatrices (Fig. 3D), each $12-30 \mu \mathrm{m}$ in diameter, in a transverse row 1 or 2 cicatrices wide on each 
body segment. Disc-like tubercles (Fig. 3C), each 7-8 $\mu \mathrm{m}$ in diameter with a thick rim and a slightly domed centre, scattered on head and thorax, and present in transverse segmental rows on abdomen.

Venter. Multilocular pores (Fig. 3B), similar to those on dorsum, scattered across each body segment. Small quadrilocular pores (Fig. 3G) sparsely scattered. Stout conical spines (Fig. 3H) as on dorsum, scattered across abdomen, but most abundant posteriorly. Hair-like setae (Fig. 3F) as on dorsum, each 45-55 $\mu \mathrm{m}$ long, most numerous on medial and submedial area. Hairs with an expanded base (Fig. 3F) rather rare. Cicatrices (Fig. 3D), each $12-30 \mu \mathrm{m}$ in diameter, in a transverse row 1 or 2 cicatrices wide across each abdominal segment. Disc-like tubercles (Fig. 3C) similar to those on dorsum, each 7-8 $\mu \mathrm{m}$ in diameter with a thick rim and a slightly domed centre, scattered on head and thorax, most numerous across abdominal segments.

Second-instar nymph (Fig. 4). Mounted specimens ( $\mathrm{n}=7$ ). Body ovoid elongate, 2.2-2.9 mm long, 1.4-2.1 $\mathrm{mm}$ wide; derm membranous throughout but dorsum with a slightly sclerotised area around anal opening. Antenna (Fig. 4A) 6 segmented, 310-330 $\mu \mathrm{m}$ long; each segment with about 3 or 4 setae, each 10-15 $\mu \mathrm{m}$ long; apical segment $80 \mu \mathrm{m}$ long, $90 \mu \mathrm{m}$ wide, with 3 or 4 fleshy setae and 4 slender setae. Clypeolabral shield 590-700 $\mu \mathrm{m}$ long; labium 3 segmented, about 310-350 $\mu \mathrm{m}$ long, apex with about 8 setae. Eyespot conical, situated lateral to antennal base. Legs short (Fig. 4O), about 400-440 $\mu \mathrm{m}$ long, each segment stout with few to several setae, each 15-20 $\mu \mathrm{m}$ long; trochanter with a long seta about 110-120 $\mu \mathrm{m}$ and 2 campaniform sensilla on each side; trochanter + femur 240-248 $\mu \mathrm{m}$ long, femur 120-130 $\mu \mathrm{m}$ wide; tibia 110-115 $\mu \mathrm{m}$ long, 75-80 $\mu \mathrm{m}$ wide; tarsus 55-60 $\mu \mathrm{m}$ long, 65-68 $\mu \mathrm{m}$ wide; claw short, robust, about $20 \mu \mathrm{m}$ long, with one pair of setose digitules. Thoracic spiracles (Fig. 4P) small, each peritreme 32-35 $\mu \mathrm{m}$ wide with a cluster of about 11-14 multilocular perispiracular pores and with a well-developed apodeme. Abdominal spiracles (Fig. 4N) each with small atrium, 35-40 $\mu \mathrm{m}$ long, 22-28 $\mu \mathrm{m}$ wide; each atrium with an internal sclerotised part, about 18-20 $\mu \mathrm{m}$ long, and an external membranous part, about 18-20 $\mu \mathrm{m}$ long, with 4-6 atrial pores; posteriormost pair of spiracles smallest and with fewest pores. Anal opening apical, about $80 \mu \mathrm{m}$ in diameter, in centre of a sclerotised anal plate (Fig. $4 \mathrm{~K}$ ), 640-680 $\mu \mathrm{m}$ wide, bearing pores, setae and spines, as follows: (i) raised and wide-rimmed multilocular pores (Fig. 4L), each 14-16 $\mu \mathrm{m}$ in diameter, densely distributed around anal opening and scattered elsewhere on anal plate; (ii) setae, mostly hair-like, each 50-130 $\mu \mathrm{m}$ long, mixed with few flagellate setae; and (iii) stout spines (Fig. 4H), each 15-16 $\mu \mathrm{m}$ long, 11-13 $\mu \mathrm{m}$ wide, densely scattered. Anal tube (Fig. 4I) 400-420 $\mu \mathrm{m}$ long, 82-86 $\mu \mathrm{m}$ wide, with a band of polygonal wax pores at inner end and a single circle of pores at mid length.

Dorsum. Multilocular pores (Figs 4B, G), each 10-11 $\mu \mathrm{m}$ in diameter with a triangular, quadrate or mostly circular centre and 8-12 outer loculi, scattered on head and thorax and distributed in lines 1-2 pores wide across each body segment. Raised pores (Fig. 4L) present on sclerotised posterior area. Stout spine-like setae (Fig. 4H), about $25 \mu \mathrm{m}$ long, very few, scattered, mostly on posterior segments. Hair-like setae short (Fig. 4F), mostly 10-25 $\mu \mathrm{m}$ long, often with a wide socket and collar, scattered throughout; some longer, up to 40-85 $\mu \mathrm{m}$ long, rare. Flagellate setae (Fig. 4E), each 25-40 $\mu \mathrm{m}$ long, scattered. Cicatrices (Figs 4D), each 16-22 $\mu \mathrm{m}$ in diameter, scattered on head and thorax, and in transverse rows on each abdominal segment. Disc-like tubercles (Fig. 4C), $10-11 \mu \mathrm{m}$ in diameter, domed in centre, scattered throughout head and thorax and present in lines 1-2 tubercles wide across abdominal segments.

Venter. Multilocular pores (Figs. 4B, R), each 10-11 $\mu \mathrm{m}$ in diameter with a circular, triangular or quadrate centre and 6-10 outer loculi, scattered on head and thorax, and across each abdominal segment. A few stout spinelike setae (Figs 4H), each 16-19 $\mu \mathrm{m}$ long, on metathorax and posterior abdominal segments. Hair-like setae (Fig. $4 \mathrm{~F}$ ), each 55-135 $\mu \mathrm{m}$ long, and short flagellate setae (Fig. 4E), each 16-22 $\mu \mathrm{m}$ long, scattered on all body segments. Cicatrices (Fig. 4D), 18-30 $\mu \mathrm{m}$ in diameter, in an irregular transverse row on each abdominal segment, fewer on head and thorax. Disc-like tubercles (Fig. 4C), each 10-12 $\mu \mathrm{m}$ in diameter and domed in centre as on dorsum, scattered on head and thorax and present across each abdominal segment.

First-instar nymph (Fig. 5). Mounted specimens ( $\mathrm{n}=8$ ). Body elongate, 1000-1100 $\mu \mathrm{m}$ long, 310-320 $\mu \mathrm{m}$ wide. Antenna 6 segmented, 410-420 $\mu \mathrm{m}$ long; a campaniform sensillum present on apex of pedicel; apical segment $125 \mu \mathrm{m}$ long, $45 \mu \mathrm{m}$ wide, comprising nearly a third of total length of antenna, with 4 or 5 fleshy setae, each 35-55 $\mu \mathrm{m}$ long, and about 6 flagellate setae, each 75-110 $\mu \mathrm{m}$ long. Eyespot conical, located at base of antenna. Clypeolabral shield 300-330 $\mu \mathrm{m}$ long; labium 3 segmented, about 190-210 $\mu \mathrm{m}$ long; apical segment of labium with about 6-8 stout setae. Legs well developed, each with a large apodeme. Metathoracic leg: coxa 80-84 $\mu \mathrm{m}$ long; trochanter + femur 210-216 $\mu \mathrm{m}$ long; femur 50-54 $\mu \mathrm{m}$ wide; trochanter with 2 campaniform sensilla and a trochanteral seta 110-118 $\mu \mathrm{m}$ long; tibia $250-257 \mu \mathrm{m}$ long, $35 \mu \mathrm{m}$ wide; tarsus 180-190 $\mu \mathrm{m}$ long, $35 \mu \mathrm{m}$ wide; 


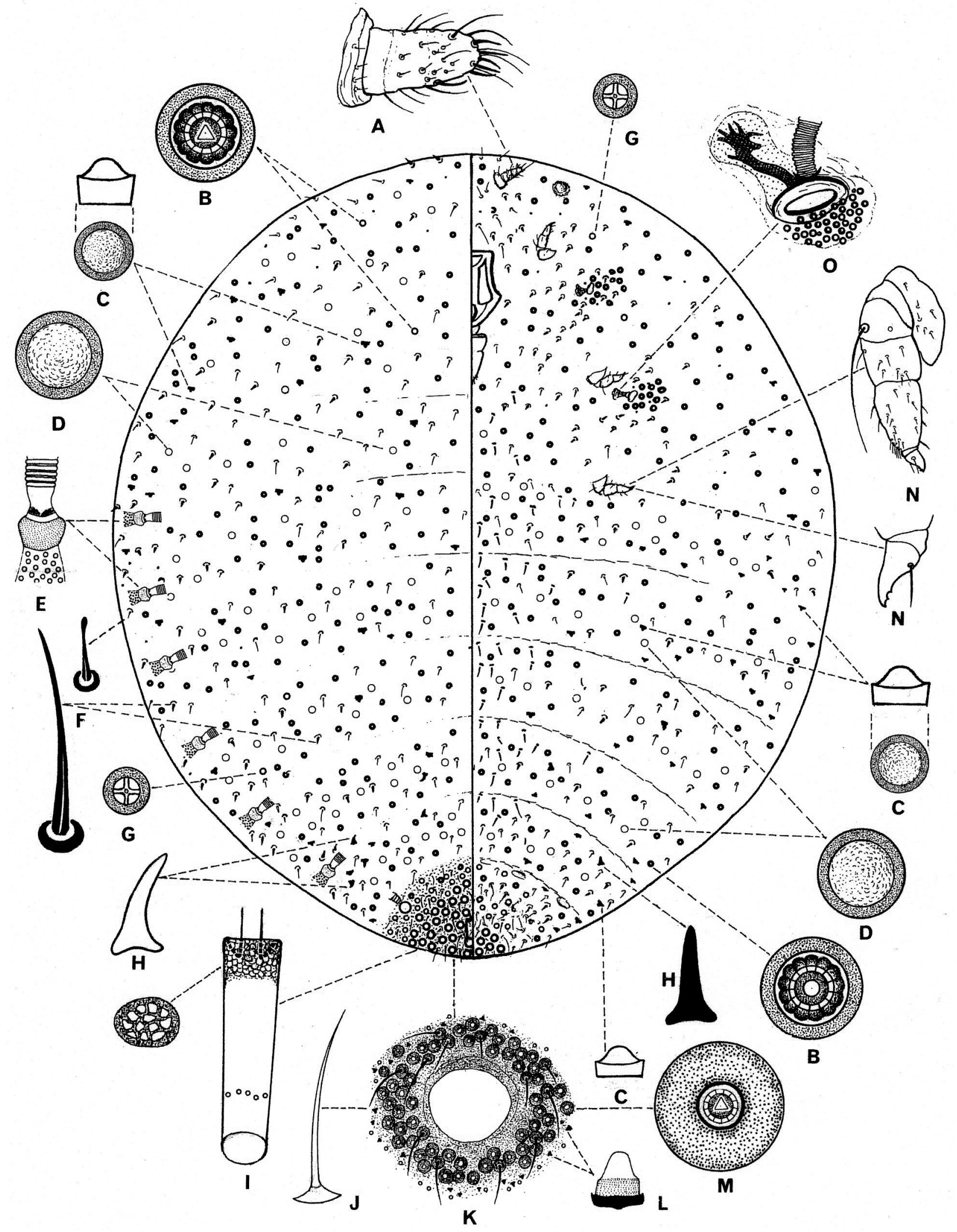

FIGURE 3. Cryptokermes brasiliensis Hempel. Third-instar female (preadult). A. antenna; B. multilocular pore with triangular or circular centre; C. disc-like tubercle with domed centre; D. cicatrix; E. abdominal spiracle; F. short and long hair-like setae, sometimes with enlarged apex; G. small cruciform pore; H. stout, curved spine; I. anal tube with polygonal wax glands at inner end and a circle of multilocular pores distally; J. flagellate seta with expanded base; K. sclerotised area with setae and pores around anal opening; L. spine-like tubercle in side view, but if viewed from above appearing as a pore with a single central loculus; M. raised, wide-rimmed multilocular pore; N. metathoracic leg with detail of claw; O. metathoracic spiracle with a cluster of perispiracular multilocular pores. 


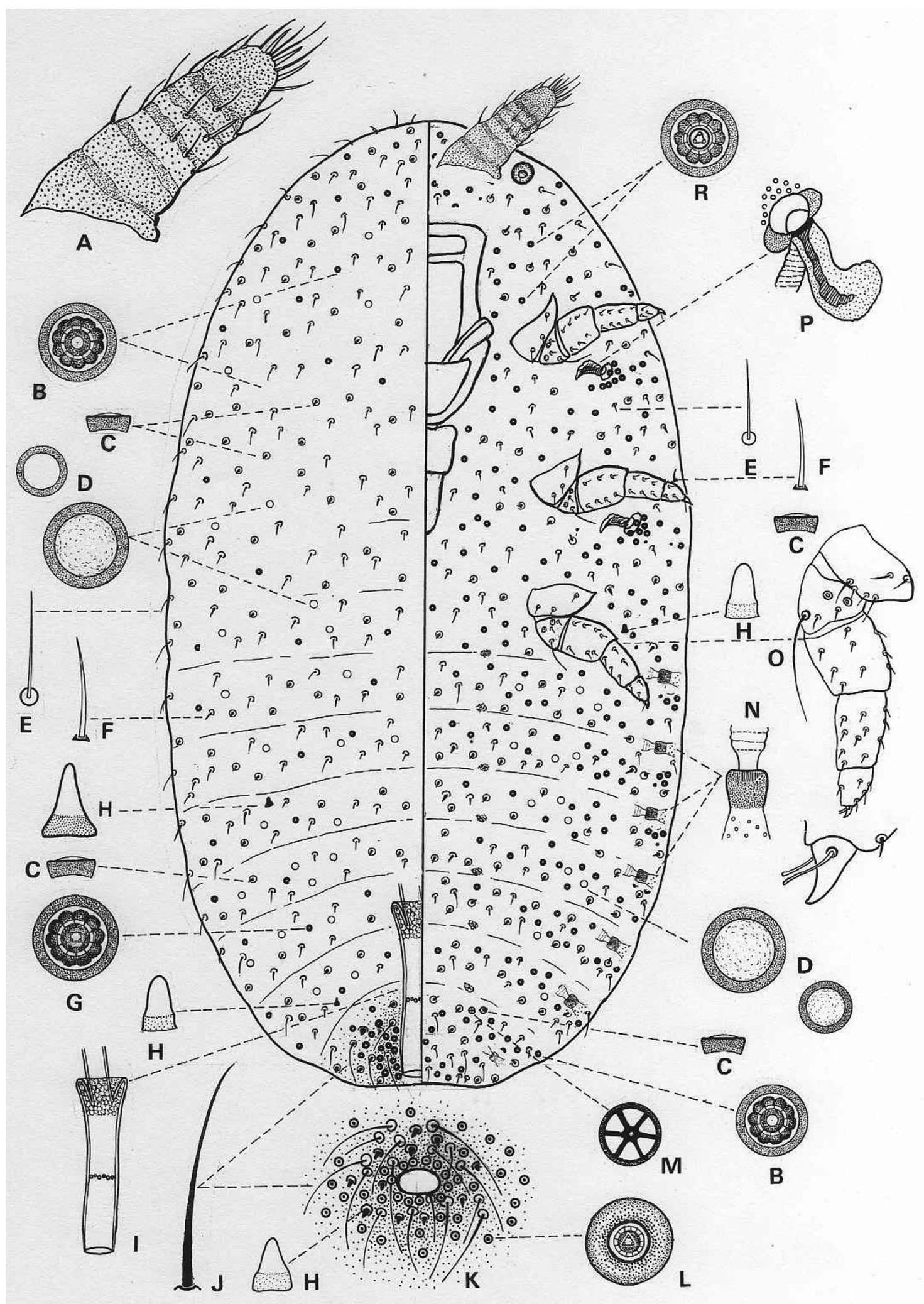

FIGURE 4. Cryptokermes brasiliensis Hempel. Second-instar nymph. A. antenna; B. multilocular pore with circular centre and 10 outer loculi; C. disc-like tubercle in side view; D. dorsal cicatrices ; E. slender flagellate seta; F. short hair-like seta; G. multilocular pore with quadrate centre and 10 outer loculi; H. spine-like setae of various sizes; I. anal tube with polygonal wax glands at inner end and pores at middle; J. long flagellate seta around anal opening; K. sclerotised circular area around anal opening; L. raised, wide-rimmed multilocular pore; M. rare 6-locular pore; N. abdominal spiracle; O. metathoracic leg with detail of claw; P. mesothoracic spiracle with a cluster of perispiracular multilocular pores; R. multilocular pore with triangular centre and 10 outer loculi. 


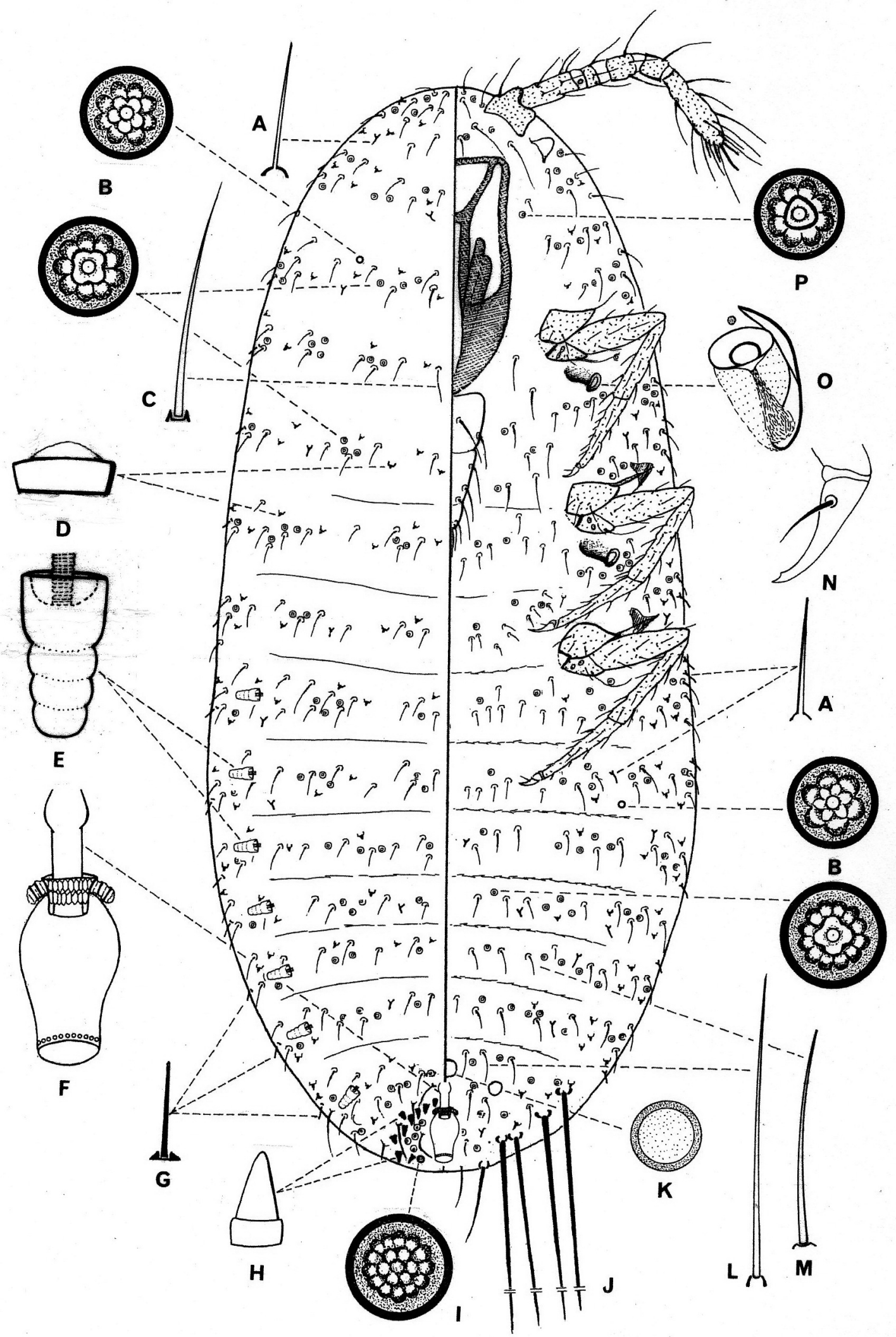

FIGURE 5. Cryptokermes brasiliensis Hempel. First-instar nymph. A. hair; B. multilocular pores with 4 or 5 central loculi; C. long dorsal hair-like seta; D. disc-like tubercle; E. abdominal spiracle; F. anal tube with polygonal wax glands at inner end and pores distally; G. short hair-like seta; H \& I. stout spinose setae (H) and multilocular pores (I) surrounding anal opening; J. 4 pairs of long caudal setae; K. cicatrix; L. long hair-like seta; M. flagellate seta; N. claw with denticle; O. mesothoracic spiracle; P. multilocular pore with triangular centre. 
claw (Fig. 5N) about 35-37 $\mu \mathrm{m}$ long, apex with a denticle and a pair of setose digitules. Thoracic spiracles (Fig. $5 \mathrm{O}$ ) each with a short atrium, about $25 \mu \mathrm{m}$ wide, with broad apodeme and a single perispiracular multilocular pore. Abdominal spiracles (Fig. 5E) numbering 7 pairs, each with an elongate tubular atrium about $18-20 \mu \mathrm{m}$ deep, bearing 3 or 4 circular constrictions but no pores; widest internal part about 9-10 $\mu \mathrm{m}$ in diameter, reducing to 5-6 $\mu \mathrm{m}$ towards external opening. Anal opening apical, $40-50 \mu \mathrm{m}$ in diameter, surrounded by a circle of about 16-18 of multilocular pores (Fig. 5I), plus a circle of hair-like setae, each 55-125 $\mu \mathrm{m}$ long, and clusters of stout, short conical spiniform setae (Fig. 5H), about 11-12 $\mu \mathrm{m}$ long and 5-7 $\mu \mathrm{m}$ wide at base. Anal tube (Fig. 5F) elongate with a band of polygonal wax pores at inner end and a single circle of pores distally.

Dorsum. Multilocular pores (Fig. 5B), each 10-11 $\mu \mathrm{m}$ in diameter, with either 5 central and 8 outer loculi or with a quadrate centre with 12 outer loculi, distributed in an irregular transverse row of about 6-8 pores on each segment. Multilocular pores with 6 or 7 central loculi and 12-14 outer loculi (Fig. 5I), scattered on posterior segments. Hair-like setae (Fig. 5C), each 55-135 $\mu \mathrm{m}$ long, usually with 8-11 in an irregular transverse row on each segment. Short, stiff hair-like setae (Fig. 5G), each about 10-20 $\mu \mathrm{m}$ long, along margin. Hairs (Fig. 5A) sparsely scattered throughout. Cicatrices absent. Disc-like tubercles (Fig. 5D), each 8-9 $\mu \mathrm{m}$ in diameter with a thick rim and a conical domed centre, scattered throughout.

Venter. Multilocular pores (Fig. 5P), each 10-11 $\mu \mathrm{m}$ in diameter with a triangular centre and 8 outer loculi, on head and thorax; also pores with either 4 or 5 central loculi and 6 outer loculi or with a quadrate centre and 12 outer loculi (Fig. 5B), in a transverse row across each abdominal segment, mixed with short hair-like setae (Fig. 5M), each 25-40 $\mu \mathrm{m}$ long, on each segment of body; longest setae (Fig. 5L), each 60-130 $\mu \mathrm{m}$ long, on thorax and in medial longitudinal lines on abdomen. Hairs (Fig. 5A) sparsely scattered on abdomen. Long caudal setae (Fig. 5J), each about 750-900 $\mu \mathrm{m}$ long, with 2 pairs posteriorly on abdomen, and another 2 long setae laterally on each side of posterior abdomen; a medial pair of shorter hair-like setae, each about $200 \mu \mathrm{m}$ long, between long caudal setae. Cicatrices circular, each $30-40 \mu \mathrm{m}$ in diameter, 3 in number, in a medial transverse line on posterior end of abdomen (Fig. 5K). Disc-like tubercles absent.

\section{Mimosicerya Cockerell}

Palaeococcus (Mimosicerya) Cockerell, 1902a: 233. Type species: Icerya (Crypticerya) hempeli Cockerell, by monotypy. Clypeococcus Newstead, 1920: 175. Type species: Icerya (Crypticerya) hempeli Cockerell. Synonymy by Morrison, $1928: 105$. Mimosicerya Cockerell; Morrison, 1928: 104. Change of status.

Nautococcus Vayssière, 1939: 124. Type species: Nautococcus schraderae Vayssière, by monotypy. syn. n.

Cockerell (1902a) erected Mimosicerya as a section of Palaeococcus, not as a section of Icerya as stated by Morrison (1928) and Ben-Dov (2014). Icerya (Crypticerya) hempeli was described by Cockerell (1899) based on insects collected by A. Hempel on Mimosa(?), on May 12, 1898, at Campinas, São Paulo state, Brazil. One year later, Hempel (1900) published the name as Crypticerya hempeli and soon after Palaeococcus (Mimosicerya) was established by Cockerell (1902a) as a section of the genus Palaeococcus. Cockerell's designation of its rank corresponds to the nomenclatural requirement of a subgenus (Article 10.4 of ICZN) and is in the form of a genusgroup name with a description and a designated type species, i.e. Icerya (Crypticerya) hempeli Cockerell. Later, Newstead (1920) received from Brazil (São Paulo, on spiny branches of tree or shrub (mimosa?), collected in 1906) scale insects that he compared with a specimen of I. (Crypticerya) hempeli from the collection of Cockerell via E.E. Green and, based on these, erected a new genus Clypeococcus for its reception. The genus name was based on the possession of a supposed clypeus but, in reality, this corresponds to a fold in the derm anterior to the attachment of the labium in the preadult female. Shortly after his publication, Newstead (in correspondence to G.F. Ferris, March 16th, 1920, housed in BME) noted that he had overlooked Cockerell's (1902a) paper and regretted that he had "added another useless synonym". Morrison (1928) revised and diagnosed the taxon, changed the status to Mimosicerya, and formally recognised Clypeococcus as its synonym.

Mimosicerya remained a monotypic genus for over 100 years, until Foldi (2009) added a new species from Venezuela, M. williamsi Foldi, with descriptions of the adult and preadult females. Here we add two more species: Nautococcus schraderae Vayssière, which becomes a species of Mimosicerya by synonymy of Nautococcus with Mimosicerya (see under M. schraderae below), and Cryptokermes mexicanus Morrison, which we transfer to Mimosicerya (see under M. mexicana below). We redescribe and illustrate all species except M. williamsi, which was recently treated in detail and compared with M. hempeli by Foldi (2009). 
Generic diagnosis. All stages live either exposed, or hidden in cracks or under bark on twigs or stems of the host plant; the adult female is pupillarial, remaining inside the sclerotised preadult exuviae for reproduction.

Adult female. Body broadly oval, female remaining within preadult exuviae after last moult. Derm membranous except for an approximately circular sclerotised area anteriorly bearing antennae, eyespots, multilocular pores, setae and numerous spines of varying stoutness and length. Ventral dermal pocket-like depressions (apodemes) present, 2 per segment in a submedian line on abdomen ( $M$. hempeli) or absent ( $M$. mexicana, M. schraderae and M. williamsi). Antenna greatly reduced, platelike or bulbous, segments not discernable on slide-mounted specimens, but bearing a group of sensory setae. Mouthparts absent. Legs either absent (M. schraderae and M. mexicana), present but strongly reduced (M. hempeli) or represented by vestigial protuberances ( $M$. williamsi). Thoracic spiracles wide, each with a group of perispiracular multilocular pores. Abdominal spiracles numbering 7 pairs, with posteriormost pair close to anal opening; peritremes each situated on a truncate sclerotized protrusion in M. hempeli but not in M. mexicana, M. schraderae or M. williamsi; each spiracle with or without atrial pores. Anal tube of preadult retained. Multilocular pores circular or broadly oval with a thickened rim; each with a circular or oval, rarely triangular or quadrate, centre and with 10-16 outer loculi, distributed throughout both dorsum and venter, most abundant toward posterior end; raised pores, if present, only on sclerotised head area. Spines present on sclerotised anterior area and sometimes spines or spiniform setae present elsewhere, particularly on posterior end of body. Flagellate and hair-like setae sparsely scattered over body. Hairs, if present, sometimes with a swollen apex (M. hempeli) and most common on posterior end of abdomen. Cicatrices and disc-like tubercles absent.

Third-instar (preadult) female. Body globular to nearly spherical in life. Derm thick and sclerotised dorsally and marginally in mature specimens, often membranous only on mid-ventral area. Dorsal posterior end of abdomen of mature specimens sclerotised and bearing a wide circular area of derm, surrounded by a wide rim in M. hempeli; in $M$. schraderae, this circular area of derm is known to form an operculum that lifts, allowing abdomen of adult female to protrude (Fig. 14). Antenna 7 (M. mexicana) or 9 segmented (M. hempeli, M. schraderae and $M$. williamsi); each segment with a few fleshy setae as well as slender hair-like setae. Eyespot situated lateral to scape. Mouthparts present; labium small. Legs well developed, trochanter with a long ventral seta and with 2 campaniform sensilla on each side; claw stout, without a denticle but with a pair of setose digitules. Thoracic spiracles large, each with perispiracular multilocular pores. Abdominal spiracles small, numbering 7 pairs; all atria with pores. Anal opening apical and anal tube with polygonal wax pores at inner end, also with 2 or 3 rows of multilocular pores nearer to anal opening. Multilocular pores with either a triangular, quadrate or circular centre, distributed throughout on dorsum and margin; mid-ventral area with a few multilocular pores distributed in transverse rows. Flexible cylindrical long hairs, each with an expanded base and mostly with a swollen apex, either densely covering sclerotised margins of mid-ventral area and thorax (M. hempeli), or near mouthparts only ( $M$. schraderae), or densely covering medial to submedial thorax (M. williamsi), or rare (M. mexicana). Short stout setae, slender setae and spinose setae sparsely scattered on dorsum. Spines absent (M. hempeli) or present ( $M$. mexicana, M. schraderae and M. williamsi). Ventral cicatrices, varying in size, numerous, usually scattered on thorax and in transverse segmental rows on abdomen; sometimes also on dorsum. Disc-like tubercles present in all species, with various distributions.

First-instar nymph. Body elongate, elliptical. Antenna 6 segmented, third segment very short in $M$. hempeli and M. schraderae, pedicel and apical segment longest; apical segment swollen and bearing fleshy setae at apex. Clypeolabral shield well developed; labium 3 segmented, apical segment with sensory setae. Legs well developed; claw elongate with a pair of setose digitules. Thoracic spiracles each with 1 or 2 perispiracular pores. Abdominal spiracles numbering 7 pairs, small, without atrial or perispiracular pores. Anal opening apical to subapical; anal tube short, inner end with a double collar of polygonal wax pores. Dorsal and ventral pores small, mostly circular, each with 3-6 inner loculi and a variable number of outer loculi. Spines stout, cylindrical, pointed at apex, distributed on posterior dorsum, densest around anal area in all species. Slender hair-like setae with a stout conical base, sparse across abdominal segments; hairs and flagellate setae sparsely distributed. Long caudal setae in 3 pairs on posterior abdominal segment, plus 3-6 pairs of long setae on margin. Cicatrices flat and circular, 3 in number, in a transverse row ventromedially on posterior abdomen. Disc-like tubercles, each toadstool shaped in side view with a slightly domed centre, numerous in transverse rows on dorsum and either numerous towards posterior end ( $M$. hempeli) or absent at posterior end (M. schraderae). 


\section{Mimosicerya hempeli (Cockerell)}

Icerya (Crypticerya) hempeli Cockerell, 1899: 43.

Crypticerya hempeli; Hempel, 1900: 376. Change of combination.

Palaeococcus hempeli; Cockerell, 1902a: 233. Change of combination.

Clypeococcus hempeli; Newstead, 1920: 175. Change of combination.

Mimosicerya hempeli; Morrison, 1928: 105. Change of combination.

This species was described by Cockerell (1899) based on what he believed to be the adult female. However, he described 9-segmented antennae and small stout legs, which are characteristic of the third-instar (preadult) female. The collection data for the type material was given as "Campinas, Brazil, May 12, 1898, on Mimosa (?). (A. Hempel, 215d)". Later, Newstead (1920) also described and illustrated the preadult female, believing it to be the adult and described and illustrated the first-instar nymph. Later still, Morrison (1928) recognised that the preadult exuviae concealed the pharate adult female and described the adult and preadult females and the first-instar nymph. Males are not known.

Type material examined. BRAZIL: Syntypes: 1 adult female and 2 preadult females, each on a separate slide with label: "Palaeococcus / hempeli (Ck1l) / Co-Type / Campinas / 1900" or "Palaeococcus / hempeli (Ck11) / CoType /Campinas / 1900 / Co-Type" (USNM); one slide with 16 first-instar nymphs, labelled "Paleococcus[sic] / hempeli (Ckll) / on Mimosa ? / Hempel / Type material" (USNM); 3 dry preadult females with remains of adult females inside, each glued to a separate card, in a box in dry collection with labels: "Crypticerya / hempeli / Ckll. / Campinas / Co-type / 3", and a red printed label: "COTYPE / M.A.C.", a slide of 1 of these 3 preadult females prepared by P.J. Gullan, 2009 (USNM); 4 dry and very mature preadult females, loose in 3 boxes in dry collection with labels inside 2 boxes: " 3 Co-type / Crypticerya / hempeli Ckll." and outside of those 2 boxes labelled: "Palaeecens hempeli (Ckll) / Mimosicerya / Campinas (Hempel) CO-TYPE", and third box labelled only outside as: "Palaeococcus hempeli (Ckll) / on Mimosa ? / Mimosicerya / Brazil (Hempel) TYPE Ckll. Coll."; this last box has one dry preadult female.

Note: It is clear that the above four boxes in the USNM contain Cockerell's type material, from which specimens probably later were slide-mounted for Morrison's (1928) monograph. Morrison provided detailed illustrated descriptions of the adult and preadult females and the first-instar nymph that would have required slidemounted specimens. It seems that the labelling of the three USNM slides of type specimens with the collection date of 1900 was just an error on the labels, and we believe that these females are part of the type material. There is one slide of Cockerell's type material in the Natural History Museum in London (Williams, 1985), but it consists of pieces of cuticle only, and although the collection data show that the specimen is from the type material, the slide is not labelled as being a type. We have not designated a lectotype because there is no doubt as to the identity of this species; also the one box that has a label ("TYPE Ckll. Coll.") indicating that it is primary type (rather than "COTYPE") contains a single dry mature preadult female that would be difficult to slide-mount. Thus all original specimens are listed as syntypes.

Clypeococcus hempeli Newstead: BRAZIL: Syntypes: 1 slide with part of 1 preadult female, 1 slide with 3 first-instar nymphs and one box with 1 dry preadult female, all labelled as "Clypeococcus hempeli", São Paulo, Brazil, on spiny branches of unknown tree, 1906, purchased from O. E. Janson (BME). Note: These specimens were sent to G.F. Ferris by Newstead (as noted in Newstead's correspondence to G.F. Ferris, March 16th, 1920) and were part of Newstead's type series. The Natural History Museum, London, has dry specimens of this Newstead species but no slide preparations could be located.

Other material examined. BRAZIL: 1 adult female in excellent condition, and a second in poor condition, plus 2 slides each with 4 first-instar nymphs, São Paulo State, Itarare, on Piptadenia falcata, Aug. 20, 1928, A. Hempel coll. (USNM); 2 preadult females on 2 slides and 2 unmounted preadults from dry material, labelled as cotype of Palaeococcus hempeli Cockerell, sent by von Ihering in 1900 to the Museum, Paris, slides prepared by I. Foldi, 1987 (MNHN); 1 adult female and 2 preadult females, Paraná State, Mata Atlantica, on stems of Mimosa, 9.xi.1985, I. Foldi coll, and prepared 1987 (MNHN).

Adult female (Fig. 6). Unmounted material. Protected inside sclerotised cuticle of preadult female and reproducing therein. For slide preparation, adult females were extracted from preadult exuviae.

Mounted specimens ( $\mathrm{n}=2)$. Body nearly spherical, 7.5-9.0 mm long, 4.7-6.0 mm wide. Anterior end of body with an approximately circular, strongly sclerotised area extending from dorsal head through to ventral prothorax; 
this zone covered with spines of varying stoutness, multilocular pores and setae, and enclosing antennae and eyespots, sometimes also including prothoracic legs and part of mesothoracic spiracles. Rest of derm membranous, but ventral sclerotised pocket-like depressions (apodemes) present in a submedian line on each side of abdomen. Antenna plate-like, segmentation not apparent, bearing numerous setae (Fig. 6A). Eyespot situated lateral to antennal scape. Mouthparts absent. Legs (Fig. 6K) reduced, about 350-380 $\mu \mathrm{m}$ long, with segments indistinct, bearing stout short setae, each 15-35 $\mu \mathrm{m}$ long, distal part of each leg ending in a narrow finger-like segment without a claw; basal part (apparently coxa) widest segment. Thoracic spiracles (Fig. 6M) each with peritreme 320-340 $\mu \mathrm{m}$ wide and about 60 perispiracular multilocular pores; each spiracle with a wide apodeme. Abdominal spiracles (Fig. 6F) numbering 7 pairs, each with peritreme 55-60 $\mu \mathrm{m}$ wide situated on protrusion about $60-70 \mu \mathrm{m}$ high; each spiracle without either atrial or perispiracular pores; posterior pair situated close to anal opening. Vulvar opening transversely elongate, surrounded at each extremity by 2 apodemes ( 4 in total). Anal tube (Fig. $6 \mathrm{H}$ ) membranous, about $460 \mu \mathrm{m}$ long, with anal tube of preadult retained.

Dorsum. Multilocular pores (Fig. 6C), each 10-11 $\mu \mathrm{m}$ in diameter and located at centre of circular sclerotised raised derm; pores + raised derm together 16-25 $\mu \mathrm{m}$ in diameter; each pore with a circular centre and about 14-16 outer loculi; pores scattered among spines (Fig. 6B). Other multilocular pores (Fig. 6E), each 10-11 $\mu \mathrm{m}$ in diameter with a circular centre, about 14-16 outer loculi and a thickened rim, similar to pores in Fig. 6C but without raised derm; distributed sparsely in segmental rows on abdomen, most abundant towards posterior segments. Stout spines (Fig. 6B), each mainly straight and 25-55 $\mu \mathrm{m}$ long, a few with swollen apices, densely covering anterior sclerotised area, sparsely mixed with slender hair-like setae (Fig. 6D), each 20-70 $\mu \mathrm{m}$ long, rarely up to $145 \mu \mathrm{m}$; periphery of sclerotised area with numerous curved spines (Fig. 6B), each 30-40 $\mu \mathrm{m}$ long, some with a swollen apex. Slender and stouter hair-like setae (Fig. 6G), each 30-40 $\mu \mathrm{m}$ long, sparse in transverse rows across of all segments of body. Hairs, each with an expanded base and a swollen apex (Fig. 6I), sparsely present on thorax and posterior end of body. Cicatrices and disc-like tubercles absent.

Venter. Multilocular pores (Fig. 6E), similar to those on dorsum, each about $11 \mu \mathrm{m}$ in diameter with a thickened rim, a circular centre and about 14-16 outer loculi, present in transverse bands on abdomen, particularly dense posteriorly around vulvar area. Spines more slender than in sclerotised area, straight or curved (Fig. 6L), sparse on thorax, mostly present around thoracic spiracles where mixed with long, flexible hairs, each with a swollen apex (Fig. 6I). Short hair-like setae (Fig. 6D), each 30-40 $\mu \mathrm{m}$ long, sparsely scattered over body; stouter hair-like setae (Fig. 6G) most abundant toward posterior end of abdomen. Flagellate setae, each 60-80 $\mu \mathrm{m}$ long, and shorter, hair-like setae (Fig. 6G) densely present in vulvar area. Posterior end with a group of 25-30 unusually complex, wide pores, about 20-25 $\mu \mathrm{m}$ deep (Fig. 6J). Cicatrices and disc-like tubercles absent.

Third-instar (preadult) female (Figs 1B, 7). Unmounted material. Living exposed on bark; body subglobose, dark slate-gray with a thin but dense coating of cream-coloured mealy secretion; subdorsal areas marked by a longitudinal series of small round spots free from secretion; legs blackish brown to dark brown (Cockerell, 1899). Young preadults reddish-brown but becoming darker with age, with derm strongly sclerotised in old specimens.

Mounted specimens ( $\mathrm{n}=5)$. Body nearly circular, 7.5-10.0 mm long, 5.2-8.0 mm wide. Derm of dorsum and margin sclerotised, mid-ventral region membranous and with small spinules densely distributed on thorax and abdomen. Antenna 9 segmented, 590-610 $\mu \mathrm{m}$ long, each segment mainly with hair-like setae each 40-50 $\mu \mathrm{m}$ long, slender setae each 40-90 $\mu \mathrm{m}$ long, but more distal segments (except apical) also with 2 stout fleshy setae; apical segment (Fig. 7A), 108-112 $\mu \mathrm{m}$ long, $80 \mu \mathrm{m}$ wide, bearing 5 or 6 thick fleshy setae, each 40-50 $\mu \mathrm{m}$ long, hair-like setae and about 4 slender setae, each 60-70 $\mu \mathrm{m}$ long. Eyespot situated posterolateral to antennal scape. Clypeolabral shield about $450 \mu \mathrm{m}$ long; labium apparently 3 segmented, about $350 \mu \mathrm{m}$ long, apex with about 12 setae. Legs (Fig. 7M) well developed, segments stout and short; metathoracic leg: coxa about $200 \mu \mathrm{m}$ long, $260 \mu \mathrm{m}$ wide, with few setae; trochanter + femur about $570 \mu \mathrm{m}$ long; trochanter with a long ventral seta, about $210 \mu \mathrm{m}$ long, with 2 campaniform sensilla on each side and a few setae about $55 \mu \mathrm{m}$ long; with similar setae on femur; tibia about $470 \mu \mathrm{m}$ long with ventral setae 50-70 $\mu \mathrm{m}$ long, tarsus about $200 \mu \mathrm{m}$ long with setae $25-35 \mu \mathrm{m}$ long; claw stout, curved, about $70 \mu \mathrm{m}$ long with a pair of setose digitules. Thoracic spiracles (Fig. 7P) each with peritreme 160-170 $\mu \mathrm{m}$ wide and about 16-19 perispiracular multilocular pores. Abdominal spiracles (Fig. 7E) numbering 7 pairs, enclosed in thick sclerotised derm, most posterior pair smallest; each atrium 25-30 $\mu \mathrm{m}$ wide when viewed from above; peritremes becoming progressively smaller posteriorly, from $80 \mu \mathrm{m}$ to $30 \mu \mathrm{m}$ wide, and each spiracle with 6-9 multilocular atrial pores mainly with a triangular or quadrate centre. Anal tube (Fig. 7F), $550 \mu \mathrm{m}$ long, 
with polygonal wax pores at inner end, and about 2 or 3 rows of multilocular pores nearer to anal opening. Dorsal posterior with slightly sclerotised area of derm $680-730 \mu \mathrm{m}$ in diameter, with a central wide circular area surrounded by a strong rim bearing a few raised pores (Fig. $7 \mathrm{H})$.

Dorsum. Multilocular pores (Figs 7B, D), each 10-11 $\mu \mathrm{m}$ in diameter, numerous on sclerotised dorsum and margin; most commonly with 5 or 6 (rarely up to 7 or 8) central loculi, and about 10-12 tiny outer loculi. Raised multilocular circular pores (Fig. 7H), each 10-11 $\mu \mathrm{m}$ in diameter with 5 or 6 (mostly 5) circular loculi, numerous in anal area. Setae few, mostly stout hair-like setae (Fig. 7C), each 80-90 $\mu \mathrm{m}$ long, sparsely scattered over surface. Disc-like tubercles with a domed centre (Fig. 7G), each about 9-12 $\mu \mathrm{m}$ in diameter born on a narrower base, 5-7 $\mu \mathrm{m}$ wide, $6-8 \mu \mathrm{m}$ high, and located in a dermal depression; numerous and scattered. Also larger disc-like tubercles (Fig. 7J), each 20-25 $\mu \mathrm{m}$ in diameter with a central opening, sparsely mixed with smaller disc-like tubercles.

Venter. Medial to submedial area of abdomen membranous and clear, delimited by a dense band of hairs (Fig. $7 \mathrm{~N}$ ) and sclerotised submarginal derm. This clear area with cicatrices (Fig. 7I) of various sizes, each 15-30 $\mu \mathrm{m}$ wide in an irregular transverse row 1-2 cicatrices wide on each abdominal segment, even extending a short distance onto sclerotised venter; also with a few multilocular pores, each about $10 \mu \mathrm{m}$ wide and mainly with 3 or 4 (rarely 6) loculi at centre and 10-12 outer loculi (Figs 7K, L). Small, circular pores (Figs 7R, S), each 6-7 $\mu \mathrm{m}$ in diameter with 3 or 4 loculi, sparsely scattered on venter. Long, flexible, cylindrical hairs (Fig. $7 \mathrm{~N}$ ) each mainly $70-110 \mu \mathrm{m}$ long but with a few only 40-50 $\mu \mathrm{m}$ long, and with an expanded base and a swollen apex, densely distributed on weakly sclerotised ventral margins of abdomen, also sparse on membranous ventral area and on head and thorax, where mixed with sparsely scattered short flagellate setae (Fig. 7O), each 20-30 $\mu \mathrm{m}$ long. Sclerotised margins and submargins with disc-like tubercles with a central opening (Fig. 7J) plus a few smaller, domed disclike tubercles.

First-instar nymph (Fig. 8). Mounted specimens ( $\mathrm{n}=16)$. Body elongate elliptical, 840-950 $\mu \mathrm{m}$ long, 530-550 $\mu \mathrm{m}$ wide; derm membranous. Antenna 6 segmented, 430-450 $\mu \mathrm{m}$ long, third and fifth segments short; apical segment (Fig. 8B) 93-100 $\mu \mathrm{m}$ long and swollen, 55-60 $\mu \mathrm{m}$ wide, bearing 4 thick fleshy setae, each $30 \mu \mathrm{m}$ long, and 6 or 7 slender setae, each $70-100 \mu \mathrm{m}$ long. Eyespot situated posterolateral to antennal scape. Labium 3 segmented; apical segment with about 6-8 acute sensory setae, $35 \mu \mathrm{m}$ long, at apex. Legs slender (Fig. 8L), each about $400 \mu \mathrm{m}$ long, each segment with setae 40-45 $\mu \mathrm{m}$ long; trochanter with 2 campaniform sensilla on each side; tarsus about $150 \mu \mathrm{m}$ long with about 8 setae $30 \mu \mathrm{m}$ long, proximal part of tarsus with 1 campaniform sensillum (Fig. 8L: cs); claw curved, elongate, about $45 \mu \mathrm{m}$ long with a denticle and a pair of setose digitules (Fig. 8K). Thoracic spiracles (Fig. 8P) each with atrium about 23-25 $\mu \mathrm{m}$ wide, peritreme about $30 \mu \mathrm{m}$ wide with a single perispiracular multilocular pore. Abdominal spiracles (Fig. 8I) numbering 7 pairs, small; each atrium about 16-18 $\mu \mathrm{m}$ long, 8-9 $\mu \mathrm{m}$ wide, without atrial and perispiracular pores. Anal opening dorsal; anal tube (Fig. 8G) membranous, short, about $40 \mu \mathrm{m}$ wide, inner end with a double collar of polygonal wax pores.

Dorsum. Rectangular pores (Fig. 8E), each $8-9 \mu \mathrm{m}$ wide with a quadrate centre and 4 wide outer loculi, sparsely distributed. Quinquelocular circular pores (Fig. 8D), each with 5 central loculi and 5 outer loculi, in longitudinal lines on body. Spines (Fig. 8F) stout, cylindrical, pointed at apex, 18-25 $\mu \mathrm{m}$ long, sparsely scattered on abdomen in transverse rows; spines curved (Fig. 8F), in dense clusters on each side of anal opening; a few stout, short spines, each 10-11 $\mu \mathrm{m}$ long and parallel-sided with a rounded apex, present on abdomen. Slender hair-like setae (Fig. 8C), each 25-30 $\mu \mathrm{m}$ long, sparse across abdominal segments, mixed with shorter hair-like setae, each 18-20 $\mu \mathrm{m}$. Circular disc-like tubercles (Fig. 8A), each 8-11 $\mu \mathrm{m}$ in diameter, appearing to have an open centre when viewed from above, scattered on head and thorax, most numerous in transverse rows on abdomen.

Venter. Multilocular pores (Figs $8 \mathrm{H}, \mathrm{N}$ ), each $7-8 \mu \mathrm{m}$ in diameter with a triangular centre and with 3 paired (Fig. 8H) or 3 single (Fig. 8N) tiny outer loculi, but pores with 3 paired outer loculi sparse; present in longitudinal lines on abdominal segments. Hair-like setae, each 15-20 $\mu \mathrm{m}$ long, scattered on head and thorax, and in transverse rows 1 seta wide, across all abdominal segments; longest hair-like setae (Fig. 8O), each $50 \mu \mathrm{m}$ long, on head, thorax and in medial area of each abdominal segment. Hairs (Fig. 8M) scattered on abdomen. Caudal setae in 3 pairs on posterior abdominal segment, each seta 360-430 $\mu \mathrm{m}$ long (Fig. 8R), plus 3 pairs of lateral setae on margin of abdomen, $360 \mu \mathrm{m}$ to $140 \mu \mathrm{m}$ long, becoming progressively shorter anteriorly. Cicatrices circular, 3 in a transverse line medially on posterior abdomen, middle one small, about $11 \mu \mathrm{m}$ in diameter, lateral ones each $21-23$ $\mu \mathrm{m}$ in diameter. Disc-like tubercles absent. 


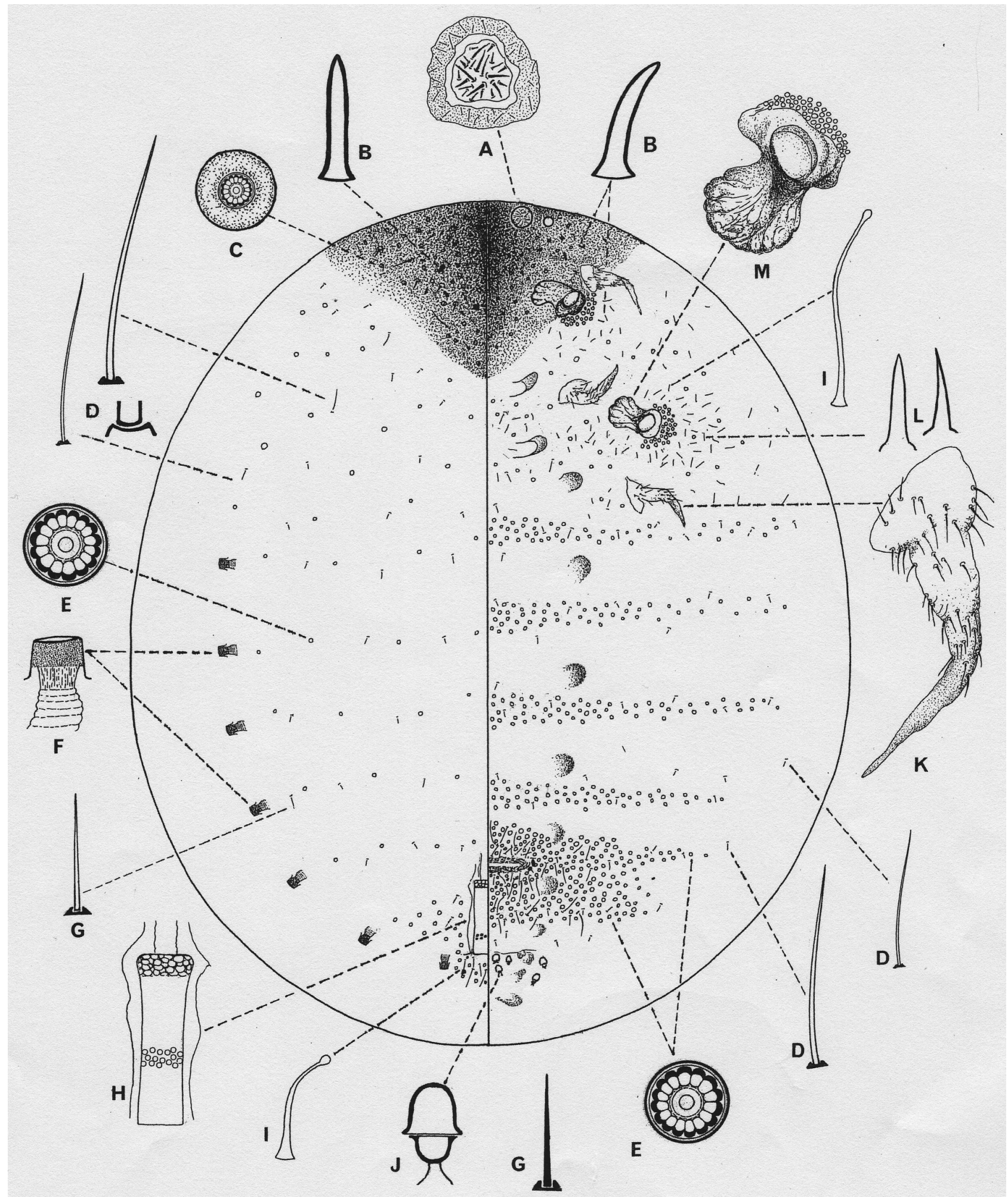

FIGURE 6. Mimosicerya hempeli (Cockerell). Adult female. A. plate-like antenna with sensory setae; B. dorsal and ventral stout, straight and curved spines within sclerotised area; C. multilocular pore at centre of raised, circular, sclerotised derm; D. slender hair-like setae; E. common multilocular pore with circular centre and 15 outer loculi; F. abdominal spiracle with protruding peritreme; G. short hair-like seta; H. tube anal with polygonal wax glands at inner end; I. short or long flexible hair with swollen apex; J. ventral tubular structure near posterior end; K. metathoracic leg without discernable segments; L. straight and curved spines around spiracles; M. thoracic spiracle with perispiracular multilocular pores. 


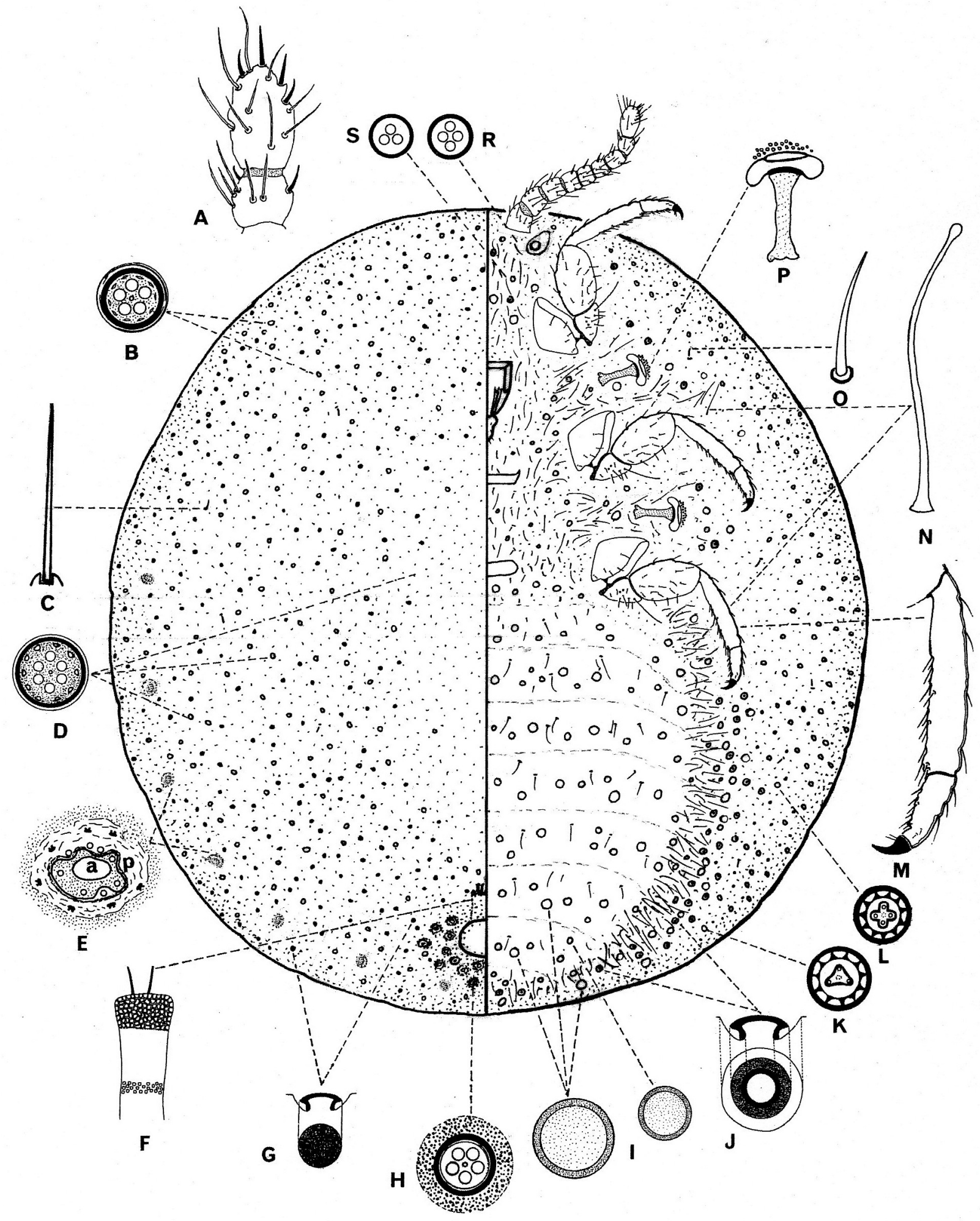

FIGURE 7. Mimosicerya hempeli (Cockerell). Third-instar female (preadult). A. apical segments of antenna; B. multilocular pore with quinquelocular centre; C. short hair-like seta; D. multilocular pore with 6-locular centre; E. view from above of abdominal spiracle located within thick derm, $a=$ atrium, $p=$ peritreme; F. anal tube; G. disc-like tubercle; H. quinquelocular pore at center of raised sclerotised derm; I. cicatrices of variable sizes; J. disc-like tubercle; K. multilocular pore with triangular centre; L. multilocular pore with quadrate centre; M. tibia, tarsus and claw of metathoracic leg; N. long, flexible, cylindrical hair with swollen apex; O. flagellate seta; P. thoracic spiracle with perispiracular multilocular pores; R. simple quadrilocular pore; S. simple trilocular pore. 


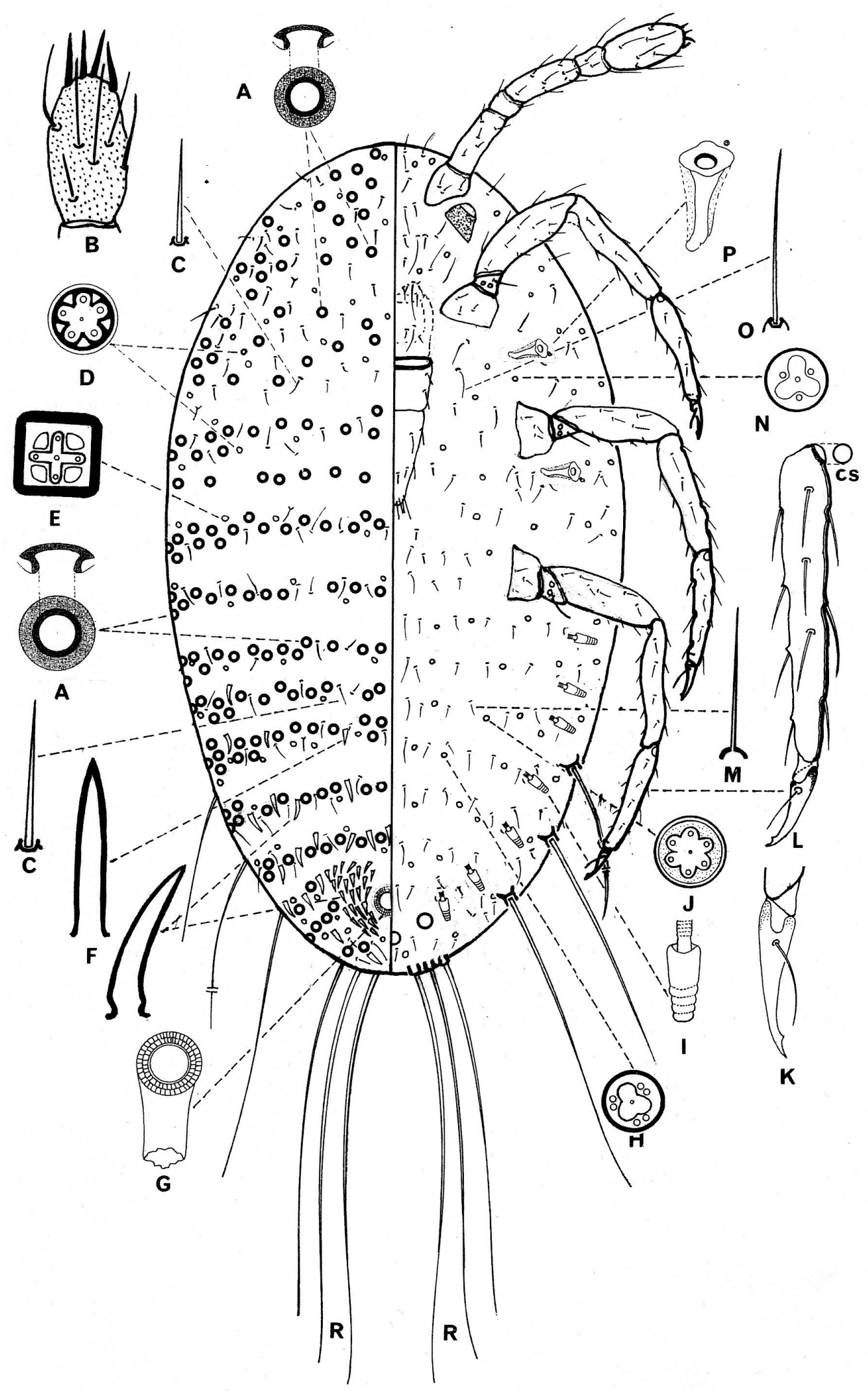

FIGURE 8. Mimosicerya hempeli (Cockerell). First-instar nymph. A. disc-like tubercle; B. apical segment of antenna; C. short hair-like setae; D. quinquelocular pore; E. pore with rectangular quadrilocular centre and 4 outer loculi; F. straight or curved spines; G. tube anal with polygonal wax pores at inner end; H. pore with large triangular centre and 3 tiny paired outer loculi; I. abdominal spiracle; J. pore with 6 loculi; K. claw with a denticle and digitules; L. metathoracic tarsus and claw, proximal part of tarsus with a campaniform sensillum (cs); M. flagellate seta; N. pore with triangular centre and 3 tiny outer loculi; O. ventromedial long hair-like seta; P. thoracic spiracle with one perispiracular multilocular pore; R. 3 pairs of long caudal setae. 


\section{Mimosicerya mexicana (Morrison) comb. $\mathbf{n}$.}

Cryptokermes brasiliensis; Cockerell, 1902b: 469. Misidentification; discovered by Morrison, 1927: 103.

Cryptokermes brasiliensis; Ferris, 1918: 22. Misidentification; discovered by Morrison, 1927: 103.

Cryptokermes mexicanus Morrison, 1927: 103.

There have been several descriptions of this species. Cockerell (1902b) and Ferris (1918) both erroneously referred to the species as Cryptokermes brasiliensis. Later, Morrison (1927) named the species as Cryptokermes mexicanus and provided the details of the type specimens (see below). Morrison (1928) pointed out that Ferris' (1918) and Cockerell's (1902) descriptions were actually of C. mexicanus. There is no mention of a test in any of the above four papers, and Ferris (1918, page 221) says of the adult female: "remaining enclosed within the derm of the penultimate stage", which is a characteristic of the genus Mimosicerya. Also Morrison (1927, page 103) describes the first-instar nymph as having curious derm discs that are flattened or with the centre slightly convex. We examined these structures under the compound microscope and they are toadstool shaped in side view and exactly match the disc-like tubercles of the first-instar nymph of $M$. hempeli, rather than the disc-like tubercles of the firstinstar nymph of $C$. brasiliensis. Based on the morphological features of the first-instar nymph and the preadult and adult females, we have confirmed that $C$. mexicanus belongs to Mimosicerya and here transfer it to that genus as $M$. mexicana. As the genus name Mimosicerya (based on Icerya Signoret) is feminine and the species name is an adjective (Pellizzari \& Williams, 2013), the latter should be amended to "mexicana". We describe the adult female, preadult female and first-instar nymph, but illustrate only the latter because that instar is the best for species recognition.

Morrison (1927, page 103) listed two type collections, as follows: "Zapotlan, Jalisco, Mexico, on Mimosa sp., 1903, collected by C.H.T. Townsend (T. \& B. Cy. \#22) (holotype and paratypes); and from Cuautla, Morelos, Mexico, on Mimosa sp., July, 1897, collected by A. Koebele (\#1609 - Div. Ent. \#7894 - and \#1672 - Div. Ent. \#7918) (paratypes)". The types are in the USNM, as stated by Morrison (1927), but the BME also holds slidemounted specimens with the above data and these were apparently mounted by G.F. Ferris; the BME also has one collection of dry material from the Zapotlan locality. Cockerell sent some of the Zapotlan specimens to Ferris, as stated by Ferris (1918), but it is not known how the Cuautla specimens were obtained by Ferris. However, given the collection data, both BME collections must have come from the original collections made by Townsend and Koebele, but were not the specimens seen by Morrison (1927) when he described C. mexicanus, and thus they are not part of the type series. Each of Ferris' slides of specimens from Zapotlan is labelled as "heautotype; this name was applied to a specimen used by the original describer as an illustration of the species and compared with the type or cotype. The USNM has 15 slides from the Zapotlan series from Townsend and 23 slides from the Cuautla series from Koebele. The slide in the USNM marked as "holotype" has label data: "Cryptokermes / brasiliensis Hemp / mexicanus / On Mimosa sp. (wild) / Zapotlan, Jalisco, /Mexico / T. \& B. Cy. \#22 / Rec'd. July 1903" with the word "holotype" scratched on the glass of the slide. We have not examined Morrison's type specimens in the USNM.

Material examined from type localities. MEXICO: 1 adult female, remains of 1 adult female, 2 preadult females, 1 second-instar nymph, 1 first-instar nymph and separate slide with 1 first-instar nymph + a second-instar exuviae, 7 slides in total, each with handwritten label "Cryptokermes brasiliensis Hem. / On Mimosa sp. / Zapotlan, Mex. / Townsend col. / Ckll det. Heautotype / G.F.F." and printed text: "Entomological Laboratory / Stanford University" (BME); 4 first-instar nymphs on each of 2 slides, ex dry stem bark in box with handwritten label: "Cryptokermes /brasiliensis / Hempel. on / Mimosa sp. Zapotlan. / Mexico (Townsend) / notice the larvae / with tails", slides prepared by P.J. Gullan, 2010 (BME); 2 preadult females on 2 slides and 1 second-instar nymph on a third slide, each slide with handwritten label: "Cryptokermes mexicanus Mor. / on Mimosa / Cuautla, Morelos / Mex." and printed text: "Koebele Collection / Coccidae, No. 1672" (BME).

Other material examined. MEXICO: 4 preadult females on 4 slides, each female ex test stored dry in box with label: "Cryptokermes / mexicanus Morrison / On mimosaceous shrub /called "tepehuaje" / Aguililla, Michoacan. / Jan. 20 1926", slides prepared by P.J. Gullan, 2010 (BME); GUATEMALA: 1 preadult female on 1 slide, on stem of Acacia sp., East of Tulumajillo, on road from El Rancho to Salama, between mile markers 97 \& 101, 30.vii. 2005. M.L. Williams coll., slides prepared by P.J. Gullan, 2006 (BME).

Adult female. Mounted specimen ( $\mathrm{n}=1)$. Body broadly oval, $5.2 \mathrm{~mm}$ long, $5.0 \mathrm{~mm}$ wide. Derm membranous throughout except for a wide circular sclerotised area on anterior end of body and a smaller slightly sclerotised area 
surrounding anal opening on posterior end of body. Antennae not seen. Eyespots appear as 2 light spots within sclerotised area. Mouthparts absent. Legs absent. Thoracic spiracles located on border of sclerotised area; each peritreme about $80 \mu \mathrm{m}$ wide with a group of perispiracular pores and a large apodeme about $285 \mu \mathrm{m}$ long. Abdominal spiracles numbering 7 pairs; each spiracle with a peritreme $35-45 \mu \mathrm{m}$ wide, an internal sclerotised atrium and an external membranous atrium with 4-8 atrial pores; posteriormost pair of spiracles much reduced in size, about $30 \mu \mathrm{m}$ long and, $22 \mu \mathrm{m}$ wide, without atrial pores. Anal tube retained from preadult. Multilocular pores scattered, each $10 \mu \mathrm{m}$ wide with a wide rim; most widespread type with a wide single circular loculus at centre and about 16 loculi in outer rim; these pores more numerous toward posterior end of body; some multilocular pores apparently with an oval centre containing 2 small loculi, sparsely distributed. Short spines sparsely scattered throughout; stouter and longer spines, each 50-55 $\mu \mathrm{m}$ long, densely distributed within sclerotised area on anterior end of body. Hair-like setae and flagellate setae both short and slender, each 25-35 $\mu \mathrm{m}$ long, sparsely scattered throughout. Longest flagellate setae, each 120-130 $\mu \mathrm{m}$ long with a wide, enlarged and sclerotised collar, densely distributed around vulva. Cicatrices and disc-like tubercles absent.

Third-instar (preadult) female. Mounted specimens $(\mathrm{n}=4)$. Body broadly oval, 4.7-6.1 mm long, 4.5-5.6 $\mathrm{mm}$ wide. Derm membranous throughout except posterior end of body, with a wide sclerotised circular area surrounding anal opening. Antenna 7 segmented, in a few cases sixth and seventh segments not always completely separated; total length about 260-310 $\mu \mathrm{m}$ long; apical segment 65-80 $\mu \mathrm{m}$ long with a few hair-like setae, and about 4 fleshy setae. Clypeolabral shield 290-310 $\mu \mathrm{m}$ long; labium about $500 \mu \mathrm{m}$ long, conical, 3 segmented; apical segment with about 6 sensory setae. Legs short and stout, with thick-set segments, each about 480-490 $\mu \mathrm{m}$ long; trochanter with 2 campaniform sensilla on each side and with a long trochanteral seta; claw strongly curved. Thoracic spiracles each with peritreme 60-65 $\mu \mathrm{m}$ wide with numerous perispiracular multilocular pores and a strong apodeme. Abdominal spiracles numbering 7 pairs; each spiracle with atrium 35-40 $\mu \mathrm{m}$ long and with peritreme $28-35 \mu \mathrm{m}$ wide; each atrium with more than 20 multilocular pores; posteriormost spiracle smaller and within sclerotised area. Anal tube, 380-400 $\mu \mathrm{m}$ long, with sclerotised patches on mid-length and near anal opening. Anal opening surrounded by a wide, circular sclerotised area, approximately $1.2-1.4 \mathrm{~mm}$ wide, bearing (i) densely distributed multilocular pores, mostly with a triangular or quadrilocular (rarely quinquelocular) centre and 10-16 small outer loculi, pores located within a sunken centre in a raised sclerotised derm; (ii) spines with pointed apex, each about $25 \mu \mathrm{m}$ long and $15 \mu \mathrm{m}$ wide, densely distributed surrounding raised pores; and (iii) flagellate setae, each 60-70 $\mu \mathrm{m}$ long, surrounding anal opening and located among pores.

Dorsum. Multilocular pores, each about $10 \mu \mathrm{m}$ wide with either a circular or a triangular centre and 12-16 outer loculi, distributed in an irregular transverse row or band on each body segment. Smaller quadrilocular pores sparsely scattered. Stout, enlarged conical spines each 20-25 $\mu \mathrm{m}$ long, scattered on abdomen, most abundant posteriorly. Hair-like setae with conical basal collars, of various sizes: short and thin or thick, each 15-25 $\mu \mathrm{m}$ long, some setae with enlarged apex; longest and thickest setae 45-55 $\mu \mathrm{m}$ long, scattered on all segments. Cicatrices numerous, each $12-30 \mu \mathrm{m}$ in diameter, in a transverse row on each body segment, 1 row sometimes 2 cicatrices wide. Disc-like tubercles, each 7-8 $\mu \mathrm{m}$ in diameter, with a thick rim and domed slightly in centre, densely distributed on body, scattered on head and thorax, and present in transverse segmental rows, 3-5 tubercles wide, on abdomen.

Venter. Multilocular pores each about $10 \mu \mathrm{m}$ wide, with circular, oval or triangular centre, scattered. Stout conical spines as on dorsum, scattered across abdomen, most abundant on posterior end. Hair-like setae, as on dorsum, each 45-55 $\mu \mathrm{m}$ long, most numerous on medial and submedial area. Hairs with expanded bases rare; short flagellate setae present throughout. Cicatrices, each 12-30 $\mu \mathrm{m}$ in diameter, present in a band 1 or 2 cicatrices wide across each abdominal segment. Disc-like tubercles, each about $8 \mu \mathrm{m}$ in diameter and domed in centre, present throughout, densest across abdominal segments.

First-instar nymph (Fig. 9). Mounted specimens (n= 4). Body 950-1200 $\mu \mathrm{m}$ long, 570-690 wide $\mu \mathrm{m}$; derm membranous. Antenna 6 segmented, about $400 \mu \mathrm{m}$ long, segments narrow, each about $40 \mu \mathrm{m}$ wide; a campaniform sensillum present on membranous apex of pedicel; apical segment (Fig. 9A) about $120 \mu \mathrm{m}$ long and $40 \mu \mathrm{m}$ wide, with long setae and 4 or 5 fleshy setae. Eyespot situated lateral to antennal scape. Clypeolabral shield $280-310 \mu \mathrm{m}$ long; labium 3 segmented, about $200 \mu \mathrm{m}$ long. Legs well developed; metathoracic leg: trochanter + femur about $200 \mu \mathrm{m}$ long; trochanter with 2 campaniform sensilla on each side and with a long trochanteral seta, about $120 \mu \mathrm{m}$ long; tibia + tarsus about $325 \mu \mathrm{m}$ long, proximal part of tarsus with a campaniform sensillum; claw (Fig. 9I) narrow, about $35 \mu \mathrm{m}$ long with a denticle near apex. Thoracic spiracles (Fig. 9K) each with peritreme 30-33 $\mu \mathrm{m}$ 


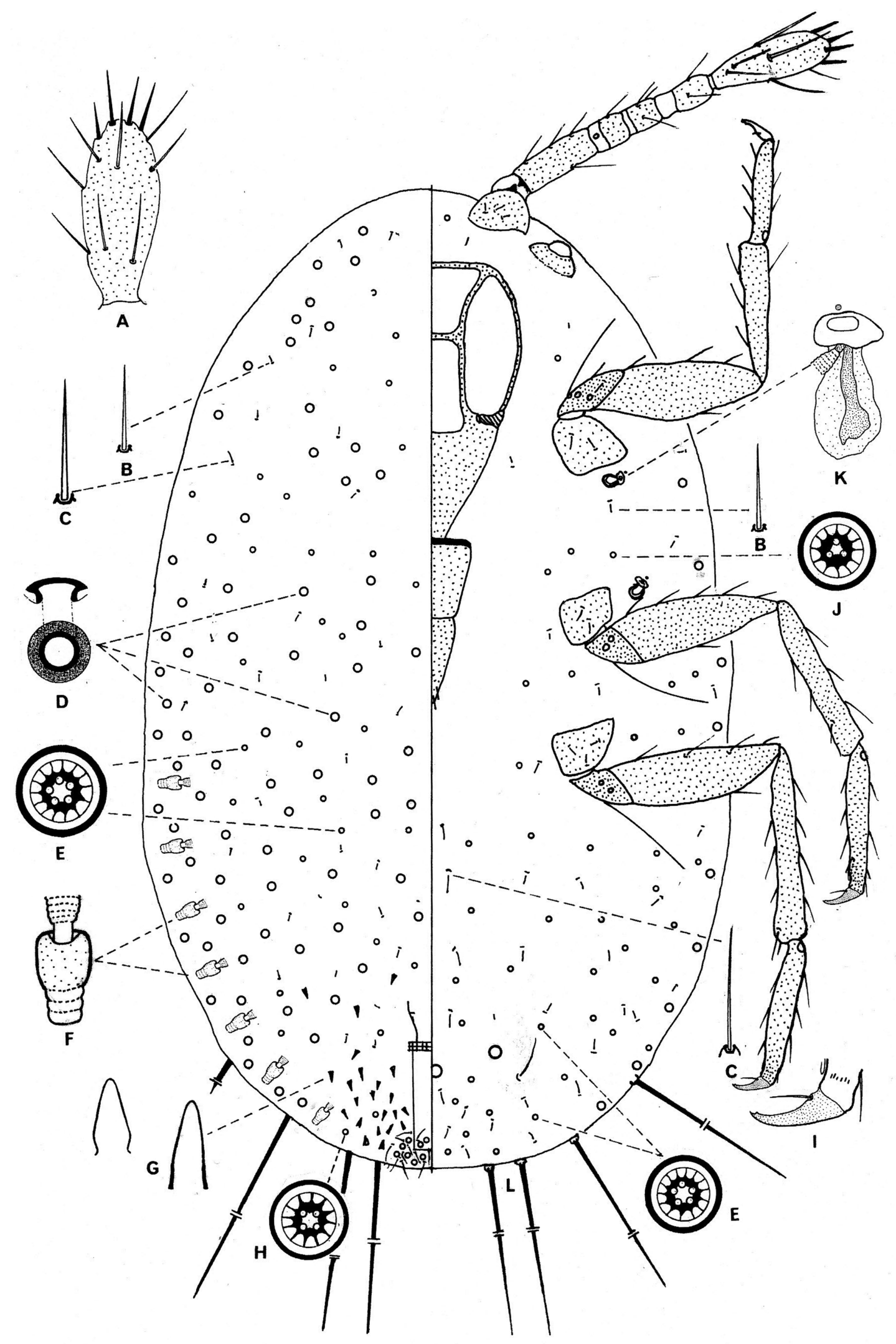

FIGURE 9. Mimosicerya mexicana (Morrison). First-instar nymph. A. apical segment of antenna; B, C. hair-like setae; D. disc-like tubercle; E. multilocular pore with quinquelocular centre; F. abdominal spiracle; G. spines; H. multilocular pore around anal opening; I. metathoracic claw; J. multilocular pore with triangular centre; K. thoracic spiracle with a perispiracular multilocular pore; L. caudal setae. 
wide, each with one perispiracular pore. Abdominal spiracles (Fig. 9F) numbering 7 pairs, each 19-21 $\mu \mathrm{m}$ long and with peritreme 7-8 $\mu \mathrm{m}$ wide; atrial and perispiracular pores absent. Anal tube 120-130 $\mu \mathrm{m}$ long and about $30 \mu \mathrm{m}$ wide, inner end with polygonal wax pores; anal opening surrounded by a circle of multilocular pores mostly with a quadrate centre (Fig. 9H) and by a cluster of setae, each seta 30-50 $\mu \mathrm{m}$ long.

Dorsum. Multilocular pores (Figs 9E, H, J) each about $10 \mu \mathrm{m}$ wide, mostly with a quinquelocular centre (rarely with a triangular or quadrate centre) and about 14 outer loculi, sparsely distributed on thorax, densest on posterior abdomen around anal opening. Stout, straight spines (Fig. 9G), each 16-18 $\mu \mathrm{m}$ long, sparsely scattered on abdomen, denser on posterior abdominal segments. Short hair-like setae (Fig. 9B, C), each 15-26 $\mu \mathrm{m}$ long, sparsely scattered on head and thorax, and in transverse rows on abdominal segments, longest setae 30-50 $\mu \mathrm{m}$ long around anal opening. Cicatrices absent. Disc-like tubercles (Fig. 9D), each 9-10 $\mu \mathrm{m}$ wide with a slightly domed centre in side view, present across each body segment, densest on margin and submargin.

Venter. Multilocular pores (Fig. 9E), each about $10 \mu \mathrm{m}$ wide, similar to those on dorsum, mostly with a quinquelocular centre and about 14 outer loculi, densest on posterior abdominal segments; multilocular pores (Fig. 9J) with a triangular centre and about 12 outer loculi, sparse on thorax. Hair-like setae short, each 12-30 $\mu \mathrm{m}$ long, sparsely scattered on head and thorax, and with about 8-10 setae in a transverse row across each abdominal segment. One long seta of 75-80 $\mu \mathrm{m}$, present near lateral-most cicatrix on each side of body. Caudal setae (Fig. 9L) in 3 pairs, each seta about 450-500 $\mu \mathrm{m}$ long, on posterior end of abdomen, and another long seta laterally on each side of either sixth or seventh abdominal segment. Cicatrices circular, 3 in number, each $8-10 \mu \mathrm{m}$ in diameter, situated medially on posterior abdomen. Disc-like tubercles present on margin only.

\section{Mimosicerya schraderae (Vayssière) comb. n.}

Nautococcus schraderae Vayssière, 1939: 124; Vayssière \& Hughes-Schrader, 1948: 57.

The original description by Vayssière (1939) was based on the preadult female that he had assumed was the adult female. Later Vayssière \& Hughes-Schrader (1948) described the adult female and all other instars, and provided a plate of photographs and information on biology. The species was described from specimens collected in February 1937 by S. Hughes-Schrader on Barro Colorado Island in Panama, Central America, mostly from Annona spraguei (Annonaceae).

There are 56 slides (museum numbers: 6604/1-56) in the MHMN and each is labelled as type of $N$. schraderi [sic]; most are in very poor condition and cuticular structures are difficult to see in many cases. Here we redescribe and illustrate all available instars. We synonymise the genus Nautococcus with Mimosicerya based on morphology of male and female instars, and consequently $N$. schraderae becomes M. schraderae (Vayssière). This species is distinct morphologically from all others in Mimosicerya.

Type material examined. Lectotype of Nautococcus schraderae (here designated): adult female (13 mm long, 10 mm wide), PANAMA: slide labelled: "Nautococcus Schraderi Vays. type, s / Anona spraguei, Barro Colorado Island, Panama, 1937-41, Hughes-Schrader rec. (MHMN). Paralectotypes: all with similar data to lectotype but different slide numbers: 2 adult females on 2 slides, 23 preadult females on 28 slides (in very poor condition); 26 slides, each with many first-instar nymphs; 4 adult males on 4 slides, MHMN numbers: 6604/51, 52, $53 \& 54$ (MNHN).

Adult female (Fig. 10). Unmounted material. Adult female enclosed within thick, strongly sclerotised derm of preadult (Fig. 1C), where it oviposits. Individuals or aggregations of the scale insects are frequently covered by a protective shelter constructed by ants.

Mounted specimens $(\mathrm{n}=4)$. Body broadly ovoid, $10.0-13.0 \mathrm{~mm}$ long, $7.0-10.0 \mathrm{~mm}$ wide; derm membranous except for strongly sclerotised area on head, prothorax and part of mesothorax. Sclerotised zone bearing antennae, eyespots, anterior spiracles and dense spines, but very few setae and multilocular pores. Antenna (Fig. 10C) greatly reduced, plate-like, 165-190 $\mu \mathrm{m}$ in diameter. Eyespot (Fig. 10B) situated near antenna, $190 \mu \mathrm{m}$ wide, lens 80-90 $\mu \mathrm{m}$ wide. Mouthparts absent. Legs absent. Mesothoracic spiracles widest, each peritreme 500-520 $\mu \mathrm{m}$ wide, with more than 100 perispiracular multilocular pores; metathoracic spiracles smaller, each with atrium about $120 \mu \mathrm{m}$ wide, without pores, peritreme 300-370 $\mu \mathrm{m}$ wide with a large group of perispiracular multilocular pores (Fig. 10T). Abdominal spiracles (Fig. 10M) numbering 7 pairs, each spiracle with inner and outer atrium, total length 
about $85 \mu \mathrm{m}, 60-75 \mu \mathrm{m}$ wide at base; inner atrium sclerotised, outer part membranous with 6-14 multilocular pores. Anal tube of preadult retained (Fig. 10I).

Dorsum. Multilocular pores, each 10-11 $\mu \mathrm{m}$ wide with a circular centre and 10 or 11 outer loculi (Fig. 10E), scattered on dorsum. Smaller multilocular pores (Fig. 10H), each 8.5-9.0 $\mu \mathrm{m}$ in diameter with a wide circular centre and 8 outer loculi, scattered, most numerous on posterior segments of abdomen. Slender flagellate setae (Fig. 10F) scattered on dorsum. Hair-like setae (Fig. 10J), each 50-65 $\mu \mathrm{m}$ long, sparse on dorsum, most numerous toward posterior abdominal segments. Sclerotised area on head and part of thorax densely covered with straight (rarely curved) spines with a pointed apex (Fig. 10D), mainly 45-60 $\mu \mathrm{m}$ long; shorter, rounded spines, each 20-40 $\mu \mathrm{m}$ long (Fig. 10A), scattered. Posterior end of abdomen with a large zone densely covered by long hairs (Fig. 10G), each 220-330 $\mu \mathrm{m}$ long, mixed with shorter hair-like setae (Fig. 10J) 55-120 $\mu \mathrm{m}$ long, and multilocular pores (Fig. 8H). Cicatrices and disc-like tubercles absent.

Venter. Multilocular pores (Figs 10N, S), each 10-11 $\mu \mathrm{m}$ in diameter with a bilocular or quadrilocular centre and 12-15 outer loculi, distributed across medial to submedial areas of each abdominal segment, and most numerous around spiracles where mixed with densely distributed short flagellate setae (Fig. 10P). Larger multilocular pores (Fig. 10K), each 11-12 $\mu \mathrm{m}$ wide with a circular centre containing 2 or 4 loculi, and with 20 outer loculi, sparsely scattered among smaller pores and setae in vulvar area. Spines, each stout with a pointed apex (Fig. 10L), similar to those of dorsum, dense in scerotised area on head, prothorax and on posterior end of abdomen. Short flagellate setae (Fig. 10R), each 20-30 $\mu \mathrm{m}$ long, dense around spiracles where mixed with multilocular pores, also present in a band extending to midventral area; longest hair-like setae (Fig. 10O), each 45-65 $\mu \mathrm{m}$ long, sparsely scattered throughout venter. Cicatrices and disc-like tubercles absent.

Third-instar (preadult) female (Figs 1C, 11). Unmounted material. Body broadly ovoid, $9.0-11.0 \mathrm{~mm}$ long, 7-9 $\mathrm{mm}$ wide and 5-6 $\mathrm{mm}$ high; reddish-brown with dorsal and marginal derm strongly sclerotised, mid-venter of abdomen more or less membranous. Distribution of dorsal secretions characteristic of species: dorsum and dorsal margin with white secretions distributed in regular transverse ridges on body segments, also forming 5 longitudinal lines, one median, 2 submedial and 2 submarginal to marginal; each longitudinal line separated by a space covered by a light coating of secretion (Fig. 1C). Posterior end of abdomen dorsally with a circular area, 1.7-2.3 mm in diameter, with derm covered by pores and setae, forming a plate that later is pushed out allowing adult female to protrude her abdomen (Fig. 14). Venter with powdery secretions; antennae and legs brownish-black. An external waxy tube, about $4-5 \mathrm{~mm}$ long, produced from anus.

Mounted specimens ( $\mathrm{n}=10)$. (Drawing [Fig. 11] made from preadults in poor condition). Body $8.0-10.5 \mathrm{~mm}$ long, $7.2-8.5 \mathrm{~mm}$ wide; derm on both dorsum and venter strongly sclerotised, with only a small part on medial venter membranous. Antenna 9 segmented, total length 640-670 $\mu \mathrm{m}$; each segment with a few setae 40-60 $\mu \mathrm{m}$ long; apical segment (Fig. 11A) about $135 \mu \mathrm{m}$ long, $70 \mu \mathrm{m}$ wide, with a long seta $100 \mu \mathrm{m}$ long, 4-6 shorter seta, each 55-80 $\mu \mathrm{m}$ long, and 3 fleshy setae, each 45-60 $\mu \mathrm{m}$ long. Eyespot 90-95 $\mu \mathrm{m}$ wide, lens about $50 \mu \mathrm{m}$ in diameter, situated lateral to antennal scape. Mouthparts well developed; clypeolabral shield 350-370 $\mu \mathrm{m}$ long; labium short, about $150 \mu \mathrm{m}$ long. Legs short and robust. Metathoracic leg: trochanter + femur about $480 \mu \mathrm{m}$ long, trochanteral seta about $80 \mu \mathrm{m}$ long plus 2 campaniform sensilla on each side; femur about $180 \mu \mathrm{m}$ wide, ventrally with setae 40-55 $\mu \mathrm{m}$ long; tibia about $280 \mu \mathrm{m}$ long, with few setae; tarsus about $190 \mu \mathrm{m}$ long, $50 \mu \mathrm{m}$ wide, ventrally with short setae; claw (Fig. $11 \mathrm{~K}$ ) robust, $60-65 \mu \mathrm{m}$ long, without denticle, with 1 pair of short setose digitules. Thoracic spiracles (Fig. $11 \mathrm{~N}$ ) each with atrium about $160 \mu \mathrm{m}$ wide and peritreme about $270 \mu \mathrm{m}$ wide; each spiracle with 45-50 perispiracular multilocular pores. Abdominal spiracles (Fig. 11C) numbering 7 pairs; each atrium about $75 \mu \mathrm{m}$ wide and with a group of 7-12 perispiracular multilocular pores (Fig. 11B), their number reducing toward posteriormost pair. Anal tube (Fig. 11E) about $350 \mu \mathrm{m}$ long and $75 \mu \mathrm{m}$ wide, inner end with about 6 rings of polygonal wax pores and distal end with 3-4 rings of multilocular pores; anal opening producing a long wax tube. Posterior end of dorsal abdomen with a large area of circular derm, about $1.5-2.5 \mathrm{~mm}$ wide, bearing (i) a few pores (Fig. 11G), (ii) a few hair-like setae (Fig. 11F1) and (iii) a dense covering of long spines (Fig. 11F2), each 80-90 $\mu \mathrm{m}$ long; whole surface surrounded by a sclerotised rim at maturity; this derm strongly sclerotised and transformed into a hard plate corresponding to future exit hole (see biological observations below, and Fig. 14).

Dorsum. Multilocular pores with a triangular centre and about 16 outer loculi (Fig. 11B), scattered on dorsum and around each peritreme. Similar multilocular pores but with a circular centre, mainly present on posterior end of abdomen (Fig. 11G). Clusters of spines each forming a "secreting area" (Fig. 11D), with (i) hair-like setae, (ii) spines and (iii) flagellate seta, in discrete zones on each segment of body; each larger cluster containing about 
100-150 mainly curved and pointed spines, mostly 30-35 $\mu \mathrm{m}$ long, but smaller clusters with about 20-40 spines; periphery of each cluster with hair-like and flagellate setae. These spines also scattered throughout dorsum but mostly broken, with only base visible and appearing as pore-like structures. Long spines most numerous, each straight with a pointed apex, about 70-90 $\mu \mathrm{m}$ long, densely distributed throughout on dorsum, mixed with less numerous and shorter (about 30-35 $\mu \mathrm{m}$ long) stout spines (Fig. 11L). Details of cicatrices difficult to discern due to dermal sclerotisation but probably similar to those on venter (Fig. 11J); larger cicatrix-like structures, each 40-70 $\mu \mathrm{m}$ across, with a rough surface, appear as clear windows in sclerotised derm [but these may be artifacts]. Disc-like tubercles not apparent.

Venter. Multilocular pores (Fig. 11G), each with a circular centre and with 10-11 outer loculi as on dorsum, scattered throughout. Hairs (Fig. 11M), each 90-100 $\mu \mathrm{m}$ long, with a swollen apex and an expanded base, present in medial area of thorax. Spines, both straight and curved (Fig. 11L), of two sizes, either 30-35 $\mu \mathrm{m}$ or about 70-90 $\mu \mathrm{m}$ long, as on dorsum, dense across body in transverse bands but not forming wide patches. Cicatrices difficult to discern; circular structures with a smooth surface (Fig. 11J), each 20-30 $\mu \mathrm{m}$ across, and larger cicatrix-like structures with a rough surface (Fig. 11I), scattered. Disc-like tubercles also difficult to discern but probably sparsely present (Fig. 11H).

First-instar nymph (Fig. 12). Mounted specimens ( $\mathrm{n}=10)$. Body elongate to oval, 1200-1400 $\mu \mathrm{m}$ long, 630-700 $\mu \mathrm{m}$ wide; derm membranous; spinules in transverse rows on each segment of ventral abdomen. Antenna 6 segmented, total length 660-710 $\mu \mathrm{m}$; antennal segments narrow, 30-35 $\mu \mathrm{m}$ wide, but lengths of segments very different, with pedicel about $160 \mu \mathrm{m}$ long and third segment only about $35 \mu \mathrm{m}$ long; pedicel with a campaniform sensillum distally; each antennal segment with long setae, 120-170 $\mu \mathrm{m}$ long, and a few shorter setae; apical segment (Fig. 12B) longest, about $195 \mu \mathrm{m}$ long, $50 \mu \mathrm{m}$ wide, with 7 or 8 setae, each 130-200 $\mu \mathrm{m}$ long, one about $270 \mu \mathrm{m}$ long, plus 4 fleshy setae, each about $50 \mu \mathrm{m}$ long. Eyespot situated posterolateral to antennal scape. Clypeolabral shield 350-375 $\mu \mathrm{m}$ long; labium 3 segmented, 230-250 $\mu \mathrm{m}$ long, apical segment with about 8 setae. Legs long and slender with few setae; prothoracic legs shorter than other legs. Metathoracic leg: trochanter + femur about $300 \mu \mathrm{m}$ long, trochanter with 2 campaniform sensilla on each side and with a long seta, about $110 \mu \mathrm{m}$ long; tibia about $370 \mu \mathrm{m}$ long and $26 \mu \mathrm{m}$ wide; tarsus about $200 \mu \mathrm{m}$ long, $20 \mu \mathrm{m}$ wide; claw with a denticle and a pair of setose digitules (Fig. 12M). Thoracic spiracles (Fig. 12O) each with atrium about $20 \mu \mathrm{m}$ wide, peritreme about 40 $\mu \mathrm{m}$ wide and with 2 or 3 perispiracular multilocular pores, each pore with 5 or 6 loculi in centre. Abdominal spiracles (Fig. 12G) small, numbering 7 pairs; each atrium about 12-14 $\mu \mathrm{m}$ wide and 16-18 $\mu \mathrm{m}$ long, without pores. Anal tube (Fig. 12I) about $65 \mu \mathrm{m}$ long, interior end with polygonal wax pores.

Dorsum. Multilocular pores (Figs 12A, J), each with 3-6 central loculi and 10-12 outer loculi, in transverse rows, 1 pore wide, on all body segments. Short flagellate and hair-like setae (Figs 12D, E), each 25-40 $\mu \mathrm{m}$ long, scattered on head, and in transverse rows on thorax and abdomen; a few longer setae, each 50-55 $\mu \mathrm{m}$ long, on head and thorax. Stout straight spines (Fig. 12H) present in a sparse transverse row on each segment of abdomen, dense on last abdominal segments where mixed with stout curved spines (Fig. 12H). Dense groupings of robust setae (Fig. 12F), each 80-95 $\mu \mathrm{m}$ long, present around anal opening. Disc-like tubercles (Fig. 12C) dense on marginal to submarginal areas around body, and forming submedial clusters on each side of head; also present in a dense transverse row, 1-3 tubercles wide, on each body segment, apart from last 4 segments where spines replace tubercles.

Venter. Multilocular pores (Figs 12L, N), each with 3 or 5 central loculi and 10-12 outer loculi, scattered on head and thorax and in a transverse row, 1 pore wide, on each abdominal segment. Submedial part of head with a few long setae (Fig. 12P), each about $120 \mu \mathrm{m}$ long; slender flagellate setae (Fig. 12R), each 40-55 $\mu \mathrm{m}$ long, scattered on submedial and submarginal areas mixed with shorter flagellate setae, each 25-35 $\mu \mathrm{m}$ long, on thorax and in transverse rows on abdomen. Margin of abdomen with 9 pairs of long setae: caudal setae (Fig. 12K) in 3 pairs, each $850-1000 \mu \mathrm{m}$ long, and rest of margin with 6 pairs, each $650-800 \mu \mathrm{m}$ long (Fig. 12T). In addition, posterior end with 2 pairs of hair-like setae (Fig. 12U), each $130 \mu \mathrm{m}$ long, and a pair of medial setae, each $80 \mu \mathrm{m}$ long, posterior to medial cicatrix. Cicatrices circular (Fig. 12S), each 33-35 $\mu \mathrm{m}$ in diameter, 3 in number, present medially on posterior end of abdomen. Disc-like tubercles absent.

Adult male (Fig. 13). Mounted specimens ( $\mathrm{n}=2$ ). Body large, $4.0-5.0 \mathrm{~mm}$ long, $1.30-1.33 \mathrm{~mm}$ wide across prealare. Body covered in many setae of 3 main types: (i) collared setae (cs) (Fig. 13E), each with a shallow collarlike basal socket but on a rounded mound, up to perhaps $100 \mu \mathrm{m}$ long; (ii) hair-like setae (hs) (Fig. 13F), each with a shallow basal socket around setal membrane and up to $50 \mu \mathrm{m}$ long, and (iii) hairs (hrs) (Fig. 13G), each with a cone-like base fused to seta and up to about $40 \mu \mathrm{m}$ long. Loculate pores (lp) (Fig. 13C) abundant, each about $10 \mu \mathrm{m}$ 
wide, with a star-like pattern with mainly 4 loculi; found almost wherever setae are present. Other pores of 3 types also present: (i) convex pores (cp) (Fig. 13A), each very convex, each $5 \mu \mathrm{m}$ tall and $5 \mu \mathrm{m}$ wide, on a shallow base, with a granulate surface, restricted to head; (ii) small heavily sclerotised pores (msp) (Fig. 13B), each about $3.5 \mu \mathrm{m}$ wide, present on head but possibly absent elsewhere, and (iii) barely sclerotised pores ( $\mathrm{mp}$ ) with a dark centre, each about $3 \mu \mathrm{m}$ wide, on thorax and abdomen. Antenna long, with long setae randomly distributed, each usually with satellite setae. Nodulations not noted on any sclerites. Scutum with a median membranous area with setae and pores. Legs well developed and setose, with many spur-like setae on tibia and tarsus, none bifurcate; tarsus 2 segmented (Fig. 13L); claw without a denticle; claw digitules setose. Abdominal segment I not visible ventrally; abdomen with a short, broad lateral caudal extension (Fig. 13I) on segment VIII, other abdominal segments somewhat bulbous marginally; abdomen without tubular ducts.

Head. Triangular in dorsal view, length about $625 \mu \mathrm{m}$, width across compound eyes 750-800 $\mu \mathrm{m}$. Dorsally with a well-developed postoccipital suture extending across posterior part of epicranium; with a broad postocciput posteriorly, without setae. Dorsomedial part of epicranium apparently entirely membranous, without a dorsal part to midcranial ridge. Dorsal surface with many setae, mainly cs but with some hs and hrs (cs up to about 80-90 $\mu \mathrm{m}$ long; hs up to $50 \mu \mathrm{m}$ long); and with many pores, both lp, cp (fewer than lp) and a few msp. Laterally with a pair of large compound eyes (cde), each about 270-365 $\mu \mathrm{m}$ long, with about 120 ommatidia. Each compound eye with a narrow, lightly sclerotised, ocular sclerite along dorsal and posterior margins, and a single ocellus situated dorsal to compound eye; width of each ocellus about $60-65 \mu \mathrm{m}$; each ocular sclerite with a narrow post-ocular ridge along dorsal margin; ventral projection not located. Ventrally with a strongly sclerotised series of ridges forming a fivearmed cross (Fig. 13O), composed of: (i) ventral midcranial ridge anteriorly; (ii) a pair of lateral preocular ridges, and (iii) a pair of preoral ridges (pror) posteriorly. Ventral part of epicranium membranous apart from some light sclerotisation in angle between vmcr and procr and between procr and pror; setae, lp and cp abundant anteriorly between ventral midcranial and preocular ridges but absent from between preocular and preoral ridges; area posterior to preoral ridge with hs and hrs setae and $1 \mathrm{p}$ around mouth. Cranial apophysis shallow and broad. No structures representing tentorial arms, tentorial bridge or tendon-like apodeme detected. Ventral sclerites present just posterior to each compound eye. Antenna: 10 segmented; length about $3.8 \mathrm{~mm}$ (ratio of total-body length to antennal length 1:0.84). Scape about $190 \mu \mathrm{m}$ long, $195 \mu \mathrm{m}$ wide, sclerotised, basal part with a sclerotised marginal ridge and with a strong basal articular process extending posteriorly from lateral margin of each scape; with about 25 setae, each about 65-80 $\mu \mathrm{m}$ long. Pedicel 215-250 $\mu \mathrm{m}$ long, $125-130 \mu \mathrm{m}$ wide, articulating with scape; with about 45 setae, of which about half very long, each about 270-330 $\mu \mathrm{m}$ long; others short as on scape, some with satellite setae, plus a large campaniform sensillum on dorsal surface. Segments III-IX each more or less parallelsided and about $70-105 \mu \mathrm{m}$ wide, broadest at segment III, narrowing towards apex; lengths ( $\mu \mathrm{m}$ ): III 315-380, IV 380-412, V 410-445, VI 410-430, VII 41-430, VIII 375-380, IX 285-315 and X 345; segments each with about 50-65 long setae, rather randomly distributed, plus a few hs; each long seta 185-350 $\mu \mathrm{m}$ long, with 0-3 satellite setae (Fig. 13N); antennal bristles barely differentiated from long setae, with $3+$ on apical segment; possibly present on some other segments but not differentiable from other setae; no basiconic sensilla or capitate setae noted on segment X.

Thorax. Prothorax: neck broad, with no indication of a cervical groove. Dorsally: pronotum absent. With a pair of diagonal post-tergites, each about $415 \mu \mathrm{m}$ long, broadest anteriorly. Laterally with a pair of strong cervical sclerites that articulate anteriorly with ventral sclerite and preoral ridge; cervical sclerites perhaps without a proepimeron. Pleural ridge short, extending dorsally from articulation with coxa; pleural apophysis distinct. Ventrally: prosternum with a well-sclerotised median ridge, about $500 \mu \mathrm{m}$ long, which broadens posteriorly but with no obvious sternal apophysis. Most membranous areas covered with abundant hs (about $60 \mu \mathrm{m}$ long), a few cs, hrs and lp, as follows: with a broad group of median pronotal setae and pores extending between post-tergites over anterior end of prescutum; a large group of lateral pronotal setae $+1 \mathrm{p}$ anteriorly; large groups of propleural setae and pores anteriorly and posteriorly on each side, possibly without any gap between groups; anteprosternal setae either absent or in a group fused with prosternal setae; with an elongate group of prosternal setae and pores on each side of prosternum; presence of antemesospiracular setae and lp uncertain. Mesothorax: dorsally: prescutum (prsc) large and oval (length 445-500 $\mu \mathrm{m}$, width 685-780 $\mu \mathrm{m}$ ); mesoprephragma short and narrow; prescutum not nodulated; prescutal ridges short; prescutal sutures well developed; prescutum without prescutal setae and $1 p$. Scutum (sct) without nodulations; with a large oval membranous area medially, 160-260 $\mu \mathrm{m}$ long, 455-495 $\mu \mathrm{m}$ wide, with many scutal setae (cs, each about 40-60 $\mu \mathrm{m}$ long; hs and hrs each about 25-35 $\mu \mathrm{m}$ long) and lp; and with many setae and $\mathrm{lp}$ on either side of scutellum and on either side of membranous area. Scutellum (scl) 
triangular; scutoscutellar sutures extending posterolaterally from scutal membranous area to postalare; length 380 $\mu \mathrm{m}$, width 700-715 $\mu \mathrm{m}$; each outer angle with a distinct oval membranous area; with about 15 scutellar setae but no lp. Membranous area immediately posterior to scutellum without setae or pores. Laterally: prealare (pra) elongate. Tegula (teg) with many tegular setae and a few $\mathrm{lp}$. Mesopleural ridge well developed, with a deep pleural apophysis. Episternum not nodulated. Ventrally: basisternum large, length 700-760 $\mu \mathrm{m}$, width $775-825 \mu \mathrm{m}$; with a poorly developed median ridge; without $\mathrm{lp}$ but with a line of setae medially on either side of median ridge; anteriorly without a marginal ridge but marginal ridge well-developed anterolaterally along border of lateropleurite; precoxal ridges well-developed, each with a short subepisternal ridge; furca (f) moderately narrow posteriorly, waisted, with quite long, stout arms, which diverge strongly; lateropleurite represented by a small narrow sclerotised area. Postmesospiracular setae and lp abundant laterally and posteriorly to mesothoracic spiracle, but with only setae medially. Mesothoracic spiracles large, width of each peritreme perhaps 180-220 $\mu \mathrm{m}$. Wing sclerites showing nothing distinctive. Metathorax: dorsally: metapostnotum present as a pair of large, roughly triangular, sclerites, which nearly fuse with tergite of abdominal segment I; metatergal setae (mts) represented by a band of longish setae + a few lp extending across median part of segment. Laterally: dorsospiracular setae and $\mathrm{lp}$ in a large group. Suspensorial sclerites present. Pleural ridge well developed, without a vestigial metapleural wing process extending anterodorsally from dorsal end; precoxal ridge well developed and extending about $255 \mu \mathrm{m}$ medioventrally; metepisternum without setae; metepimeron represented by a strong sclerotisation extending posterodorsally around metacoxae; without setae or lp. Ventrally: with a large group of antemetaspiracular setae $+1 p$; metasternum transverse, only lightly sclerotised but with large lateral apophyses. With a large group of postmesoprecoxal ridge setae and $\mathrm{lp}$ on each side; anterior and posterior metasternal setae and lp abundant. Postmetaspiracular setae abundant, with many lp. Posterior spiracles large, located below mesocoxae; width of each peritreme about $215 \mu \mathrm{m}$.

Wings. Large and well developed, length about $4.0 \mathrm{~mm}$, width about $1.8 \mathrm{~mm}$. Subcostal thickening well developed; wing anterior to subcostal thickening well sclerotised; rest of wing heavily sclerotised, with reticulated micro-ridges; with a line of about $28-30$ circular sensoria +26 alar setae extending distally from where radius and medial veins meet; alar fold faint. Alar lobe well developed and lightly sclerotised. Hamulohalteres (Fig. 13D) only lightly sclerotised, without a strong sclerotisation along anterior margin; length about 380-475 $\mu \mathrm{m}$, width 165-200 $\mu \mathrm{m}$; each with 4 or 5 hamuli (ha), each hamulus capitate and about 95-130 $\mu \mathrm{m}$ long.

Legs. Metathoracic legs (Fig. 13M) slightly longest. Coxa lengths: I 375-425; II 325-375; III 375-390 $\mu$ m; metacoxae with many setae. Trochanter (tr) + femur (fm) lengths: I 725-800; II 700-800; III 775-800 $\mu \mathrm{m}$; metatrochanter with many shortish setae +1 long flagellate seta; trochanter with a curved line of 4 round campaniform sensilla on each side; femur with many setae, mostly about 75-85 $\mu \mathrm{m}$ long; bifurcated setae absent. Tibia (ti) lengths: I 775-800; II 850; III 900-925; with long flagellate setae dorsally (length 190-210 $\mu$ ); bifurcated setae absent; with many tibial spurs (tspu) (Fig. 13M) distally, longest about 55-80 $\mu \mathrm{m}$ long; distal end with some small translucent pores. Tarsi (ta) 2 segmented (Fig. 13L: $\mathrm{ta}_{1}$ and $\mathrm{ta}_{2}$ ), proximal segment very short and triangular; lengths of $\mathrm{ta}_{1}+\mathrm{ta}_{2}$ : I 375; II 360-400; III 350-375; each with a tarsal campaniform sensillum; setae along ventral margin mainly spur-like; lateral and dorsal setae mainly short but longer than spur-like setae; tarsal spurs not differentiated from other spur-like setae; both sides of tarsus with many small translucent pores; with 2 fine setose tarsal digitules. Claws rather broad basally and curved, without a denticle; each about $125 \mu \mathrm{m}$ long, with 1 pair of fine setose digitules (cd).

Abdomen. With a rather bulbous, rounded caudal extension (bce; Fig. 13I) on abdominal segment VIII; all other abdominal segments also slightly rounded marginally. Narrow tergites (dat) present mediolaterally on anterior borders of all segments; sternites absent. Setal distribution not easy to see; dorsal abdominal setae abundant, in bands across segments, probably mostly hs, shorter than ventral setae, each 45-60 $\mu \mathrm{m}$ long; ventral abdominal setae also abundant but in broader bands than on dorsum; hs on ventral surface somewhat longer than on dorsum (mostly about $60-85 \mu \mathrm{m}$ long); hs ventrally about twice as frequent as hrs. Loculate pores frequent to abundant on both dorsum and venter. Minute unsclerotised pores occasional, at least pleurally; convex pores and small sclerotised pores not detected. Pleural setae and lp not apparently divided into dorsal and ventral pleural groups but indistinctly separated from dorsal (das) and ventral (vas) abdominal setae. Pleural setae mainly fairly short but some up to $125 \mu \mathrm{m}$ long. Abdominal spiracles (Fig. 13H) very difficult to locate but thought to be small and simple, with a sclerotised opening about $12 \mu \mathrm{m}$ wide; believed to be present laterodorsally on anterior margins of at least segments V-VII. 


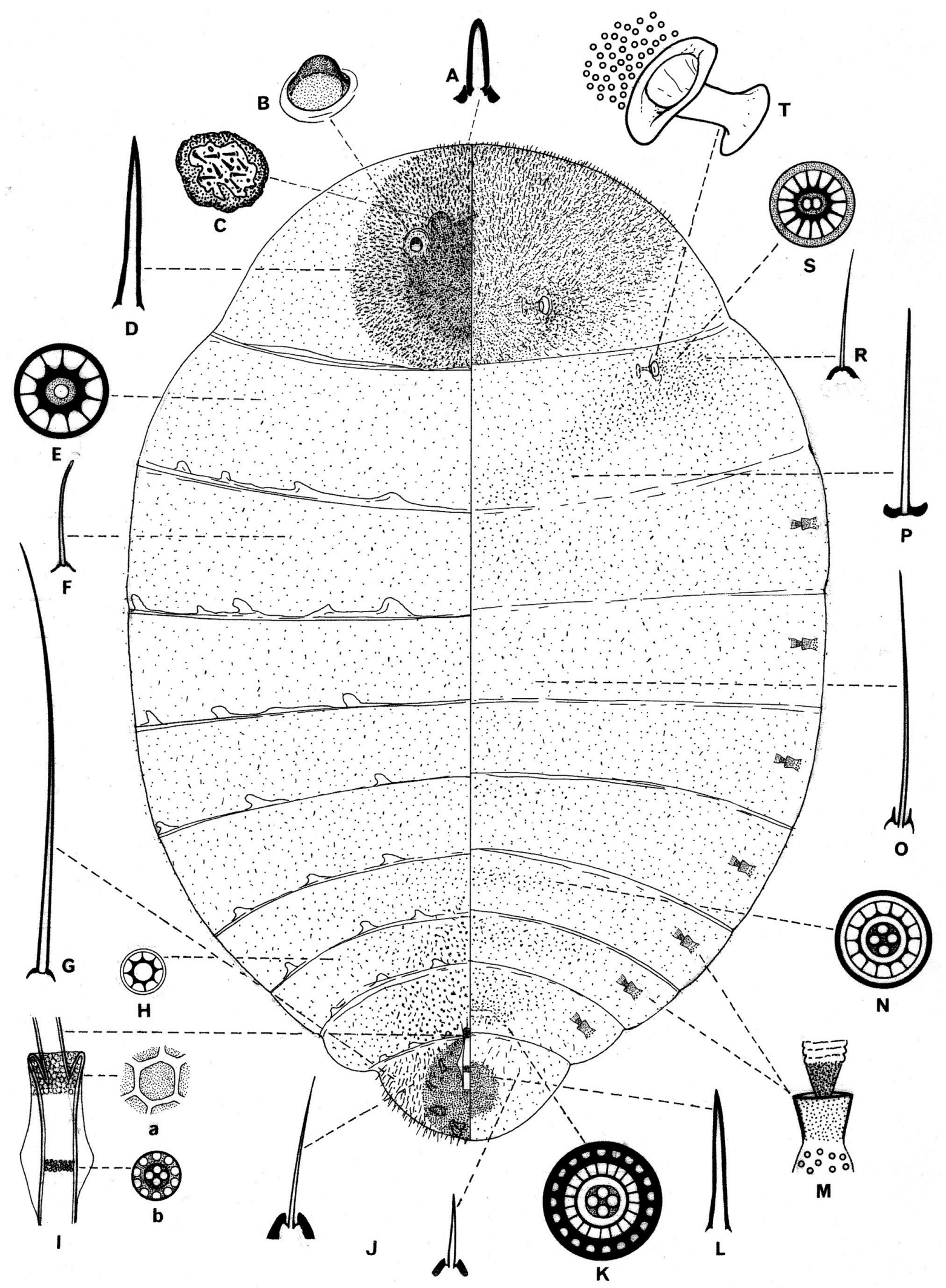

FIGURE 10. Mimosicerya schraderae (Vayssière). Adult female. A. short rounded spinose seta; B. eyespot; C. antenna; D. spine with pointed apex; E. dorsal multilocular pore; F. slender flagellate seta; G. long hair; H. multilocular pore with a wide circular centre; I. anal tube, $a=$ polygonal wax pore, $b=$ pore in anal tube; J. short hair-like setae; K. multilocular pore of large size with numerous loculi; L. spine at posterior end; M. abdominal spiracle; N. ventral multilocular pore; O. hair-like seta; P. flagellate seta; R. short, slender flagellate seta; S. multilocular pore common around spiracles and throughout venter; T. metathoracic spiracle with a large group of perispiracular multilocular pores. 


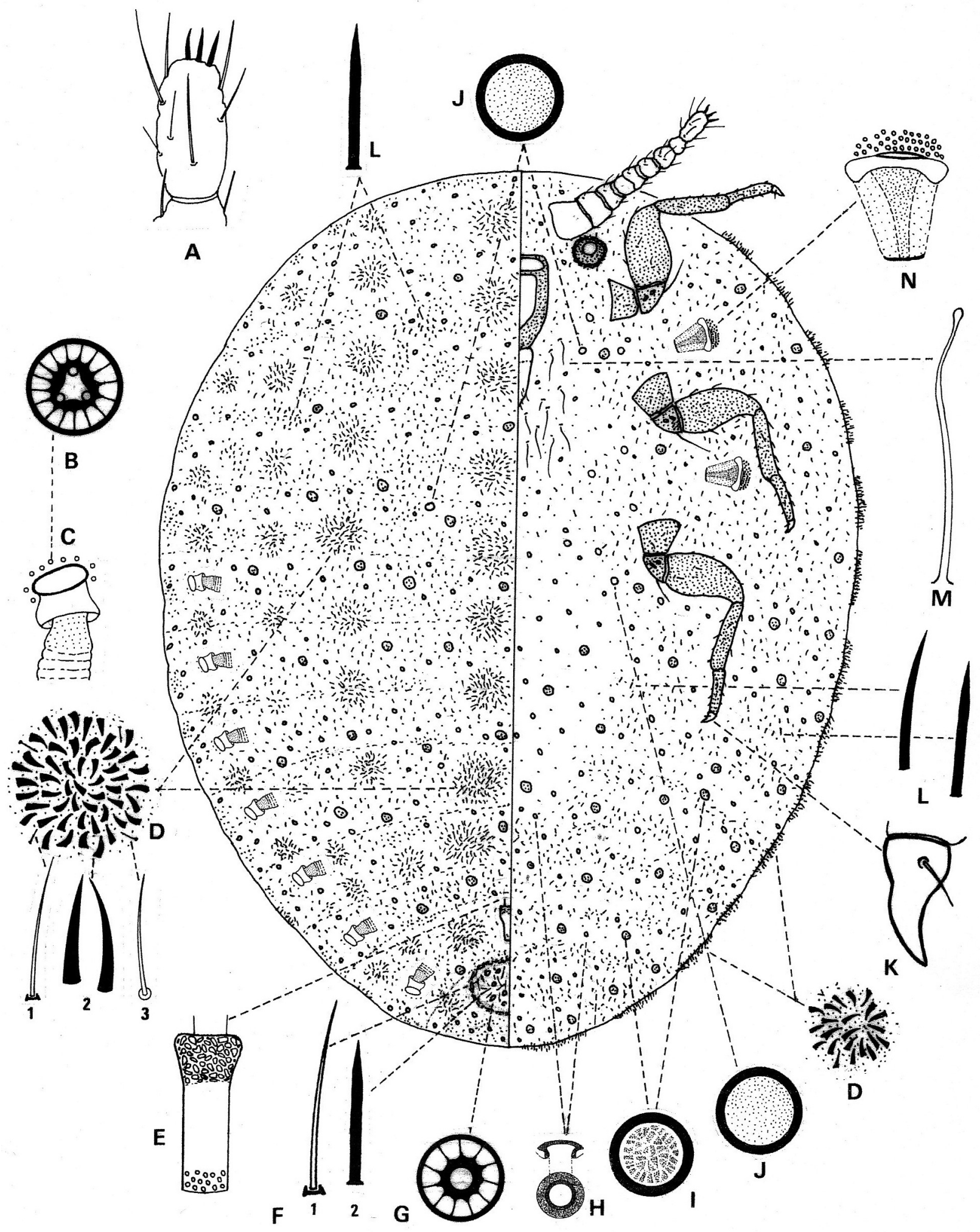

FIGURE 11. Mimosicerya schraderae (Vayssière). Third-instar female (preadult). A. apical segment of antenna; B. perispiracular multilocular pore of abdominal spiracle; C. abdominal spiracle; D. dorsal and marginal cluster of spines: 1 . hairlike seta, 2. spines, 3. flagellate seta; E. anal tube with polygonal wax pores at inner end and loculate pores distally; F. setation of large circular zone on dorsal posterior end of abdomen: 1. hair-like seta, 2. long spine; G. multilocular pore of circular zone; H. small disc-like tubercle appearing to have an open centre if viewed from above; I. thick-rimmed cicatrix with rough surface; J. thick-rimmed cicatrix with smooth surface, on dorsum and venter; K. claw of metathoracic leg; L. long straight and curved spines; M. hair with swollen apex and expanded base, restricted to medial thorax; N. mesothoracic spiracle with numerous perispiracular multilocular pores. 


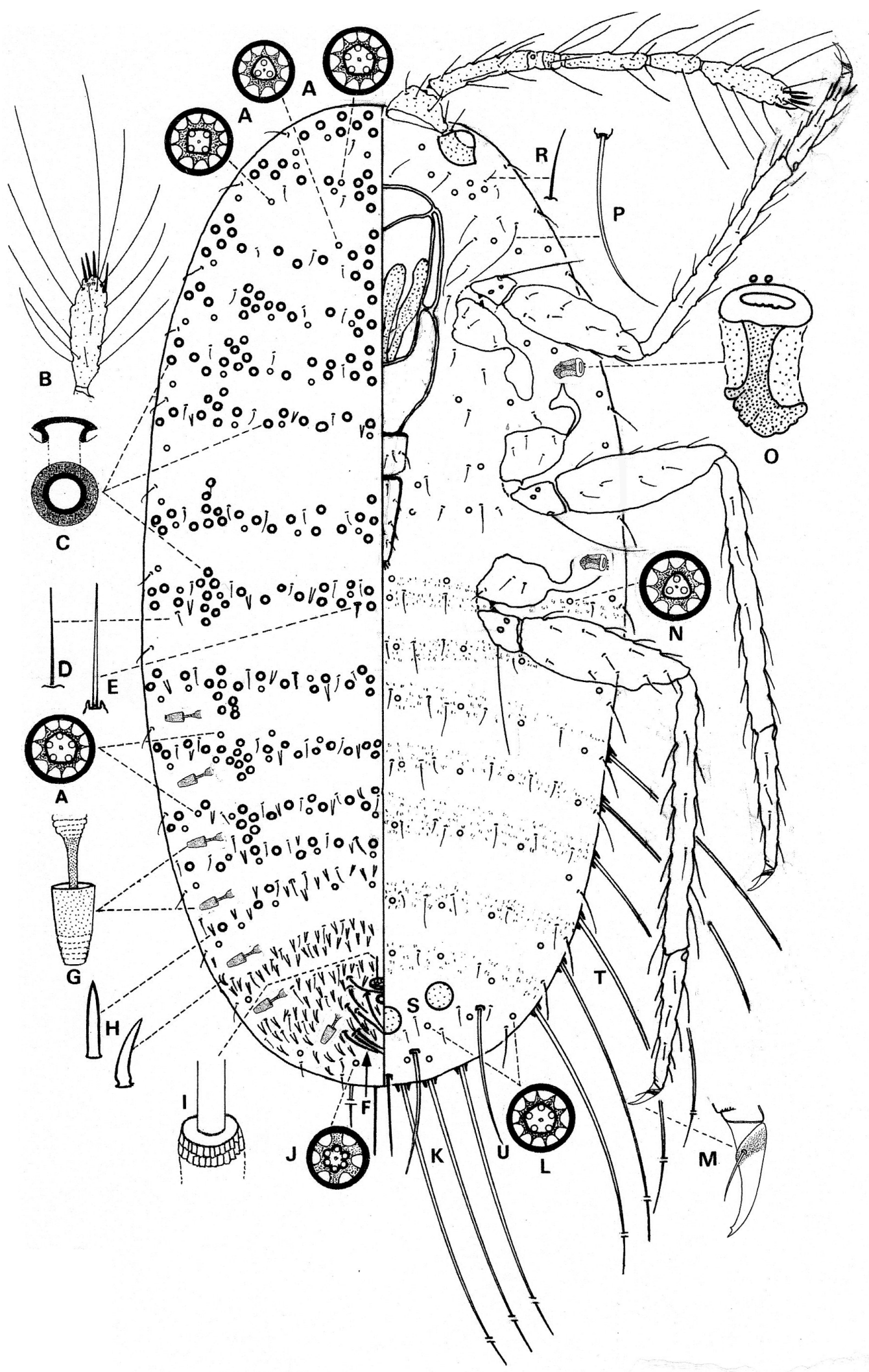

FIGURE 12. Mimosicerya schraderae (Vayssière). First-instar nymph. A. dorsal multilocular pores; B. apical segment of antenna; C. disc-like tubercle appearing to have an open centre if viewed from above; D. slender flagellate seta; E. hair-like seta; F. group of robust setae around anal area; G. abdominal spiracle; H. straight and curved spines; I. anal tube; J. multilocular pore with 6-locular centre; K. 3 pairs of long caudal setae; L. multilocular pore with 5-locular centre; M. metathoracic claw with a denticle; N. multilocular pore with 3-locular centre; O. mesothoracic spiracle with two perispiracular multilocular pores: P. slender hair-like seta; R. short flagellate seta; S. 3 ventral cicatrices. 


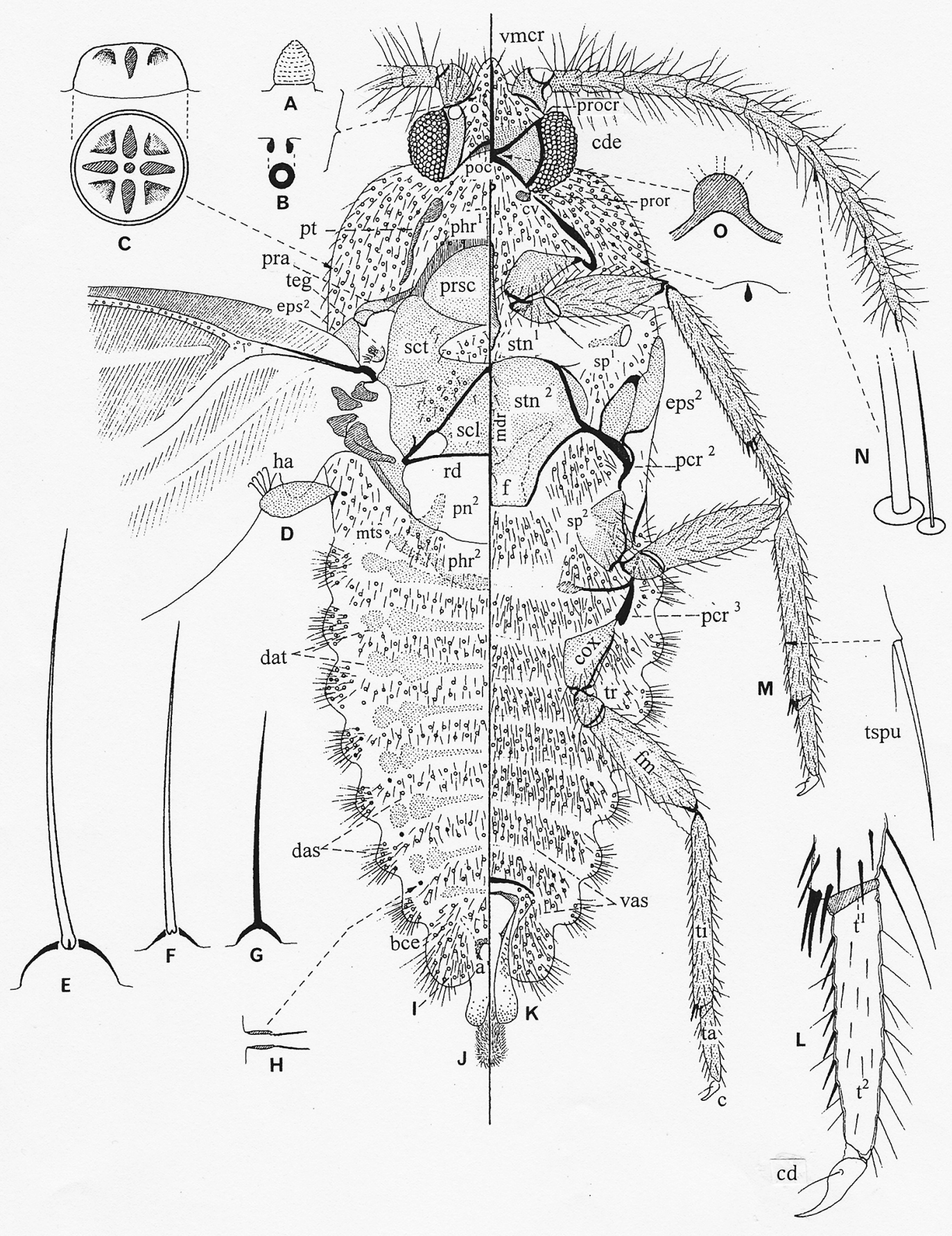

FIGURE 13. Mimosicerya schraderae (Vayssière). Adult male. A. convex pores restricted to head; B. heavily sclerotised pores on head; C. loculate pores, with a star-like pattern, abundant on both dorsum and venter; D. hamulohaltere with 4 hamuli (ha); E. collared seta on a wide bulbous base; F \& G. hair-like setae and hairs, more abundant on venter; H. abdominal spiracle; I. bulbous, rounded caudal extensions (bce) on abdominal segment VIII; J. setiferous endophallus; K. aedeagus; L. 2-segmented metathoracic tarsus $\left(\mathrm{ta}^{1}, \mathrm{ta}^{2}\right)$; M. metathoracic leg with tibial spurs ( $\mathrm{tspu}$ ), and flagellate setae but without bifurcated setae; N. antennal seta often with satellite seta(e); O. centre of a sclerotised series of ridges forming a five-armed cross. See 'Materials, methods and terminology' section for explanation of other abbreviations. 


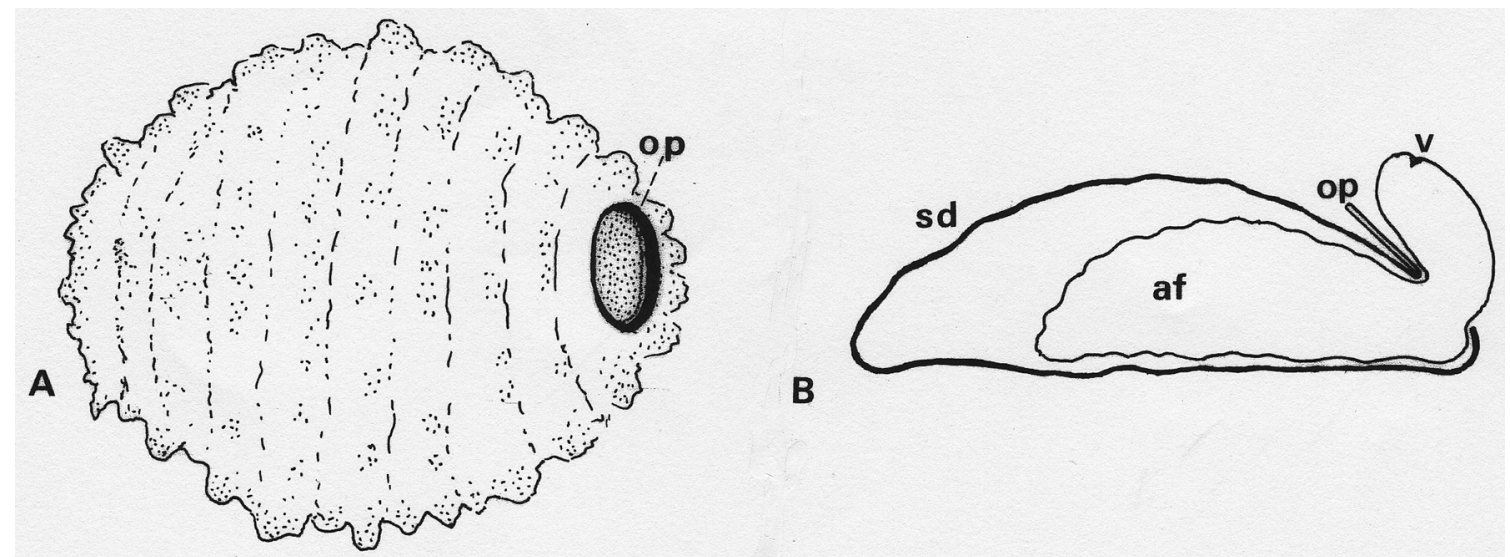

FIGURE 14. Schematic drawings of the preadult derm and the adult female of Mimosicerya schraderae (Vayssière) prior to and during mating (after Vayssière \& Hughes-Schrader, 1948): A. Dorsal view of the preadult exuviae showing the posterior end with a sclerotised anal operculum (op); B. position of the adult female (af) within the sclerotised derm (sd) of the preadult during mating, with the anal operculum pushed up and posterior abdomen of the adult pushed out to expose the vulva (v).

Genital segment. Anus present on dorsal surface above penial sheath, margin sclerotised and about 50-60 $\mu \mathrm{m}$ wide, with a slightly sclerotised triangular area extending anteriorly. Penial sheath sclerotised, about 750-790 $\mu \mathrm{m}$ long and 240-270 $\mu \mathrm{m}$ wide posteriorly, broadest anteriorly, where $305-310 \mu \mathrm{m}$ wide; penial sheath blunt and bifurcated posteriorly, with sparse short setae across dorsal surface, along margins and ventrally on either side of ventral opening, and with a group of small sensoria near apex. Aedeagus (Fig. 13K) possibly mainly membranous, length unknown, in a groove along ventral margin of penial sheath; with a very long, strongly setiferous, eversible endophallus (Fig. 13J).

Biological observations (Fig. 14). The following is a summary and translation from French of pages 66-73 from Vayssière \& Hughes-Schrader (1948).

Research on the life cycle was conducted under laboratory and field conditions, during the years 1937 to 1941. Nautococcus schraderae was collected on the island of Barro Colorado in the Panama Canal Zone during the dry periods of February 1937, December-January 1937-38, 1939-40, 1940-41; the preferred host plant was Annona spraguei (Annonaceae). It was collected also at Turrialba in Costa Rica, in February to March 1944, on Inga tonduzii (Fabaceae). In Panama, the preadult females were found on the trunk and the largest branches, mostly fixed in cracks or under bark. Frequently the second-instar male nymphs formed little groups of 4 to 20 individuals under bark or under the protective shelter constructed by ants. Third-instar males produced a white filamentous cocoon in which they developed to the adult stage.

Each adult female is enclosed within the strongly sclerotised preadult exuviae (Figs 1C, 14A), which frequently is covered by a protective shelter constructed by ants; an association with ants is frequently observed with this species. The posterior end of the dorsal abdomen of the preadult has a large area of circular derm surrounded by a sclerotised rim; at maturity, this derm is strongly sclerotised and transformed into a hard plate (operculum) that is pushed out by the adult female, through which she very slowly pushes out her posterior abdomen; this process can take some hours. Sometimes only the posterior end of the abdomen, but frequently about a third of the abdomen, extends from the preadult exuviae, and is directed upwards and anteriorly (Fig. 14B) and, in the laboratory, the attraction of males started immediately. The duration of mating varied considerably, between 8 to 126 minutes, with an average of 34 minutes, and males mated once, rarely twice, whereas the female could be mated successively by two different males. However, after mating, the female retracts its abdomen and stays within the preadult exuviae. Oviposition started from the seventh day after mating, was well advanced around days 12-13 and apparently finished by about day 14 . The eggs are laid within a network of filamentous wax secretions between the body of the female and the exuvial wall of the preadult. The period from oviposition to eclosion varied widely (48 and 66 days); the first-instar nymphs stay immobile inside the preadult exuviae for about two months after which they move out and settle on the trees. The most important cause of mortality of the females, nymphs and eggs was due to predators, particularly the larvae of coccinellids. Observations in the field and the laboratory suggest that there are two distinct, not overlapping, generations per year. This life cycle appears similar to those of Llaveia Signoret and Llaveiella Morrison, which also have two distinct generations per year. 
Vayssière \& Hughes-Schrader concluded that the placement of Nautococcus based on morphology (e.g., absence of legs and mouthparts in the adult female) was in the Coelostomidiinae (now family Coelostomidiidae), but, based on cytological results ( $2 \mathrm{n}$ female $=6$, male $=5$ ), it belonged to the Monophlebinae (now Monophlebidae).

\section{Neocoelostoma Hempel}

Neocoelostoma Hempel, 1932: 310. Type species: Neocoelostoma xerophila Hempel, by monotypy and original designation.

This genus was introduced by Hempel (1932) for Neocoelostoma xerophila Hempel, which he assigned to the Coelostomidiinae (now Coelostomidiidae) in the family Margarodidae sensu Morrison (1928). The species was described from a collection on Piptadenia falcata [now Anadenanthera peregrina var. falcata] (Fabaceae) obtained in 1931 in Pirapitinguy, São Paulo state, Brazil. Hempel's short description was based on the preadult female and the first-instar nymph and lacked any illustrations. The species was reported subsequently from Argentina, Bolivia and Paraguay on various Acacia species and on Parkinsonia praecox (Lizer y Trelles, 1936, 1939), and it has been recorded as the host of several chalcidoid wasp parasitoids (Noyes, 2012). Neocoelostoma remains monotypic, perhaps due to the difficulties of comparing newly collected material with the type material.

The life cycle of females of Neocoelostoma differs from that of Cryptokermes, Mimosicerya and Paracoelostoma in that the adult female is not retained within the test or exuviae of the preadult, as occurs in the other genera (Morrison, 1928; Vayssière \& Hughes-Schrader, 1948). In Neocoelostoma, the adult female escapes from the exuviae of the third-instar female via a circular opening at the anal end and then seeks a sheltered position on the bark where it exudes a mass of cottony white filaments prior to oviposition.

Generic diagnosis. This monotypic test-forming genus is restricted to Fabaceae. Most stages live exposed on the trunk or branches. It occurs in Argentina, Bolivia, Brazil, Paraguay and Uruguay. The fully-constructed test, enclosing the third-instar female, is up to $11 \mathrm{~mm}$ long and $8.5 \mathrm{~mm}$ wide, with an apical orifice about $2 \mathrm{~mm}$ in diameter. The test varies from light yellow to red-brown and has a rough texture on the outer surface, whereas the internal surface is smooth and coated with a thin layer of powdery white wax.

Adult female. Body broadly oval, posterior end rounded; derm membranous. Antenna 11 segmented, each segment with numerous setae. Eyespot situated lateral to antennal scape. Mouthparts absent. Legs well developed, each with a large apodeme and with setae on all segments; trochanter with 3 or 4 campaniform sensilla on each side; inner edges of tibia and tarsus with stout setae; claw stout and curved without a denticle. Thoracic spiracle without atrial pores but each peritreme with perispiracular multilocular pores. Abdominal spiracles numbering 7 pairs; atria of anterior spiracles with pores. Vulvar opening indistinct, near end of abdomen. Anal tube poorly developed and anal opening lightly sclerotised. Dorsal multilocular pores circular or broadly oval, with a thickened rim, each mostly with an oval bilocular centre and 10-12 outer loculi, scattered on head, thorax and abdomen; some smaller pores, each up to $8 \mu \mathrm{m}$ in diameter, along intersegmental lines. Ventral multilocular pores as on dorsum except pores on posterior segments of abdomen, particularly around vulva, with a circular or irregularly oval centre and mostly with 9-13 outer loculi. Dorsal and ventral setae fairly evenly distributed over surface, covered with abundant hairs, hair-like and flagellate setae. Cicatrices and disc-like tubercles absent.

Third-instar (preadult) female. Enclosed in a resinous test with a thin wall. Body almost round to ovoid; derm membranous except posterior end that has a large circular, strongly sclerotised, anal disc bearing scattered multilocular pores and setae. Antenna short, conical, 8 or 9 segmented. Eyespot located posterolateral to antennal scape. Mouthparts well developed; labium 3 segmented; basal segment narrow and difficult to discern. Legs considerably reduced, but each segment present; trochanter with 3 campaniform sensilla on each surface. Thoracic spiracles with each peritreme surrounded by numerous perispiracular multilocular pores. Abdominal spiracles numbering 7 pairs, with 2 posteriormost pairs smallest; each atrium with many multilocular pores. Dorsum and venter covered in multilocular pores, mostly with a trilocular centre and 8-12 outer loculi. Derm covered by mainly hair-like and flagellate setae. Cicatrices, mostly $15-35 \mu \mathrm{m}$ in diameter, present throughout dorsum and venter apart from anal area and medially on anterior thorax. Disc-like tubercles, each 7-8 $\mu \mathrm{m}$ in diameter, with a thick sclerotised rim and a slightly domed centre, distribution similar to cicatrices except present throughout ventral thorax.

Second-instar nymph. Similar to third-instar female but setae and pores less abundant. Body ovoid; derm 
membranous except posterior end of body strongly sclerotised, forming an anal disc bearing multilocular pores and setae and with a central anal opening. Antenna 5-7 (mostly 6) segmented. Eyespot situated posterolateral to antennal scape. Mouthparts well developed. Legs present, each segment reduced, total length about $260 \mu \mathrm{m}$. Thoracic spiracles with each peritreme surrounded by perispiracular multilocular pores. Abdominal spiracles numbering 7 pairs, with posteriormost 3 pairs smallest; each atrium with a few multilocular pores. Dorsal and ventral multilocular pores mostly with an oval or triangular centre. Derm covered by short setae, mainly hair-like and flagellate, longest at extremity of abdomen. Cicatrices, each 15-25 $\mu \mathrm{m}$ in diameter, present on all segments of dorsum and venter except anal area. Disc-like tubercles, each 7-8 $\mu \mathrm{m}$ in diameter, with distribution similar to cicatrices.

First-instar nymph. Body elliptical; derm membranous apart from a large sclerotised anal disc at posterior end with anal opening and multilocular pores and setae. Antenna 6 segmented, all segments with hair-like setae; apical segment also with fleshy setae. Labium 3 segmented, elongate. Eyespots sclerotised, each almost as large as first antennal segment. Labium 3-segmented. Legs long; claws slender, each with a pair of setose digitules and a denticle near apex. Thoracic spiracles each with 2 or 3 perispiracular multilocular pores. Abdominal spiracles numbering 7 pairs; atria with characteristic corrugated surface, but pores absent. Anal tube with polygonal wax glands at inner end. Derm with multilocular pores mostly each with a trilocular or quadrilocular centre and with scattered short setae. Posterior end of abdomen with 2 pairs of long caudal setae, each about 350-450 $\mu \mathrm{m}$. Venter with 3 large circular cicatrices on posteromedial abdomen. Dorsum with scattered small disc-like tubercles, each tubercle domed in centre.

Adult male. Derm of membranous areas of dorsum and venter mostly covered with numerous setae, mostly hair-like (hs) and flagellate setae (fs) and with convex loculate pores (lc), convex pores (cp) and small sclerotised pores (ssp). Antenna 10 segmented without nodes; segments with randomly distributed setae; many setae with satellite setae; minute setae present on intersegmental membranes between segments IV-VI; pedicel with a campaniform sensillum distally. Ventral mid-cranial ridge complete. Scutum with a membranous area medially with hair-like scutal setae, but without loculate pores. Legs well developed and very setose, many setae spur-like and some bifurcate, particularly distally on all tibia and posterior surface of profemur; each trochanter probably with 4 round campaniform sensilla on each side; tarsus 2 segmented; claw elongate, without a denticle; claw digitules setose. Abdominal spiracles probably numbering 7 pairs. Posterior margin of basisternum from which furca arises unusually narrow; basisternal setae numerous. Hamulohalteres each with 6-9 hamuli. Abdomen with pairs of long lateral extensions on segments VI, VII and VIII; endophallus eversible and spinose; aedeagus lightly sclerotised, lying in a ventral groove along penial sheath.

\section{Neocoelostoma xerophila Hempel}

Neocoelostoma xerophila Hempel, 1932: 311; Lizer y Trelles, 1936: 116; Lizer y Trelles, 1939: 174.

Adult female (Fig. 15). Note. There are no adult female type specimens of this species, but adult females of a species that appeared to be $N$. xerophila were available, collected in Argentina and Uruguay. In order to confirm the identity of the latter adult females, we compared the third-instar females from Brazil described by Hempel with third-instar females collected with the adult females from Argentina and Uruguay. The third-instar females from all three countries appear to be identical and thus below we describe the adult female of $N$. xerophila based on these specimens from Argentina and Uruguay.

Material examined. ARGENTINA: Provincia de Salta, Ruta 68, Quebrada del Rio de las Conchas, roadside, $26^{\circ} 03^{\prime} \mathrm{S}, 65^{\circ} 53^{\prime} \mathrm{W}$, on stem of Parkinsonia praecox (Fabaceae), 20.x.2011, T. Kondo coll., 2 adult females on 2 slides prepared by P. Gullan, 2012 (IMLA); Provincia de Salta, Rt. 34.4 mi S. Jujuy-Salta Border, on Acacia aroma (Fabaceae), 31.v.1977, H.A. Cordo coll., 2 adult females on 1 slide (USNM). URUGUAY: Montevideo, on Acacia sp., 12.xii.1921, P. Schurman coll., 1 adult female (USNM); Montevideo, on black acacia, 26.x.1927, A. Frujillo Teluffo coll., 1 adult female (USNM).

Mounted specimens $(\mathrm{n}=6)$. Body elongate ovoid, 7.0-10.7 mm long, 4.5-6.0 mm wide. Antenna 11 segmented, each 880-1350 $\mu \mathrm{m}$ long, each segment short and wide, with numerous setae, each seta $60-220 \mu \mathrm{m}$ long; scape $85-110 \mu \mathrm{m}$ long, $360-500 \mu \mathrm{m}$ wide with about 10 setae; membranous apex of pedicel with a circular 
campaniform sensillum; other segments short, narrowing to apical segment (Fig. 15A), latter 60-80 $\mu \mathrm{m}$ wide, 105 $160 \mu \mathrm{m}$ long, with $10-12$ setae, each 60 to $180 \mu \mathrm{m}$ long, and 4 or 5 fleshy setae about $50 \mu \mathrm{m}$ long. Eyespot circular, situated at base of antenna. Mouthparts absent, except present in specimen collected at Montevideo on Oct. 26, 1927 (might be retained from preadult). Legs small relative to body size. Metathoracic leg: coxa 320-380 $\mu \mathrm{m}$ long; trochanter + femur 700-950 $\mu \mathrm{m}$ long; trochanter with 3 or 4 small campaniform sensillum on each side and with a long trochanteral seta, 250-320 $\mu \mathrm{m}$; femur 240-410 $\mu \mathrm{m}$ wide; tibia 500-700 $\mu \mathrm{m}$ long, with robust setae, each 60-80 $\mu \mathrm{m}$ long, on ventral surface; tarsus (Fig. 15J) 250-430 $\mu \mathrm{m}$ long, with robust setae, each 40-60 $\mu \mathrm{m}$ long, on ventral surface; claw 110-150 $\mu \mathrm{m}$ long with a pair of setose digitules, each 60-80 $\mu \mathrm{m}$ long, but no denticle. Thoracic spiracles (Fig. 15M) each with spiracular opening 90-95 $\mu \mathrm{m}$ wide, peritreme 215-225 $\mu \mathrm{m}$ wide, and spiracular apodeme 220-230 $\mu \mathrm{m}$ long; each with a group of 15-20 perispiracular multilocular pores, each $10 \mu \mathrm{m}$ wide with oval centre, lateral to peritreme. Abdominal spiracles (Fig. 15F) numbering 7 pairs; anterior spiracles with atrium 100-120 $\mu \mathrm{m}$ wide, $70-80 \mu \mathrm{m}$ long, but becoming smaller towards posterior abdomen, with atrium of posteriormost pair 60-70 $\mu \mathrm{m}$ wide and about $50 \mu \mathrm{m}$ long; each spiracle with an inner sclerotised atrium and a short outer membranous atrium; spiracle connected to trachea by a short sclerotised tube; outer atrium with apparently with 8-12 multilocular pores (often hard to discern). Intersegmental lines of thoracic and abdominal segments sclerotised in mature females, each with small pocket-like apodemes (Fig. 15I). Spinules present ventrally on medial thorax and on abdominal segments. Vulvar opening membranous, positioned near posterior end of body and with a small apodeme at each extremity. Anal opening dorsal and anal tube membranous.

Dorsum. Multilocular pores (Fig. 15B), each 11-13 $\mu \mathrm{m}$ wide, circular to apparently slightly oval, with an oval bilocular centre and mostly 9-12 outer loculi, evenly distributed throughout dorsum. A few similar but smaller pores, each 8-10 $\mu \mathrm{m}$ in diameter with 6-9 outer loculi, present around anal opening only. Small pores few, along intersegmental lines on abdominal segments (Fig. 15E). Dorsum densely covered with flagellate setae (Fig. 15C), each mostly $70-140 \mu \mathrm{m}$ long, and hair-like setae (Fig. 15D), each 150-300 $\mu \mathrm{m}$ long, distributed throughout and along margin.

Venter. Multilocular pores as for main dorsal pores (Fig. 15B), each 10-13 $\mu \mathrm{m}$ wide, distributed throughout venter except on posterior abdomen; also with some similar pores with 6 central loculi (Fig. 15K). Multilocular pores (Fig. $15 \mathrm{H}$ ), each with a circular centre and mostly 9-12 outer loculi, densely distributed on posterior segments of abdomen, particularly in vulvar region. Small pores (Fig. 15E) similar to those on dorsum, present along intersegmental lines. Venter densely covered throughout with 2 types of seta: (i) flagellate setae (Fig. 15C), each 75-130 $\mu \mathrm{m}$ long, and (ii) hair-like setae (Fig. 15D), each 150-300 $\mu \mathrm{m}$ long; longest setae up to $450 \mu \mathrm{m}$ along margin.

Third-instar (preadult) female (Figs 1D, E, 16). Note. The description, measurements, and drawing are based on specimens from Argentina, Brazil and Uruguay. We also examined several photographs of morphological details made from 2 slides of syntype preadult females, labelled "Instituto Biológico / Neocoelostoma / xerophila H. [or 'Hemp.'] / sp. n. Type. / Coll. A. Hempel / R. 6. III: 31 [or just '6']”, from IBSP, São Paulo, Brazil, made available by Dr A.L.B.G. Peronti of Universidade Federal de São Carlos, Brazil. A specimen on one of these original Hempel slides should be designated the lectotype, but we do not take this action here because we have not personally seen the IBSP specimens.

Type material examined. BRAZIL: State of São Paulo, Pirapitinguy, on angico do campo, Piptadenia falcata Benth. [now Anadenanthera peregrina var. falcata (Fabaceae)], 6.iii.1931, Adolph Hempel coll., labelled as "cotype material", one slide of remains of dry female prepared by P.J. Gullan in 2009 , no other insect specimens in box (USNM).

Other material examined. ARGENTINA: Provincia de Salta, Ruta 68, Quebrada del Rio de las Conchas, roadside, $26^{\circ} 03^{\prime} \mathrm{S}, 65^{\circ} 53^{\prime} \mathrm{W}$, on stem of Parkinsonia praecox (Fabaceae), 20.x.2011, T. Kondo coll., 2 slides, each with one specimen, prepared by P. Gullan 2012 (1 IMLA, 1 USNM); Provincia de Tucumán, Valle Calchaquí, off Ruta $40,26^{\circ} 38^{\prime} \mathrm{S}, 66^{\circ} 02^{\prime} \mathrm{W}, 1850 \mathrm{~m}$., ex test on twig of P. praecox, 22.ii.2010, P.J. Gullan coll., 1 slide with one specimen prepared by P. Gullan, 2010 (IMLA). URUGUAY: Montevideo, on Acacia sp. (Fabaceae), Oct. 31, 1940, H.L. Parker coll., $\mathrm{N}^{\circ} 159$, one slide with one specimen (USNM); Montevideo, on black acacia, Oct. 26. 1927, A. Frujillo Teluffo coll. one slide with one specimen (USNM); Montevideo, on Acacia farnesiana or Parkinsonia aculeata, 1-17.xi.1943, Parker \& Berry coll., S. Amer. Parasite Lab. N 865, 3 slides, each with a preadult female, prepared from dry material by P.J. Gullan in 2009 (USNM). 


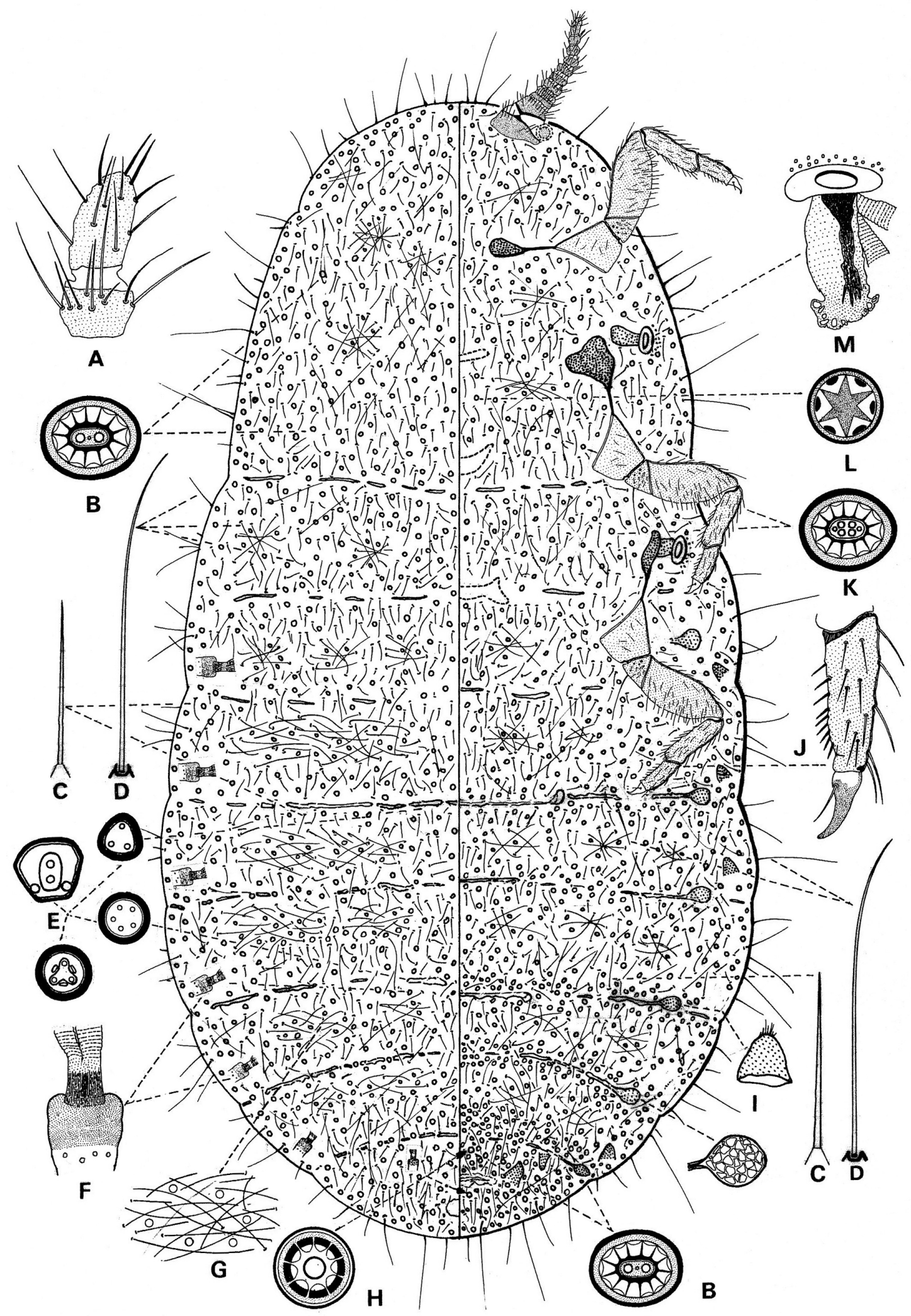

FIGURE 15. Neocoelostoma xerophila Hempel. Adult female. A. apex of antenna; B. multilocular pore with oval centre; C. dorsal flagellate seta; D. hair-like seta; E. small pores along intersegmental line; F. abdominal spiracle; G. grouping of long setae; H. multilocular pore with circular centre around vulvar opening; I. pocket-like marginal invagination, part of intersegmental line; J. tarsus and claw of metathoracic leg; K. multilocular pore with a large oval central loculus; L. 6-locular pore; M. mesothoracic spiracle with perispiracular multilocular pores. 


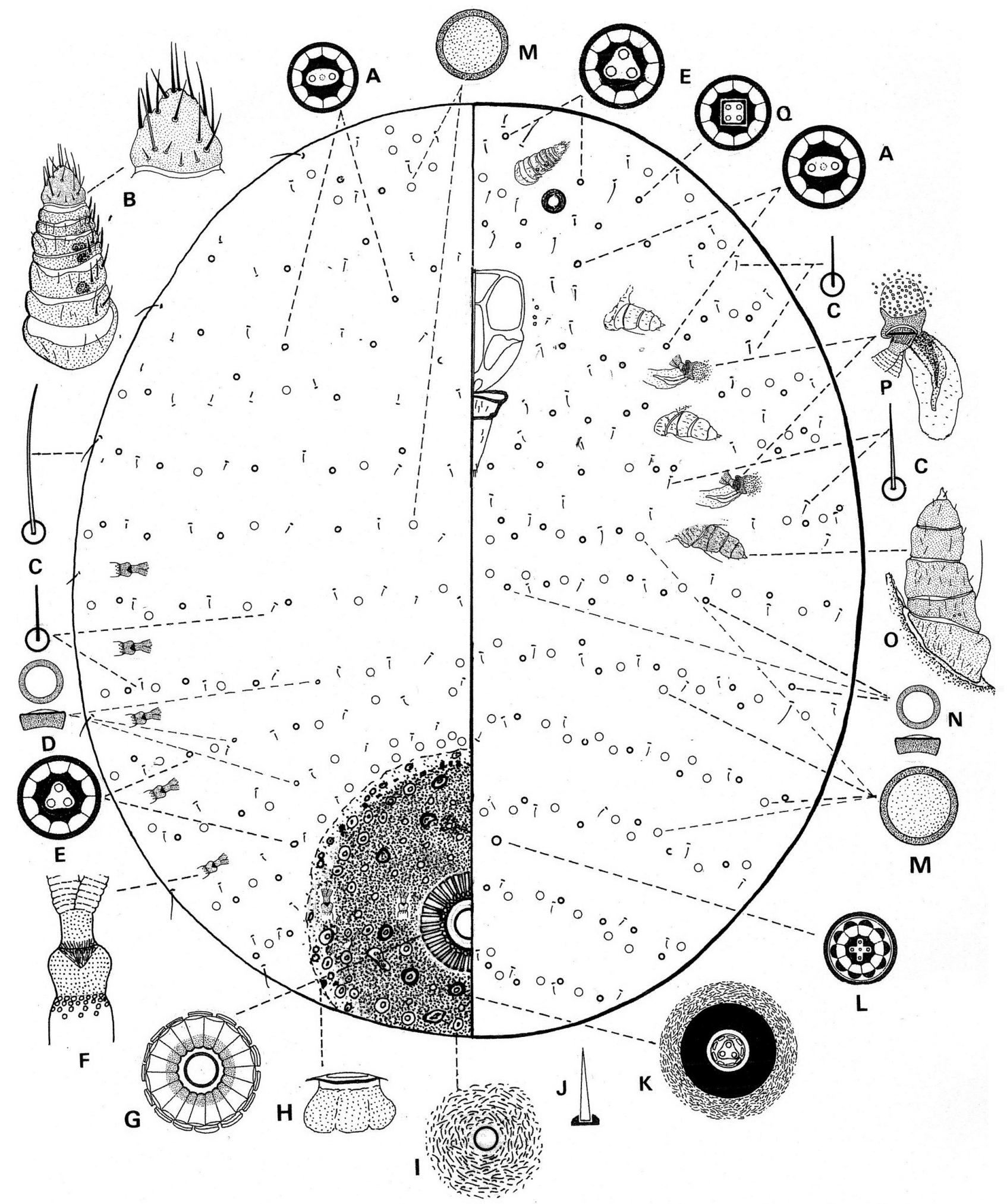

FIGURE 16. Neocoelostoma xerophila Hempel. Third-instar female (preadult). A. multilocular pore with oval bilocular centre; B. antenna and apical segment; C. flagellate and minute setae; D. disc-like tubercle; E. multilocular pore with trilocular centre; F. abdominal spiracle; G. elongated pores around anal opening; H and I. sac-like pore and wide simple pore on anal disc; J. stout hair-like seta on anal disc; K. raised pore on anal disc; L. multilocular pore with cruciform quadrate centre; M. cicatrix; N. disclike-tubercle; O. metathoracic leg; P. thoracic spiracle with dense perispiracular pores; Q. multilocular pore with quadrilocular centre. 


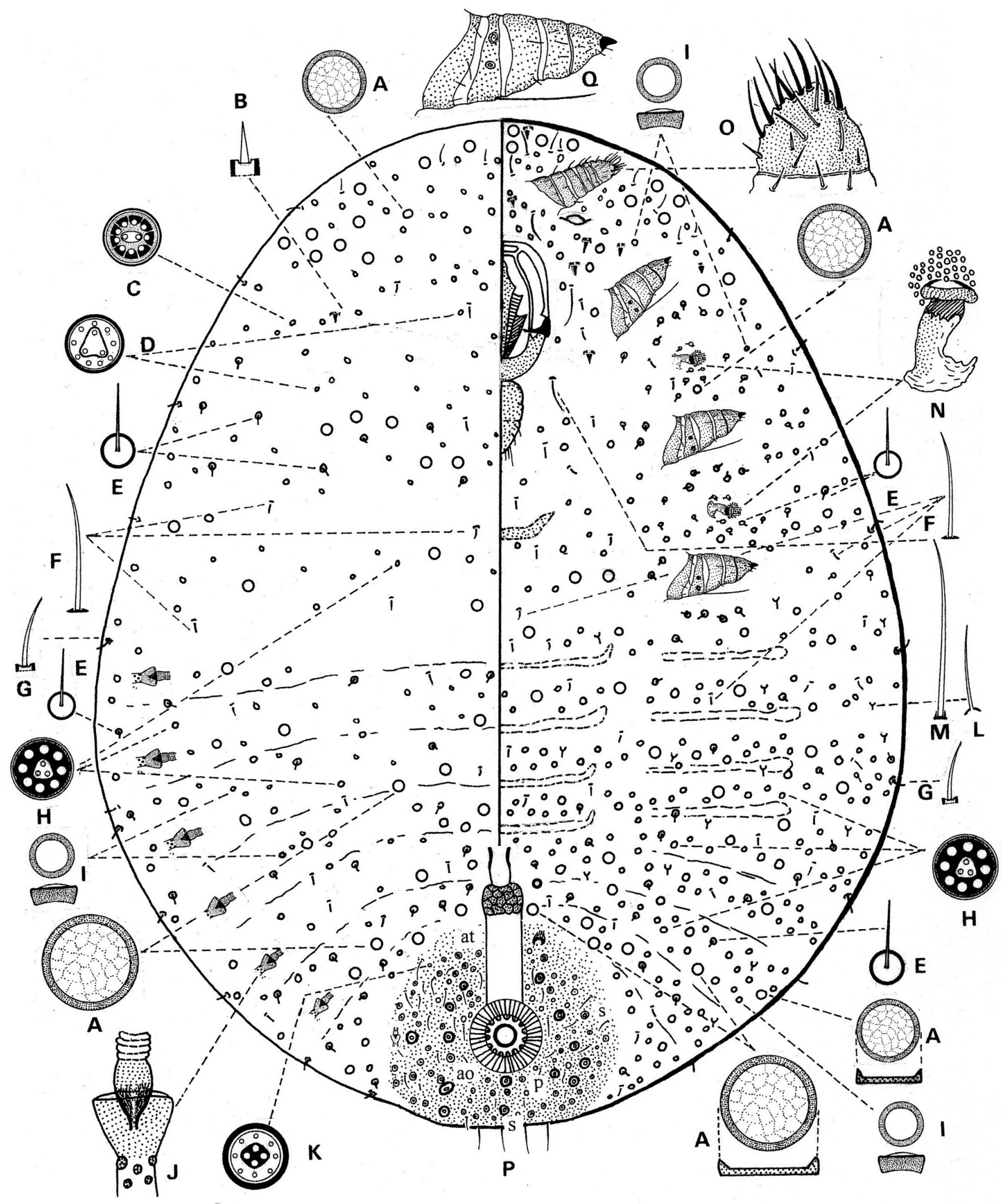

FIGURE 17. Neocoelostoma xerophila Hempel. Second-instar nymph. A. cicatrix; B. short stout seta; C. dorsal multilocular pore with oval centre; D. multilocular pore with trilocular centre; E. minute seta; F. flagellate seta; G. stout and curved hair-like seta on margin; H. multilocular pore with trilocular centre; I. disc-like tubercle; J. abdominal spiracle; K. multilocular pore with quadrilocular centre; L. flagellate seta; M. long hair-like seta on thorax; N. thoracic spiracle with perispiracular multilocular pores; O. apical segment of antenna; P. sclerotised anal disc with anal tube (at), anal opening (ao) pores (p) and setae (s); Q. metathoracic leg. 


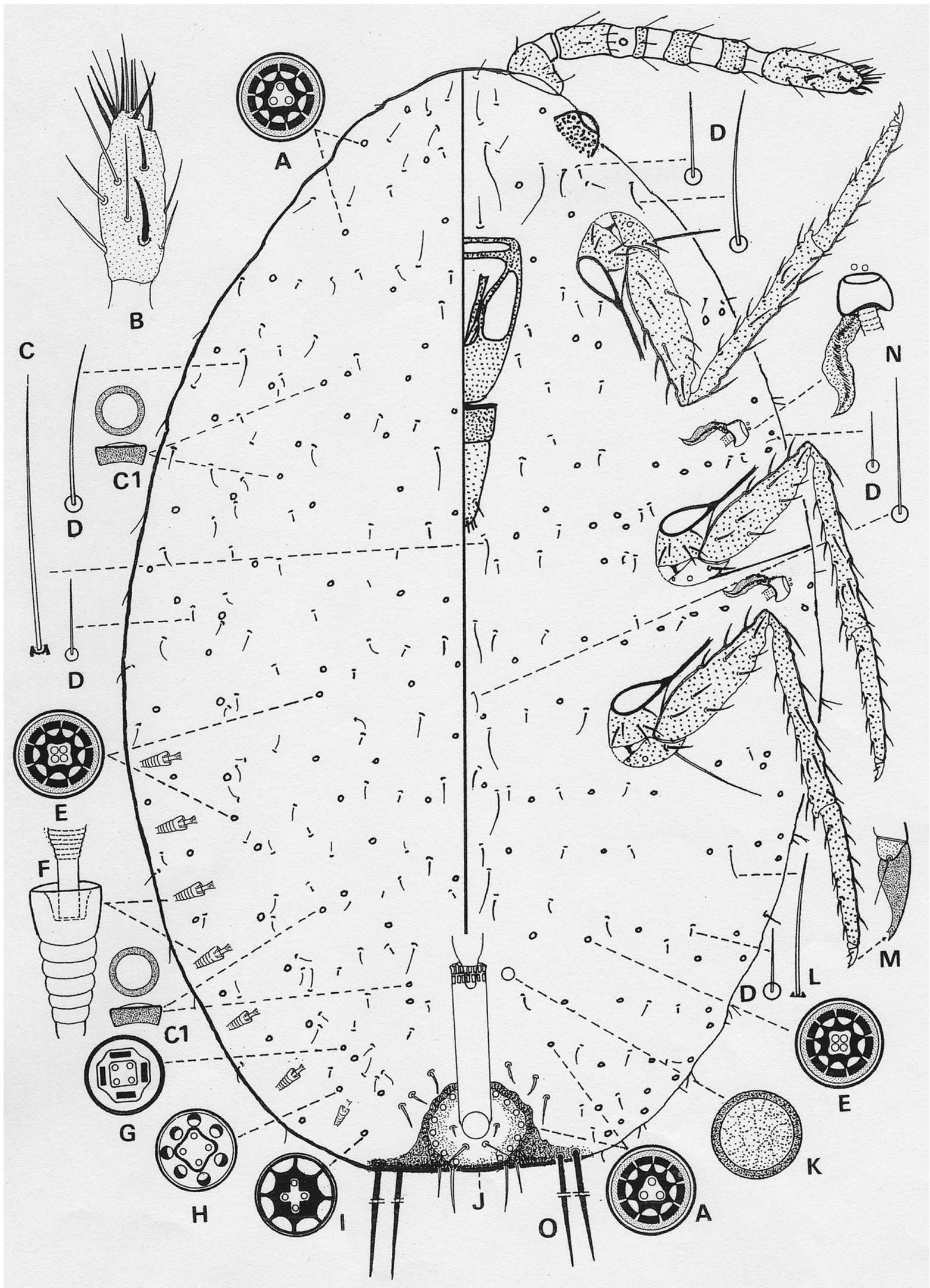

FIGURE 18. Neocoelostoma xerophila Hempel. First-instar nymph. A. multilocular pore with trilocular centre; B. apical segment of antenna; C. hair-like seta; C1. disc-like tubercle; D. flagellate setae; E. multilocular pore with quadrate centre; F. abdominal spiracle; G. pore with quadrilocular centre; H \& I. two types of multilocular pore with quadrate centre; J. anal disc with anal tube surrounded by a ring of pores and setae; K. cicatrix; L. hair-like setae on venter; M. claw with a denticle near apex; N. mesothoracic spiracle with 2 perispiracular multilocular pores. O. 2 pairs of long caudal setae. 


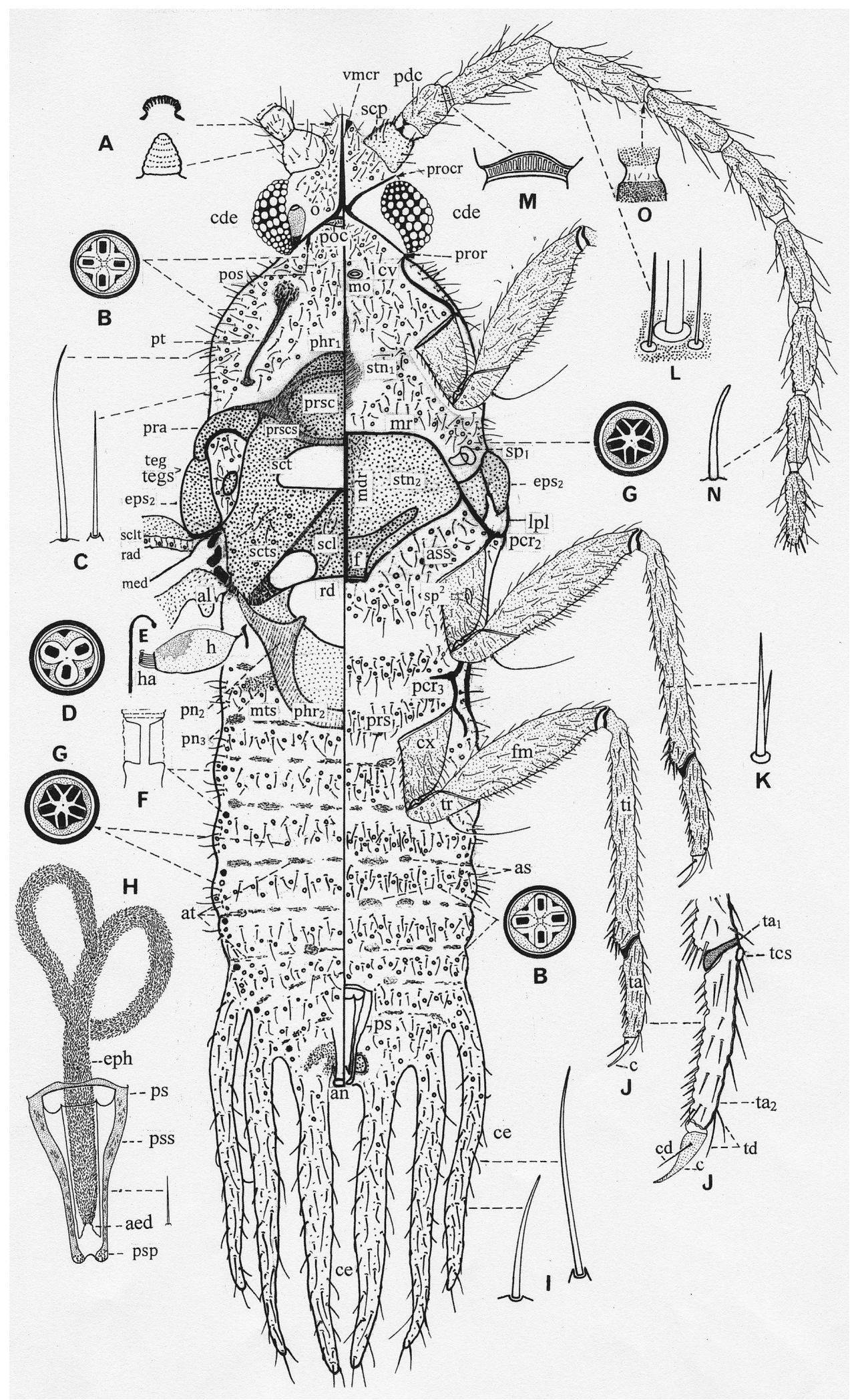

FIGURE 19. Neocoelostoma xerophila Hempel. Adult male. A. small conical and round pores on epicranium; B. quadrilocular pores on dorsum and venter; C. hairs and shorter hair-like setae; D. dorsal trilocular pores; E. hamulohaltere (h), with 6-7 hamuli (ha); F. abdominal spiracle; G. quinquelocular pores on dorsum and venter; H. setiferous endophallus and genital structures; I. hair-like setae; J. metathoracic leg and details of 2-segmented tarsus $\left(\operatorname{ta}^{1}\right.$, $\left.\operatorname{ta}^{2}\right)$, proximal part of $\mathrm{ta}^{2}$ with a campaniform sensillum; K. bifurcated seta on tibia; L. satellite setae around antennal seta; M. Johnson's organ; N. short bluntended seta; O. minute setae on the intersegmental membrane between antennal segments IV and V. See 'Materials, methods and terminology' section for explanation of other abbreviations. 
Unmounted material. Third-instar female enclosed in hard, resinous, ovoid test (Fig. 1D, E), about 9-11 mm long and 7.5-8.5 $\mathrm{mm}$ wide, with orifice about $2 \mathrm{~mm}$ in diameter positioned at end opposite from attachment to stem; test yellow-orange (Argentine specimens) to red-brown (syntypes in USNM), but light yellow to brown according to Hempel (1932); external surface roughened by small bumps, but internal surface smooth and covered by a coat of powdery white wax.

Mounted specimens ( $\mathrm{n}=9)$. Body 3.5-7.0 mm long, 2.5-6.0 mm wide, with derm membranous except posterior end with a large, circular, strongly sclerotised anal disc. Antenna short (Fig. 16B), conical, 8 or 9 segmented, 290-390 $\mu \mathrm{m}$ long; scape 140-180 $\mu \mathrm{m}$ wide at base, segments tapering progressively to $60-80 \mu \mathrm{m}$ wide at base of apical segment; each segment with numerous short setae 10-30 $\mu \mathrm{m}$ long, and each segment except scape and apical segment with 1-3 fleshy setae, each 35-45 $\mu \mathrm{m}$ long; apical segment (Fig. 16B) with about 2 flagellate setae 40-55 $\mu \mathrm{m}$ long, and about 15-20 fleshy setae of 2 sizes: 5 or 6 thick fleshy setae, each $28-40 \mu \mathrm{m}$ long, and 10-15 slender fleshy setae, each 38-45 $\mu \mathrm{m}$ long. Eyespot 50-60 $\mu \mathrm{m}$ wide, situated posterolateral to base of antenna. Mouthparts well developed with labium 370-400 $\mu \mathrm{m}$ long, 3 segmented, but basal segment very narrow; apical segment with 10-12 setae, each 25-37 $\mu \mathrm{m}$ long, plus apex with 8 setae, each 40-50 $\mu \mathrm{m}$ long. Legs short (Fig. 16O), conical and strongly modified, with each segment present but considerably reduced. Metathoracic leg 390-430 $\mu \mathrm{m}$ long: coxa 80-110 $\mu \mathrm{m}$ long, 150-310 $\mu \mathrm{m}$ wide, with setae, each 10-25 $\mu \mathrm{m}$ long; trochanter + femur about 135-140 $\mu \mathrm{m}$ long; trochanter with a long trochanteral seta, 130-210 $\mu \mathrm{m}$ long, and 2 campaniform sensilla on each face; tibia about $60 \mu \mathrm{m}$ long, $105 \mu \mathrm{m}$ wide, tarsus 70-80 $\mu \mathrm{m}$ long, 100-105 $\mu \mathrm{m}$ wide, apex of tarsus bearing a short stout claw, 20-25 $\mu \mathrm{m}$ wide at its base, 25-30 $\mu \mathrm{m}$ long, with a pair of setose digitules, each 20-25 $\mu \mathrm{m}$ long; leg setae (except on coxa) mostly 12-20 $\mu \mathrm{m}$ long, a few slightly longer. Thoracic spiracles (Fig. 16P) each with peritreme $85-90 \mu \mathrm{m}$ wide, an apodeme $80-120 \mu \mathrm{m}$ long and 55-80 perispiracular multilocular pores. Abdominal spiracles (Fig. 16F) numbering 7 pairs; each atrium divided into 2 parts: a membranous outer atrium containing multilocular pores with a trilocular or quadrilocular centre and a sclerotised inner atrium, followed by a dense filamentous structure connected to a sclerotised short tube to which tracheae attached; each of anterior 5 pairs of spiracles with inner atrium $50-70 \mu \mathrm{m}$ wide and outer atrium with $20-80$ pores $(12-30$ pores in females from Argentina), with inner atrium reducing to $40-45 \mu \mathrm{m}$ wide in sixth pair and only $30-40 \mu \mathrm{m}$ wide in posteriormost spiracle located in sclerotised area of anal disc, and last 2 pairs of spiracles with many fewer pores in outer atria. Posterior end of abdomen with a large sclerotised circular area forming an anal disc up to $2.1 \mathrm{~mm}$ in diameter, with a strongly sclerotised central area about $1.3-1.4 \mathrm{~mm}$ in diameter, colour varying from dark brown in centre to light brown at periphery. Anal opening in the centre of anal disc, 100-120 $\mu \mathrm{m}$ in diameter; surrounded by a ring of elongate wax pores (Fig. 16G). Anal disc also bearing: (i) simple pores each with very wide rim (Fig. 16I); (ii) elongate tubular pores, each 23-25 wide, 36-40 $\mu \mathrm{m}$ long (Fig. 16H); (iii) small, stout, thick spiniform setae, each 15-22 $\mu \mathrm{m}$ long, with a short but well-sclerotised collar (Fig. 16J), and (iv) raised pores (Fig. 16K), each with a trilocular centre and 8 or 9 elongate outer loculi, located at centre of a raised, circular sclerotised derm, varying from $35-70 \mu \mathrm{m}$ in diameter.

Dorsum. Multilocular pores (Figs 16A, E), each 10-11 $\mu \mathrm{m}$ in diameter, mostly with a trilocular centre (rarely an oval bilocular or quadrilocular centre) and 8-12 outer loculi, scattered on head and thorax, and across abdominal segments. Flagellate setae (Fig. 16C), each mostly 10-15 $\mu \mathrm{m}$ long, sparsely distributed throughout on head and thorax and in a transverse line across each abdominal segment; hair-like setae longer, each up to $40 \mu \mathrm{m}$ long, rare on margin and sparse on abdomen. Cicatrices (Fig. 16M), each mostly 15-25 $\mu \mathrm{m}$ (a few up to $30 \mu \mathrm{m}$ ) in diameter, present on head and thorax, and in an irregular line across each abdominal segment. Disc-like tubercles (Fig. 16D), each 7-8 $\mu \mathrm{m}$ wide, with a sclerotised thick rim and a slightly domed centre; scattered on head and thorax, and present across each abdominal segment.

Venter. Multilocular pores, each $10-11 \mu \mathrm{m}$ in diameter, with a bilocular (Fig. 16A), trilocular (Fig. 16E) or quadrilocular (Figs 16L, Q) centre and 8-12 (mainly 10) outer loculi, scattered. Flagellate setae (Fig. 16C) scattered throughout; hair-like setae few, sparse throughout. Cicatrices (Fig. $16 \mathrm{M}$ ) in a transverse line on each abdominal segment, and scattered on head and thorax but absent medially on mid-thorax. Disc-like tubercles (Fig. $16 \mathrm{~N})$, similar to those on dorsum, scattered across each abdominal segment.

Second-instar nymph (Fig. 17). Note. Description is based only on specimens from Argentina and thus may not represent the full range of morphological variation. We also do not know whether the specimens are male or female.

Material examined. ARGENTINA: Provincia de Salta, Ruta 68, Quebrada del Rio de las Conchas, roadside, 
$26^{\circ} 03^{\prime} \mathrm{S}, 65^{\circ} 53^{\prime} \mathrm{W}$, ex test on stem of Parkinsonia praecox (Fabaceae), 20.x.2011, T. Kondo, 7 second-instar nymphs, each on a separate slide prepared by P.J. Gullan 2012 (5 IMLA, 2 USNM); Provincia de Tucumán, Valle Calchaquí, off Ruta $40,26^{\circ} 38^{\prime} \mathrm{S}, 66^{\circ} 02^{\prime} \mathrm{W}, 1850 \mathrm{~m}$, ex dry test on twig of P. praecox, 22.ii.2010, P.J. Gullan, 1 pharate second-instar nymph with its first-instar cuticle (USNM).

Mounted specimens ( $\mathrm{n}=8)$. Derm membranous, body ovoid or pyriform 1.8-4.2 mm long, 1.2-3.4 mm wide. Antenna 5-7 (mostly 6) segmented, 150-240 $\mu \mathrm{m}$ long; each segment very short; with 3 or 4 setae, each about 15 $\mu \mathrm{m}$ long, and with 1 or 2 thick fleshy setae, each about $30 \mu \mathrm{m}$ long; scape 80-120 $\mu \mathrm{m}$ wide, segments becoming progressively narrower to 45-70 $\mu \mathrm{m}$ to apical segment; apical segment (Fig. 17O) with 6 fleshy setae, each 25-35 $\mu \mathrm{m}$ long, plus 8 slender fleshy setae and 2 long hair-like setae of similar length, plus 4 short setae, each 12-15 $\mu \mathrm{m}$ long. Eyespot situated lateral to base of antennal scape. Mouthparts well developed; clypeolabral shield 500-520 $\mu \mathrm{m}$ long, labium 290-310 $\mu \mathrm{m}$ long, apex with about 10 setae. Legs (Fig. 17Q) present but considerably reduced, total length of each 180-280 $\mu \mathrm{m}$; coxa $60 \mu \mathrm{m}$ long, 90-130 $\mu \mathrm{m}$ wide with 4 or 5 setae, each $20-25 \mu \mathrm{m}$ long; segments becoming progressively smaller; each segment with short setae, 12-16 $\mu \mathrm{m}$ long; trochanter with a long seta, 96-110 $\mu \mathrm{m}$ long, and 2 oval campaniform sensilla on each side (Fig. 17Q); claw short but strong, about 10-20 $\mu \mathrm{m}$ long, with a pair of setose tarsal digitules shorter than claw. Thoracic spiracles (Fig. 17N) each with peritreme 50-70 $\mu \mathrm{m}$ wide, a strong apodeme 100-130 $\mu \mathrm{m}$ long, and about 25-30 perispiracular multilocular pores.

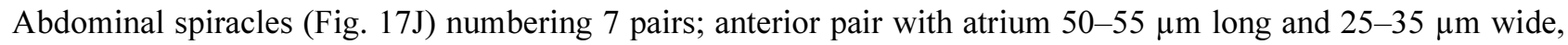
with about 6 or 7 atrial multilocular pores; successive atria reducing in size posteriorly to about $12 \mu \mathrm{m}$ wide with fewer atrial pores; seventh pair of spiracles without pores. Posterior end of body with a large circular, strongly sclerotised anal disc (Fig. 17P), 460-1100 $\mu \mathrm{m}$ in diameter. Anal disc bearing numerous raised multilocular pores, each with a trilocular centre and wide rim, and various short hair-like setae; anal tube opening in centre of disc. Anal tube 320-460 $\mu \mathrm{m}$ long, 55-90 $\mu \mathrm{m}$ wide, internal end with about 3 circles of polygonal wax pores, distally anal opening with a ring made of 25-43 elongated, sclerotised wax pores. Spinules present ventrally on medial and submedial areas of thorax and abdomen. Transverse apodemes on intersegmental lines of abdomen all well developed.

Dorsum. Pores on head and thorax slightly smaller than ventral pores. Multilocular pores circular, each usually $9-10 \mu \mathrm{m}$ in diameter, mostly with a trilocular centre and 7-9 outer loculi (Figs 17D, H), but occasionally with an oval bilocular or quadrilocular centre (Figs 17C, K), scattered on head and thorax, and with about 8-12 pores scattered across each abdominal segment. Dorsal setae few: short flagellate setae (Fig. 17E), each about 10-12 $\mu \mathrm{m}$ long, sparsely scattered on head and thorax and across abdominal segments; longer flagellate setae (Fig. 17F), each 20-25 $\mu \mathrm{m}$ long, scattered throughout. Margin with short, stout, curved hair-like setae (Fig. 17G), each 10-12 $\mu \mathrm{m}$ long. Stout conical seta very rare (Fig. 17B). Cicatrices (Fig. 17A), each mostly 15-25 $\mu \mathrm{m}$ (range 10-37 $\mu \mathrm{m})$ in diameter, in groups or scattered on head and thorax, and across each abdominal segment. Disc-like tubercles (Fig. 17I), each 7-8 $\mu \mathrm{m}$ in diameter with a sclerotised thick rim and a slightly domed centre; scattered on head, thorax and present in a transverse row on each abdominal segment.

Venter. Multilocular pores (Fig. 17H) more numerous than on dorsum, each usually 10-11 $\mu \mathrm{m}$ in diameter, mostly with a trilocular centre and 7-9 outer loculi similar to those on dorsum; randomly distributed on head and thorax, and in an irregular transverse line across each abdominal segment; with 26-45 pores on each abdominal segment. Multilocular pores with an oval or quadrilocular centre and 8-10 outer loculi (Fig. 17C), sparsely distributed. Setae few, most common type short (Fig. 17E), about 10-12 $\mu \mathrm{m}$ long, plus a few very short setae (each 5-8 $\mu \mathrm{m}$ ), distributed on body. Robust hair-like setae (Fig. 17B), each about 5-12 $\mu \mathrm{m}$ long with a well sclerotised base, mostly found on margin but also randomly distributed on head, thorax and abdomen. Flagellate setae (Fig. 17F), each about $20 \mu \mathrm{m}$ long, random throughout on head and thorax, and scattered across each abdominal segment; and curved hair-like setae (Fig. 17G) present on margin and submargin. Hairs sparsely scattered (Fig. 17L). Longest hair-like setae, each $40-110 \mu \mathrm{m}$, present on medial and submedial areas of head and thorax (Fig. 17M). Cicatrices (Fig. 15A), each mostly 15-25 $\mu \mathrm{m}$ (range 15-37 $\mu \mathrm{m}$ ) in diameter, distributed as follows: in a cluster on head and on each side of prothorax, a few cicatrices also often present between metathoracic legs, and scattered in irregular an transverse line of up to 10-18 across on each abdominal segment. Disc-like tubercles (Fig. 17I), similar to those on dorsum, each 7-8 $\mu \mathrm{m}$ in diameter, scattered on head, thorax and all abdominal segments.

First-instar nymph (Fig. 18). Type material examined. BRAZIL: State of São Paulo, Pirapitinguy, on angico do campo, Piptadenia falcata, 6.iii.1931, Adolph Hempel coll., syntypes: 5 first-instar nymphs on 1 slide (USNM). We also examined several photographs of morphological details made from 2 slides with 6 and 14 
syntype first-instar nymphs, labelled "Instituto Biológico / Neocoelostoma / xerophila Hemp. / sp. n. Type. / Coll. A. Hempel / R. 6. III: 31 [or just '6']', from IBSP, São Paulo, Brazil, made available by Dr A.L.B.G. Peronti of Universidade Federal de São Carlos, Brazil.

Other material examined. ARGENTINA: Provincia de Tucumán, Valle Calchaquí, Ruta 40, near Ruinas de los Quilmes, $26^{\circ} 28^{\prime} \mathrm{S}, 66^{\circ} 02^{\prime} \mathrm{W}$, c. $1850 \mathrm{~m}$, ex dry test on twig of Parkinsonia praecox (Fabaceae), 19.x.2011, P.J. Gullan \& T. Kondo coll., 15 nymphs on 5 slides prepared by P. J. Gullan 2012 (4 IMLA, 1 USNM); locality as above, 22.ii.2010, P.J. Gullan, 1 nymph (IMLA). URUGUAY: Montevideo, on Parkinsonia aculeata or Acacia sp., Dec. 1943, H.L. Parker, So. Amer. Par. Lab, 865, 1 slide with 8 first-instar nymphs (USNM); Montevideo, on $P$. aculeata, 31 Oct. 1940, H.L. Parker, No. 114-A and 41-2805, 20 nymphs on 4 slides (USNM).

Note: The figure is based on the Brazilian nymphs only.

Mounted specimens ( $\mathrm{n}=13$ ). Body elongate, $1200-1350 \mu \mathrm{m}$ long, 550-750 $\mu \mathrm{m}$ wide and, according to Hempel (1932), brown in colour. Antenna 6 segmented, 400-420 $\mu \mathrm{m}$ long; a campaniform sensillum on membranous area at apex of pedicel; apical segment (Fig. 18B) longest, 100-140 $\mu \mathrm{m}$, with 6 thick fleshy setae, each 35-45 $\mu \mathrm{m}$ long, plus up to 14 hair-like setae, each 35-70 $\mu \mathrm{m}$ long. Eyespot almost as large as first antennal segment, located near antennal base. Clypeolabral shield well developed; labium 3 segmented, elongate, conical, apex with 4 pairs of acute setae, each $45-55 \mu \mathrm{m}$ long; stylets very long, forming 3 or more loops inside body. Legs well developed. Metathoracic leg about $715 \mu \mathrm{m}$ long: coxa 50-65 $\mu \mathrm{m}$ long; trochanter + femur 230-250 $\mu \mathrm{m}$ long; trochanter with a long trochanteral seta, 100-130 $\mu \mathrm{m}$, and 2 campaniform sensilla on each side; femur dorsally with setae 20-32 $\mu \mathrm{m}$ long, ventrally 10-20 $\mu \mathrm{m}$ long; tibia 235-245 $\mu \mathrm{m}$ long, with setae 30-40 $\mu \mathrm{m}$ long; tarsus 170-180 $\mu \mathrm{m}$ long, with setae 20-45 $\mu \mathrm{m}$ long, tarsal digitules absent; claw (Fig. 18M) 30-40 $\mu \mathrm{m}$ long, with 1 pair of setose digitules, each 20-22 $\mu \mathrm{m}$ long, and a denticle near apex. Thoracic spiracles (Fig. 18N) each with peritreme $20-25 \mu \mathrm{m}$ wide, an apodeme and a small group of 2 or 3 perispiracular multilocular pores; each atrium 30-35 $\mu \mathrm{m}$ wide. Abdominal spiracles (Fig. 18F) numbering 7 pairs, each spiracle 18-24 $\mu \mathrm{m}$ long, $10-13 \mu \mathrm{m}$ wide at widest part, becoming progressively smaller posteriorly to 7-12 $\mu \mathrm{m}$ long and 5-6 $\mu \mathrm{m}$ wide; each atrium with conspicuous transverse corrugations; without atrial and perispiracular pores. Spinules medially on thorax, but densest on medial to submedial areas of abdomen. Posterior end with a sclerotised area (Fig. 18J) about $420 \mu \mathrm{m}$ wide with anal opening, 32-40 $\mu \mathrm{m}$ in diameter, at centre; a large stronger sclerotised ring of derm surrounding anal opening bearing a line of about 14 multilocular pores, each mostly with a trilocular centre; plus about 16 setae, each 30-35 $\mu \mathrm{m}$ long, present outside around anal opening. Anal tube about $345 \mu \mathrm{m}$ long, $48 \mu \mathrm{m}$ wide, inner extremity sclerotised with 2 rings of elongated wax pores.

Dorsum. Multilocular pores (Figs 18A, E), each 7.5-8.0 $\mu \mathrm{m}$ in diameter with a trilocular, quadrilocular, or quinquelocular centre and with about 8-10 (mainly 9) outer loculi, scattered throughout. A second kind of multilocular pore, each about $7.5 \mu \mathrm{m}$ wide with a quadrate centre and 4 outer elongated loculi (Fig. 18G), most common on abdomen. Other multilocular pores, each with 2 kinds of quadrate centre (Figs 18H, I), present on posterior end of abdomen. Setae of 2 types: (i) flagellate setae (Fig. $18 \mathrm{D}$ ), each 12-30 $\mu \mathrm{m}$ long, randomly distributed on head and thorax, and in an irregular transverse line on each abdominal segment, with up to 18 setae per segment; and (ii) hair-like setae (Fig. 18C), each 30-65 $\mu \mathrm{m}$ long, scattered throughout, longest on medial area. Cicatrices absent. Disc-like tubercles (Fig. 18C1), each 7-8 $\mu \mathrm{m}$ in diameter, sparsely scattered on head and thorax, and present across each abdominal segment.

Venter. Multilocular pores (Figs 18A, E), each 7.5-8.0 in diameter with a trilocular or quadrilocular centre and with mainly 9 outer loculi, in transverse lines on body. Hair-like setae, each 140-150 $\mu \mathrm{m}$ long, 2 on each side of median part of head; other hair-like setae (Fig. 18C), each 55-65 $\mu \mathrm{m}$ long, in 2 longitudinal medial lines on thorax and abdomen and shorter setae in a transverse row on each abdominal segment. Flagellate setae (Fig. 18D), mostly each 20-30 $\mu \mathrm{m}$ long, scattered throughout and randomly mixed with minute setae, latter about $10 \mu \mathrm{m}$ long, across each abdominal segment. Posterior end of abdomen with 2 pairs of long caudal setae, each 500-600 $\mu \mathrm{m}$, (Fig. 18O): also with 2 pairs of shorter setae, each 35-45 $\mu \mathrm{m}$, between caudal setae. Cicatrices (Fig. 18K) round, each 25-30 $\mu \mathrm{m}$ in diameter, with 3 in a transverse line on posterior medial abdomen. Disc-like tubercles absent.

Adult male (Fig. 19). Material examined. ARGENTINA: Provincia de Tucumán, Valle Calchaquí, Ruta 40, near Ruinas de los Quilmes, $26^{\circ} 28^{\prime} \mathrm{S}, 66^{\circ} 02^{\prime} \mathrm{W}$, c. $1850 \mathrm{~m}$, on stems of Parkinsonia praecox (Fabaceae), 19.x.2011, Gullan \& Kondo coll., 2 adult males (one very damaged) on 2 slides prepared by PJG (1 IMLA, 1 USNM). URUGUAY: Montevideo, on Acacia farnesiana or Parkinsonia aculeata, 1-17.xi.1943, Parker \& Berry coll., S. Amer. Parasite Lab. $N^{\circ} .865,5$ of 10 adult males on 10 slides prepared from dry material by PJG in 2009 (USNM); 
Montevideo, on Parkinsonia aculeata, H.L. Parker coll., 2 adult males on 2 slides prepared by Claude Richard, 1975 (MNHN), from gift of H.L. Parker in 1943.

Mounted specimens $(n=9)$. Extremely large, $6.4-7.0 \mathrm{~mm}$ long (with caudal filaments) and $1.57-1.80 \mathrm{~mm}$ wide across prealare. Almost all of body with numerous setae and pores: setae of 2 types (Fig. 19C): (i) hair-like setae (hs) of very variable length, each 35-125 $\mu \mathrm{m}$ long, with rather shallow basal sockets, and (ii) hairs (hrs), much shorter than hs and without a basal socket, each about 16-30 $\mu \mathrm{m}$ long; both types present more or less throughout. Pores of 3 types: (i) convex loculate pores (lp) (Figs 19B, D, G) (each 8-10 $\mu$ m wide, mainly with 3 or 4 loculi), abundant almost throughout on both surfaces wherever setae present, (ii) convex pores (cp) (Fig. 19A) restricted to lateral and ventral surfaces of head, each 6-8 $\mu \mathrm{m}$ wide, perhaps with micropores, and (iii) small sclerotised pores (msp), each 2-3 $\mu \mathrm{m}$ wide, sclerotised and with apex flush with derm surface, present on ventral surface of head and on lateral areas of prothorax but not detected elsewhere. Antenna long, without nodes, setae randomly distributed, of 3 types (i) largest (probably fleshy setae (fs)) each with 0-2 satellite setae (sats) (Fig. 19L), (ii) much shorter hs, and (iii) most segments with short blunt-ended setae (Fig. 19N), perhaps very small antennal bristles (ab). Sclerotised areas without nodulations. Scutum with a membranous area medially. Legs well developed and very setose, many setae spur-like and some strongly bifurcate (bs) (Fig. 19K), particularly on posterior surface of profemora and distally on all tibia; each tarsus 2 segmented; claw without a denticle; claw digitules setose. Abdominal segment I not visible ventrally; abdomen with 3 pairs of long lateral lobes or caudal extensions (ce), those on segment VIII longest, becoming gradually shorter on segments VII \& VI; absent on segments V-I; abdomen without tubular ducts (tdc). Penial sheath and anal structures all ventral. Abdominal spiracles present (Fig. 19F).

Head. Triangular in dorsal view, length 500-630 $\mu \mathrm{m}$, width across compound eyes 850-890 $\mu \mathrm{m}$. Dorsally with a well-developed postoccipital suture (pos) extending across posterior part of epicranium (dmep), and with a narrow postocciput (poc) posteriorly. Dorsomedial part of epicranium (dmep) apparently entirely membranous; midcranial ridge (mcr) absent. Dorsal surface covered in numerous hs, a few hrs and several lp. Laterally with a pair of compound eyes (cde), each about 380-385 $\mu \mathrm{m}$ long, with 130+ ommatidia. Each compound eye (cde) with a narrow, sclerotised ocular sclerite (ocs) along dorsal margins, each with a single ocellus (o) dorsally, close to postoccipital suture, width about $60 \mu \mathrm{m}$; each eye with a longitudinal postocular ridge (pocr) close to dorsal margin, extending from near each ocellus around dorsal margin of ocular sclerite (ocs) to posterior margin of each eye; ventral projection (p) probably absent. Preocular ridge (procr) absent dorsally. Ventrally with a strongly sclerotised series of ridges forming a five-armed cross, composed of: (i) midcranial ridge (vmcr) anteriorly, extending posteriorly from between antennae on anterior margin of head to (ii) a pair of preocular ridges (procr), which originate from between each antenna and compound eye laterally, and (iii) a pair of posterior preoral ridges (pror) extending laterally to posterior margin of each cde. Ventral part of epicranium membranous apart from some light sclerotisation medially between vmcr and procr and between procr and pror. Setal distribution as follows: anteriorly between mid-cranial ridges (vmcr) and antennae with many hs, plus a few hs; also several lp, cp and $\mathrm{msp}$; lateral area between preocular and preoral ridges without pores; area posterior to preoral ridges with a group of hs, hrs and lp, in a semi-circle around mouth (m). Cranial apophysis small, represented by a shallow indentation immediately posterior to preocular ridges medially. No structures representing tentorial arms, tentorial bridge or tendon-like apodeme detected. Ventral sclerites present just posterior to each compound eye. Antenna: 10segmented; length about $4 \mathrm{~mm}$ (ratio of total-body length to antennal length 1:0.57). Setae on most segments of 3 types, all randomly arranged (not in whorls): (i) very long setae, most 160-225 $\mu \mathrm{m}$ long, probably all fleshy setae (fs), many with 0-2 satellite setae (sats) (Fig. 19L); (ii) much shorter hair-like setae, each about 30-35 $\mu \mathrm{m}$ long, and (iii) short setae with a blunt apex (Fig. 19N), which might be short antennal bristles (ab), each about 16-20 $\mu \mathrm{m}$ long. In addition, there are minute setae on intersegmental membranes (Fig. 19O) between segments IV \& V and VI \& VIII; bifurcated setae absent; what might be small sclerotised pores also present on segments IV-VI. Scape (scp) 177-205 $\mu \mathrm{m}$ long, 170-210 $\mu \mathrm{m}$ wide, sclerotised, with a strong basal articular process (bap) extending posteriorly from each scape laterally; with 40-50 short setae, each about 62-112 $\mu \mathrm{m}$ long. Pedicel (pdc) $225 \mu \mathrm{m}$ long, 135-160 $\mu \mathrm{m}$ wide; with many setae (as above) plus a campaniform sensillum (camp) on distal dorsal margin. Segments III-IX of flagellum each with parallel margins (i.e. without nodes); basal segments broadest (about 120 $\mu \mathrm{m}$ wide), segments gradually narrowing towards apex; each with about 50 setae including all 3 types. Segment $X$ elongate, quite narrow, with a more diffuse group of long setae, otherwise with shorter setae; 1 basiconic sensilla (bass) present; capitate setae (caps) absent and antennal bristles undifferentiated (unless short blunt-ended setae are 

265-330.

Thorax. Prothorax: head broadly attached to prothorax, with no cervical groove. Dorsally without any pronotal structures, but with a pair of diagonal post-tergites (pt) (each about 410-469 $\mu \mathrm{m}$ long) which broaden slightly at each end. Laterally with a pair of strong cervical sclerites (cv) which articulate anteriorly with posterior end of ocular sclerite (ocs) and preoral ridge (pror); cv with a proepimeron $\left(\mathrm{epm}_{1}\right)$. Pleural ridge $\left(\mathrm{plr}_{1}\right)$ short, extending dorsally from articulation with coxa; pleural apophysis $\left(\mathrm{pl}_{1} \mathrm{a}\right)$ distinct. Ventrally: prosternum $\left(\mathrm{stn}_{1}\right)$ with a well-sclerotised median ridge, $570 \mu \mathrm{m}$ long, which broadens slightly posteriorly with an obvious sternal apophysis $\left(\operatorname{stn}_{1} a\right)$ at posterior end. Most of membranous areas covered in short setae and $1 \mathrm{p}$, as follows: with a broad group of median pronotal setae (mpns) and pores extending between post-tergites over anterior end of prescutum; with a large group of lateral pronotal setae (lpns) and pores anteriorly on each side, plus a large group of propleural setae anteriorly and posteriorly on each side; anteprosternal and antemesospiracular setae and pores rather obscured by legs but present; with a sparse group of prosternal setae and pores on each side of prosternum. Mesothorax: dorsally: prescutum (prsc) large and approximately oval to triangular (length 570-640 $\mu \mathrm{m}$, width medially 615-745 $\mu \mathrm{m}$ ); mesoprephragma ( $\mathrm{phr}_{2}$ ) large; prescutal ridges (pscr) few, along margin of prescutal suture (pscs) but absent medially. Scutum (sct) with a moderate sized, narrowly oval, membranous area medially just posterior to prescutum, length 105-165 $\mu \mathrm{m}$, width 385-580 $\mu \mathrm{m}$, with about 40 hs scutal setae (scts) but no lp; sclerotised part of scutum with a group of hs (some rather small) and $\mathrm{lp}$ on either side of scutellum, plus a few hs lateral to membranous area. Scutellum (scl) triangular; scutoscutellar sutures (scuts) extending from membranous area of scutum anteriorly postero-laterally to postalare (pa); each outer angle with an approximately oval membranous area; with 6-8 hs scutellar setae (scls) on sclerotised area; without pores. Laterally: prealare (pra) elongate, triangular plate absent. Tegula (teg) well developed, with a large group of hs tegular setae (tegs) and lp. Mesopleural ridge $\left(\mathrm{plr}_{2}\right)$ well developed, with a deep pleural apophysis $\left(\mathrm{pla}_{2}\right)$. Mesepisternum $\left(\mathrm{eps}_{2}\right)$ not nodulated; membranous area posteriorly with a few hs and lp. Ventrally: basisternum $\left(\operatorname{stn}_{2}\right)$ large, length 535-750 $\mu \mathrm{m}$, width $975-1050 \mu \mathrm{m}$; with a distinct, complete, sclerotised median ridge (mdr); bounded anteriorly by a marginal ridge $(\mathrm{mr})$ and posteriorly by well-developed precoxal ridges $\left(\mathrm{pcr}_{2}\right)$; with a line of basisternal setae $\left(\operatorname{stn}_{2} \mathrm{~s}\right)$ along mdr; furca (f) moderately narrow posteriorly, only slightly waisted, with quite short arms, which diverge strongly; lateropleurite (lpl) apparently absent; subepisternal ridge (ser) short. With a dense band of postmesospiracular setae $\left(\mathrm{pm}_{2} \mathrm{~s}\right)$ and lp posterior to each mesothoracic spiracle $\left(\mathrm{sp}_{2}\right)$ but these not extending along anterior margin of basisternum. Mesothoracic spiracles $\left(\mathrm{sp}_{2}\right)$ large, width of each peritreme about $145 \mu \mathrm{m}$. Wing sclerites: showing nothing distinctive. Metathorax: dorsally: metapostnotum $\left(\mathrm{pn}_{3}\right)$ present as a pair of sclerites that appear to fuse with tergite on abdominal segment I; with a large group of metatergal setae (mts) extending across segment. Laterally: dorsospiracular setae (dss) and lp frequent. Suspensorial sclerites (ss) present. Pleural ridge ( $\mathrm{plr}_{3}$ ) well developed; precoxal ridge $\left(\mathrm{pcr}_{3}\right)$ well developed and extending about $350 \mu \mathrm{m}$ medio-ventrally; with a moderately deep pleural apophysis $\left(\mathrm{pla}_{3}\right)$. Metepisternum $\left(\mathrm{eps}_{3}\right)$ not sclerotised; metepimeron $\left(\mathrm{epm}_{3}\right)$ represented by a strong sclerotisation extending dorso-posteriorly around metacoxae. Ventrally: metasternum $\left(\operatorname{stn}_{3}\right)$ un- or only lightly sclerotised but with large lateral apophyses $\left(\operatorname{stn}_{3} \mathrm{a}\right)$. Postmesoprecoxal ridge setae and anterior metasternal setae abundant plus a few lp, extending along posterior margin of basisternum, and across segment anterior to metasternum; posterior metasternal setae (pmss) also abundant plus frequent lp, in a broad group between ventral sections of pleural ridge and including postmetaspiracular setae $\left(\mathrm{eps}_{3}\right)$. Posterior spiracles $\left(\mathrm{sp}_{3}\right)$ large: width of each peritreme about $160-185 \mu \mathrm{m}$.

Wings. Well developed, each 4.3-5.0 $\mathrm{mm}$ long, about $2 \mathrm{~mm}$ wide (ratio of wing length to total body length 1:1.4). Subcostal thickening (sclt) well developed; wing anterior to sclt well sclerotised; rest of wing membranous but with reticulations formed from micro-ridges, each reticulation itself with minute reticulations; with a line of many circular sensoria (sens) and fine setae (als) extending distally from where radius (rad) and medial (med) veins meet; radius and medial veins extending close to apex of wings; alar fold present. Without setae near wing base. Alar lobe (al) well developed and sclerotised. Hamulohalteres (h) (Fig. 19E) probably mainly sclerotised and quite broad, narrowing proximally; length about $570 \mu \mathrm{m}$, width about $255 \mu \mathrm{m}$; with $6-8$ hamuli (ham), each hooked and about $85-115 \mu \mathrm{m}$ long. Wing sclerites showing nothing distinctive.

Legs. Subequal in length. Coxae (cx) lengths: I 475; II 400; III 425-500 $\mu$ m; each with many setae. Trochanter (tr) + femur (fm) lengths: I 900; II 750-950; III 725-925 $\mu \mathrm{m}$; trochanter with several shortish setae +1 long 
flagellate seta (length about $350 \mu \mathrm{m}$ ); trochanter (tr) with a curved line of probably 4 round campaniform sensilla (camp) on each side; femur (fm) with many setae, most shortish (70-105 $\mu \mathrm{m}$ long), but some along ventral and dorsal surfaces up to $190 \mu \mathrm{m}$; posterior margin of profemur with many bifurcate setae (bs) (these absent from femora of other legs). Tibia (ti) lengths: I 1050; II 870-1000; III 875-1050; distal 2/3rds with bifurcated setae (bs) laterally and ventrally (but quite difficult to see), these replaced by long flagellate setae dorsally; with many tibial spurs (tibs) distally, longest about $60 \mu \mathrm{m}$ long. Tarsi (ta) 2 segmented (Fig. 19J), proximal segment (ta ${ }_{1}$ ) very short and triangular; length of $\mathrm{ta}_{1}+\mathrm{ta}_{2}$ : I 440; II 375-440; III 375-450; with an indistinct tarsal campaniform sensillum (camp); with bifurcated spur-like setae (bs) along ventral margin and laterally, lateral setae all short but some dorsal setae slightly longer; tarsal spurs (tabs) on distal end not differentiated; tarsal digitules (tdgt) probably represented by 2 fine setae on dorsal margin near claw. Claws (c) elongate, without a denticle (cd); claw III about 135-160 $\mu \mathrm{m}$ long, with 2 digitules (cdgt), each setose and shorter than claw.

Abdomen. Caudal extensions (ce) absent on segments I-V, short (about $1250 \mu \mathrm{m}$ long) on VI, longer on VII and VIII (about $2 \mathrm{~mm}$ and $2.25 \mathrm{~mm}$ respectively); each extension with many hs setae (Fig. 19I) throughout, plus a few hs and lp, most abundant towards base. Small tergites (at) present mediolaterally on anterior borders of all segments; sternites (as) absent apart from margin between VII and VIII. Setae: hs and hrs more abundant on ventral surface; lp about as frequent as dorsal setae (ads) on dorsal surface, much less frequent than abdominal ventral setae (avs) on ventral surface. Other pore types not located. Pleural setae and pores apparently not divided into dorsal and ventral pleural groups but each group fairly clearly separated from dorsal and ventral abdominal setae; each group with numerous hs and a few lp; pleural setae not significantly longer than elsewhere, longest setae perhaps on caudal extensions. Abdominal spiracles (Fig. 19F) probably present on anterior margins of segments IV-VII, but perhaps also present as far forward as I; most heavily sclerotised posteriorly, hard to distinguish anteriorly although trachea present.

Genital segment. Anus (an) located between caudal extensions of segment VIII, consisting of a sclerotised ring (80-125 $\mu \mathrm{m}$ wide), without setae or pores, just anterior to dorsal margin of penial sheath and possibly connected to penial sheath ventrally by a sclerotised bar with a pair of finger-like processes extending posteriorly, each with many short setae. Penial sheath (ps) heavily sclerotised, positioned ventrally and immediately below anus; penial sheath $650-850 \mu \mathrm{m}$ long, 300-312 $\mu \mathrm{m}$ wide at broadest point, narrowing posteriorly to 2 short, blunt, parallel-sided finger-like processes (total width $186 \mu \mathrm{m}$ wide) that join dorsally; each process with many small sensoria apically and small setae more anteriorly. Aedeagus (aed) possibly mainly membranous, in a groove along venter of penial sheath, with a very long, strongly setiferous, eversible endophallus (eph) (Fig. 19H), normally retracted into body, length $1.8-2.0 \mathrm{~mm}$.

\section{Paracoelostoma Morrison}

Paracoelostoma Morrison, 1927: 102. Type species: Paracoelostoma peruviana Morrison, by monotypy and original designation.

The genus Paracoelostoma is monotypic, with the type species originally known as $P$. peruviana Morrison. This name was amended by D.J. Williams (2011) to P. peruvianum Morrison to agree with the neuter gender of the genus. Although the original description was very brief, Morrison (1928) provided a detailed redescription with illustrations of the adult and preadult females and the first-instar nymph.

Generic diagnosis. In this test-forming genus, each immature stage of development is enclosed within a thickly-walled test (Fig. 1F), in which the adult female remains and oviposits. The only known species is from Samán in the Piura region of coastal Peru on a plant belonging to the family Sapotaceae.

Adult female. Body ovoid to globular; derm membranous, except that surrounding anal opening that becomes sclerotised at maturity. Antenna much reduced. Mouthparts present; labium 3 segmented. Legs reduced, without distinct segments; claw curved with setose digitules. Thoracic spiracles large, each with a wide apodeme and peritreme with a cluster of perispiracular multilocular pores. Abdominal spiracles numbering 7 pairs, posteriormost pair smallest and close to anal opening; atrium of each spiracle with pores. Anal opening apical, surrounded by a wide circular cluster of dense setae; anal tube with a sclerotised ring at inner end and anal tube of preadult often retained. Multilocular pores with a bilocular or trilocular centre, present on dorsum and venter. Spines absent. Small stiff setae mixed with hairs scattered over body. Cicatrices and disc-like tubercles absent. 
Third-instar (preadult) female. Derm membranous except heavily sclerotised posteriorly in a large circular area bearing numerous pores, with anal opening at centre. Antenna 5 or 6 segmented. Mouthparts present; labium 3 segmented. Legs with segments reduced in size; claw curved with setose digitules. Thoracic spiracles each with a large apodeme and peritreme with a cluster perispiracular pores. Abdominal spiracles numbering 7 pairs, atria with pores; posterior spiracles localised within sclerotised area, close to anal opening. Several kinds of multilocular pores, each with a circular or triangular centre, scattered on dorsum and venter. Small setae, each with a stout socket, and short stiff hairs, scattered. Cicatrices numerous ventrally, variable in size, in transverse irregular, segmental rows on abdomen and submarginally on head and thorax. Also circular to oval cicatrix-like structures scattered on dorsum and venter. Disc-like tubercles absent.

First-instar nymph. Elongate, derm membranous apart from a heavily sclerotised plate surrounding anal opening posteriorly. Antenna 6 segmented, with segments stout; apical segment largest and swollen. Mouthparts well developed; labium long, conical, 3 segmented. Legs well developed; claw with a distinct denticle. Thoracic spiracles large, each with an apodeme and a group of perispiracular pores. Abdominal spiracles elongate, tubular, numbering 7 pairs; posterior pair much smaller and not enclosed within sclerotised anal area; each outer atrium with a single multilocular pore. Anal tube with 3 rings of polygonal wax glands at inner end; anal opening at centre of a wide, sclerotised plate bearing setae and pores; each pore on a raised, circular, sclerotised area of derm, with pores densely clustered. Multilocular pores with a circular, wide centre and about 10 outer loculi, present on most of body. Derm without spines but with small setae, each with a large, flat basal collar, also with a few stiff short hairs with a swollen base. Posterior end of abdomen with 2 pairs of long caudal setae, each more than $300 \mu \mathrm{m}$ long. Ventral cicatrices in one submedial longitudinal line on each side of abdomen, usually with 6 cicatrices in each line. Disc-like tubercles absent.

\section{Paracoelostoma peruvianum Morrison}

Paracoelostoma peruviana Morrison, 1927: 102-103; Morrison, 1928: 97-100.

Paracoelostoma peruvianum; Williams, 2011: 67. Justified emendation.

Morrison's type material was from two collections in Peru: (1) Despo Blado, near Samán, Piura, collected 29 April 1912, by E.W. Rust (included holotype) and (2) Samán, collected 21 May 1910 by C.H.T. Townsend. All types are in the USNM.

Type material examined. PERU: Holotype: adult female (the glass of the slide is engraved with the word 'holotype'); Despo Blado, near Samán, Piura, April 29, 1912, E.W. Rust coll. (USNM). Paratypes: 3 original slides each with one adult female and 1 original slide with a preadult female, all with the same data as holotype (USNM); 1 slide of adult female and its preadult exuviae, from remains of dry female ex test in box with label: "Paracoelostoma peruviana Morr. 16 / Despo Blado / Near Samán, Prov. of Piura, Peru. E.W. Rust Coll. Apr. 291912", slide prepared by P.J. Gullan 2010 (USNM); 2 slides, each with one female and its preadult exuviae, from remains of dry female ex test, plus 5 slides of first-instar nymphs (each slide 9-12 specimens) ex dry tests of 2 females, all from box with label: "Paracoelostoma peruviana Morr. On Zapote / Paratype / Samán, Peru (C.H.T. Townsend \#228), May 21, 1910”, slides prepared by P.J. Gullan 2010 (USNM).

Notes. There are other slides (original and prepared by PJG from dry type material) and dry material from these two collections in the USNM. The host plant was referred to as "zapote" on the labels of some of the USNM slides and dry material, and as "Achras sapota" in Morrison's (1928) description. This plant has many synonyms and is known now as Manilkara zapota (Sapotaceae) (The Plant List, 2010), commonly called sapote or sapodilla.

Adult female (Fig. 20). Mounted specimens ( $\mathrm{n}=4)$. Body oval to globular at maturity, 4.4-5.0 $\mu \mathrm{m}$ long, 3.2-3.6 $\mu \mathrm{m}$ wide (holotype $4.6 \mathrm{~mm}$, long, $3.4 \mathrm{~mm}$ wide). Derm membranous; dorsal posterior end of body with a dense group of setae surrounding anal opening, this small zone becoming slightly sclerotised at maturity (Fig. 20F). Antenna (Fig. 20A) 240-260 $\mu \mathrm{m}$ long, 5 or 6 segmented, each segment with short flagellate setae 20-30 $\mu \mathrm{m}$ long;

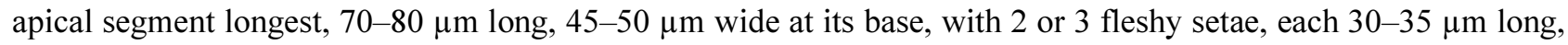
and 6-8 flagellate setae, each 25-65 $\mu \mathrm{m}$ long; 2 preapical segments each with 1 or 2 fleshy setae. Eyespot situated lateral to antennal scape. Mouthparts well developed; clypeolabral shield 285-300 $\mu \mathrm{m}$ long; labium conical, apparently 3 segmented, 140-150 $\mu \mathrm{m}$ long with basal segment quite narrow. Legs (Fig. 20I) short, total length of each $230-260 \mu \mathrm{m}$, segmentation not very distinct; trochanter with a long seta, 70-90 $\mu \mathrm{m}$ long, and 2 campaniform 
sensillum on each side; claw about $50 \mu \mathrm{m}$ long with a pair of setose digitules. Thoracic spiracles (Fig. 20H) each with peritreme 130-140 $\mu \mathrm{m}$ wide and with 8-12 perispiracular multilocular pores; each pore with an oval centre and with more than 14 outer loculi. Abdominal spiracles (Fig. 20G) numbering 7 pairs; each inner atrium sclerotised, 100-110 $\mu \mathrm{m}$ wide, its opening to outer atrium with a network of dense filaments, inner atrium opening into a narrower sclerotised tube connected to tracheae; each outer atrium membranous with 6-10 multilocular pores; spiracular atria becoming progressively smaller posteriorly (measured at base of inner atrium) from $80 \mu \mathrm{m}$ to $70 \mu \mathrm{m}$, with posteriormost pair only 50-55 $\mu \mathrm{m}$ wide and set close to anal opening. Anal tube (Fig. 20E) with a sclerotised inner end; anal opening dorsal, at centre of sclerotised zone. On mature specimens, intersegmental membranes of abdomen each with pronounced sclerotisations that project inwards as apodemes.

Dorsum. Multilocular pores of 2 kinds: (i) slightly elliptical pores, each about $10 \mu \mathrm{m}$ wide, with a bilocular centre and 14-16 outer loculi (Fig. 20B); and (ii) circular pores, each about $10 \mu \mathrm{m}$ wide with a triangular centre and 18-20 outer loculi (Fig. 20C); both distributed throughout dorsum and most abundant on abdomen. Short flagellate setae (Fig. 20D), each 12-16 $\mu \mathrm{m}$ long, scattered over body. Posteriorly with a large circular cluster of short flagellate setae (Fig. 20F), each 20-50 (mainly 30-35) $\mu \mathrm{m}$ long, located on an area approximately 800-900 $\mu \mathrm{m}$ wide, surrounding anal opening; this area becoming slightly sclerotised at maturity. Cicatrices and disc-like tubercles absent.

Venter. Multilocular pores (Figs 20B, C) similar to those on dorsum, most numerous across abdominal segments, very few on posterior thorax and near spiracles, and absent on head and anterior thorax. Short flagellate setae (Fig. 20D), each 14-22 $\mu \mathrm{m}$ long, scattered throughout on head and thorax, and in transverse rows across abdominal segments. Longer flagellate setae (Fig. 20F), each 50-60 $\mu \mathrm{m}$ long, in longitudinal medial line on abdomen. A pair of robust medial setae, each 150-160 $\mu \mathrm{m}$ long, present between clypeolabral shield and antennae. Cicatrices and disc-like tubercles absent.

Third-instar (preadult) female (Figs 1F, 21). Mounted specimens ( $\mathrm{n}=4)$. Body broadly oval, transforming to globular at maturity; 4.5-4.9 mm long, 3.3-4.1 mm wide. Derm membranous, with areolations over dorsum (detail of a small area in Fig. 21A). Dorsal posterior end of abdomen (Fig. 21J) with strongly sclerotised derm forming a circular plate around anal opening, about $1 \mathrm{~mm}$ in diameter. Antenna (Fig. 21B) 230-265 $\mu \mathrm{m}$ long, 5 or 6 segmented, all segments with short flagellate setae; segments narrowing considerably towards apex, scape $150 \mu \mathrm{m}$ wide, and apical segment 60-65 $\mu \mathrm{m}$ wide, 50-60 $\mu \mathrm{m}$ long, with 5 short setae and 5 or 6 fleshy setae; 2 preceding segments each with 2-4 fleshy setae. Eyespot situated lateral to antennal scape. Mouthparts well developed; clypeolabral shield about 435-445 $\mu \mathrm{m}$ long; labium conical, 3 segmented, about $310 \mathrm{~mm}$ long, apical segment with about 6-8 setae. Legs (Fig. 21M) short, each 150-160 $\mu \mathrm{m}$ long, segments broad, with few setae; trochanter shortest segment, with 2 campaniform sensilla on each side; claw curved, 20-24 $\mu \mathrm{m}$ long. Thoracic spiracles (Fig. 21O) each with a large apodeme and a peritreme about $85 \mu \mathrm{m}$ wide, and with numerous perispiracular multilocular pores; each pore with a bilocular centre and 13-14 outer loculi (Fig. 21N). Abdominal spiracles (Fig. 21F) numbering 7 pairs, each with peritreme $50-55 \mu \mathrm{m}$ wide; each sclerotised inner atrium with a network of filaments and opening into a sclerotised tube connected to tracheae; each outer atrium membranous with 10-16 pores; posteriormost pair of spiracles smallest, about $40 \mu \mathrm{m}$ in diameter, set in a sclerotised plate, close to anal opening. Posterior dorsal abdomen with a wide circular, strongly sclerotised plate, $850-1000 \mu \mathrm{m}$ in diameter, with anal opening at centre and bearing multilocular pores; each pore located on small membranous area, isolated as a small island by sclerotised derm (Fig. 21J); periphery of plate with raised simple pores (Fig. 21I) and with very few setae. Anal tube membranous, about $450 \mu \mathrm{m}$ long, inner end with wax pores. Intersegmental lines of abdomen which sclerotised patches appearing as membranous sac-like structures (Fig. 21G), each 120-200 $\mu \mathrm{m}$ long, 40-70 $\mu \mathrm{m}$ wide.

Dorsum. Multilocular pores of 2 kinds: (i) circular pores (Figs 21E, H), each 9-10 $\mu \mathrm{m}$ in diameter with a wide circular or triangular centre and 10-12 outer loculi; and (ii) slightly larger and oval pores (Fig. 21N), each about 11 $\mu \mathrm{m}$ wide with a bilocular centre and 16-20 outer loculi; both pore kinds sparsely scattered throughout. Small short stiff or slender flagellate setae (Fig. 21D), each 10-30 $\mu \mathrm{m}$ long, sparsely distributed throughout. Cicatrix-like structures (Fig. 21C), each 20-30 $\mu \mathrm{m}$ wide, composed of a circular to oval, flat membranous derm, with a rim and surrounded by areolated derm, distributed throughout.

Venter. Multilocular pores of 3 kinds: (i) circular pores (Fig. $21 \mathrm{H}$ ), each 10-11 $\mu \mathrm{m}$ wide with triangular centre and 12-14 outer loculi, sparsely scattered on head and thorax and in a transverse row on each abdominal segment; (ii) circular pores (Fig. 21E), each $10 \mu \mathrm{m}$ wide with circular centre and 12-14 outer loculi, sparsely scattered on 
head and thorax; and (iii) oval pores (Fig. $21 \mathrm{~N}$ ), each 10-11 $\mu \mathrm{m}$ wide with a bilocular centre and 12-14 outer loculi, clustered around each peritreme of thoracic spiracles, and sparsely distributed throughout on thorax. Small, short, slender flagellate setae (Fig. 21D), each 10-12 $\mu \mathrm{m}$ long, densely distributed throughout; longer flagellate setae, each 15-20 $\mu \mathrm{m}$ long, sparsely scattered. Hairs (Fig. $21 \mathrm{~K}$ ) sparsely present posteriorly on abdomen. Cicatrices (Fig. 21L) numerous, varying in size from 15-32 $\mu \mathrm{m}$ wide, present submarginally on head and thorax, and densely distributed in irregular segmental rows on abdomen. Cicatrix-like structures (Fig. 21C), similar to those on dorsum, each 20-30 $\mu \mathrm{m}$ wide, composed of a circular to oval, flat area of membranous derm, with a rim, surrounded by areolated derm, distributed throughout. Derm with spinules (Fig. 21P) present on medial to submedial area on abdomen.

First-instar nymph (Fig. 22). Mounted specimens ( $\mathrm{n}=10$ ). Body elongate, oval, 600-700 $\mu \mathrm{m}$ long, 330-345 $\mu \mathrm{m}$ wide. Derm membranous except posteriorly. Antenna 245-260 $\mu \mathrm{m}$ long, 6 segmented, each segment with setae 30-40 $\mu \mathrm{m}$ long; apical segment (Fig. 22A) longest, about $80 \mu \mathrm{m}$ long, with 4 or 5 fleshy setae, each 35-40 $\mu \mathrm{m}$ long, 3 longer non-fleshy setae, each $75 \mu \mathrm{m}$ long, and 6 or 7 non-fleshy setae, each 35-40 $\mu \mathrm{m}$ long; a campaniform sensillum present on membranous apex of pedicel. Eyespot situated lateral to antennal scape. Mouthparts well developed; clypeolabral shield 270-295 $\mu \mathrm{m}$ long; labium conical, apparently 3 segmented, about 140-160 $\mu \mathrm{m}$ long, apical segment with 8-10 sensory setae. Prothoracic leg shortest, about $450 \mu \mathrm{m}$ long; metathoracic leg about $490 \mu \mathrm{m}$ long, with trochanter + femur 160-172 $\mu \mathrm{m}$ long, trochanter with 2 campaniform sensilla on each side and a long trochanteral seta, $130 \mu \mathrm{m}$ long; tibia 95-120 $\mu \mathrm{m}$ long; tarsus 125-135 $\mu \mathrm{m}$ long, proximal part with a campaniform sensillum; claw (Fig. 22L) curved, 30-34 $\mu \mathrm{m}$ long, with a pair of setose digitules at base and a small denticle near apex. Thoracic spiracles (Fig. 22M) each with atrium 22-24 $\mu \mathrm{m}$ wide and peritreme $26-30 \mu \mathrm{m}$ wide and usually with 2 or 3 perispiracular multilocular pores; each pore with a bilocular centre and 10 outer loculi. Abdominal spiracles (Fig. 22E) small, numbering 7 pairs; each spiracle 19-22 $\mu \mathrm{m}$ long with peritreme 12-15 $\mu \mathrm{m}$ wide, with inner atrium sclerotised and wider than membranous outer atrium that bears one pore; posteriormost pair of spiracles smallest and sometimes included in sclerotised plate. Anal tube (Fig. 22F) membranous, 90-100 $\mu \mathrm{m}$ long, inner end with three rings of polygonal wax pores; anal opening dorsal, 32-36 $\mu \mathrm{m}$ wide. Posterior end of abdomen with a sclerotised plate (Fig. 22G), either triangular in shape or more or less circular, 170-210 $\mu \mathrm{m}$ at widest part, surrounding anal opening and bearing numerous pores and fewer setae.

Dorsum. Multilocular pores (Fig. 22D) circular, each $8-9 \mu \mathrm{m}$ in diameter with a single wide central loculus and apparently 8-12 (mainly 10) outer loculi; scattered on head and thorax but in 5 longitudinal lines on each side of abdomen, mostly each pore accompanied by 2 short flagellate setae. Sclerotised anal plate with raised multilocular pores (Fig. 22H), each about $10 \mu \mathrm{m}$ wide, located at centre of a raised, circular sclerotised derm, each raised area 25-35 $\mu \mathrm{m}$ wide; also with 12-14 setae, each 20-30 $\mu \mathrm{m}$ long, and medially with 2 longer pairs of setae, each about $45 \mu \mathrm{m}$ long. Stout, short marginal setae, each about $10 \mu \mathrm{m}$ long with a wide base (Fig. 22B), and short slender flagellate setae (Fig. 22C), each 10-18 $\mu \mathrm{m}$ long, scattered throughout.

Venter. Multilocular oval pores (Fig. 22M; blackened on main drawing), each $10 \mu \mathrm{m}$ wide with a bilocular centre and 10 outer loculi, located near each peritreme of thoracic spiracles and very sparse elsewhere on thorax. Multilocular circular pores (Fig. 22D) similar to those on dorsum, each 8-9 $\mu \mathrm{m}$ wide with a wide circular centre and 8-12 (mainly 10) outer loculi, distributed in longitudinal segmental lines on thorax and abdomen. Short, slender flagellate setae (Fig. 22C), similar to those on dorsum, each 10-18 $\mu \mathrm{m}$ long, scattered on head and thorax, and in a single row across each abdominal segment. Hairs (Fig. 22I) with swollen base very sparse on posterior segments. Head with 2 long submedial setae (Fig. 22N), each 90-100 $\mu \mathrm{m}$ long; abdomen with setae, each 30-70 $\mu \mathrm{m}$ long, in 4 longitudinal lines, one pair of lines medial and other submedial. Posterior end of abdomen with 2 pairs of long caudal setae (Fig. 22J), each 300-420 $\mu \mathrm{m}$ long, setae of thinner pair often broken or displaced due to distortion of body and thus many specimens with apparently only one pair of caudal setae (as shown in Morrison, 1928, figure 42). Cicatrices (Fig. 22K) present submedially in a single longitudinal line of 6 on each side of body, becoming smaller posteriorly, from 30 to $20 \mu \mathrm{m}$ in diameter. 


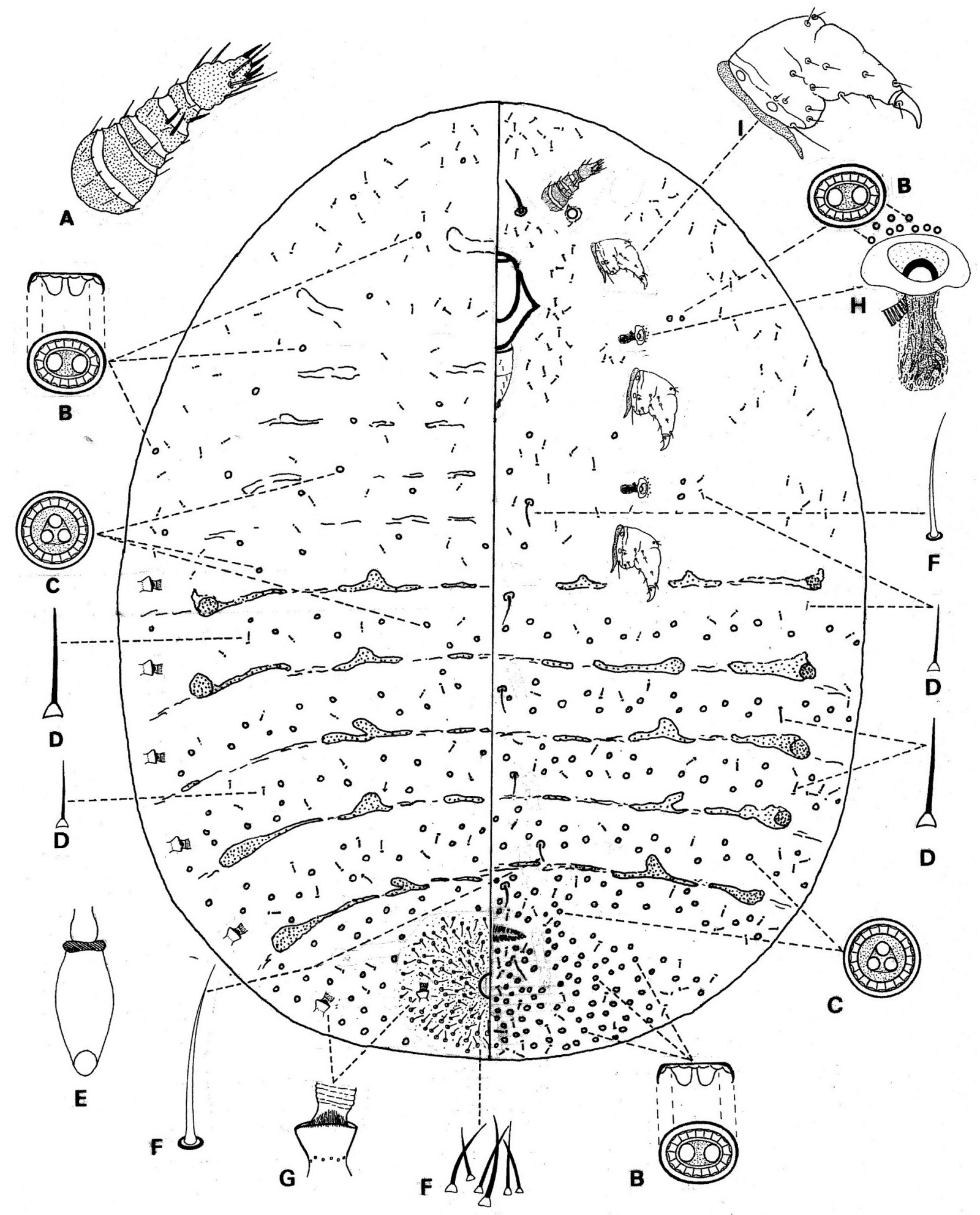

FIGURE 20. Paracoelostoma peruvianum Morrison. Adult female. A. antenna; B. multilocular pore with bilocular centre; C. multilocular pore with triangular centre; D. slender flagellate setae; E. anal tube; F. dense group of flagellate setae around anal opening; G. abdominal spiracle; H. thoracic spiracle with perispiracular multilocular pores; I. prothoracic leg. 


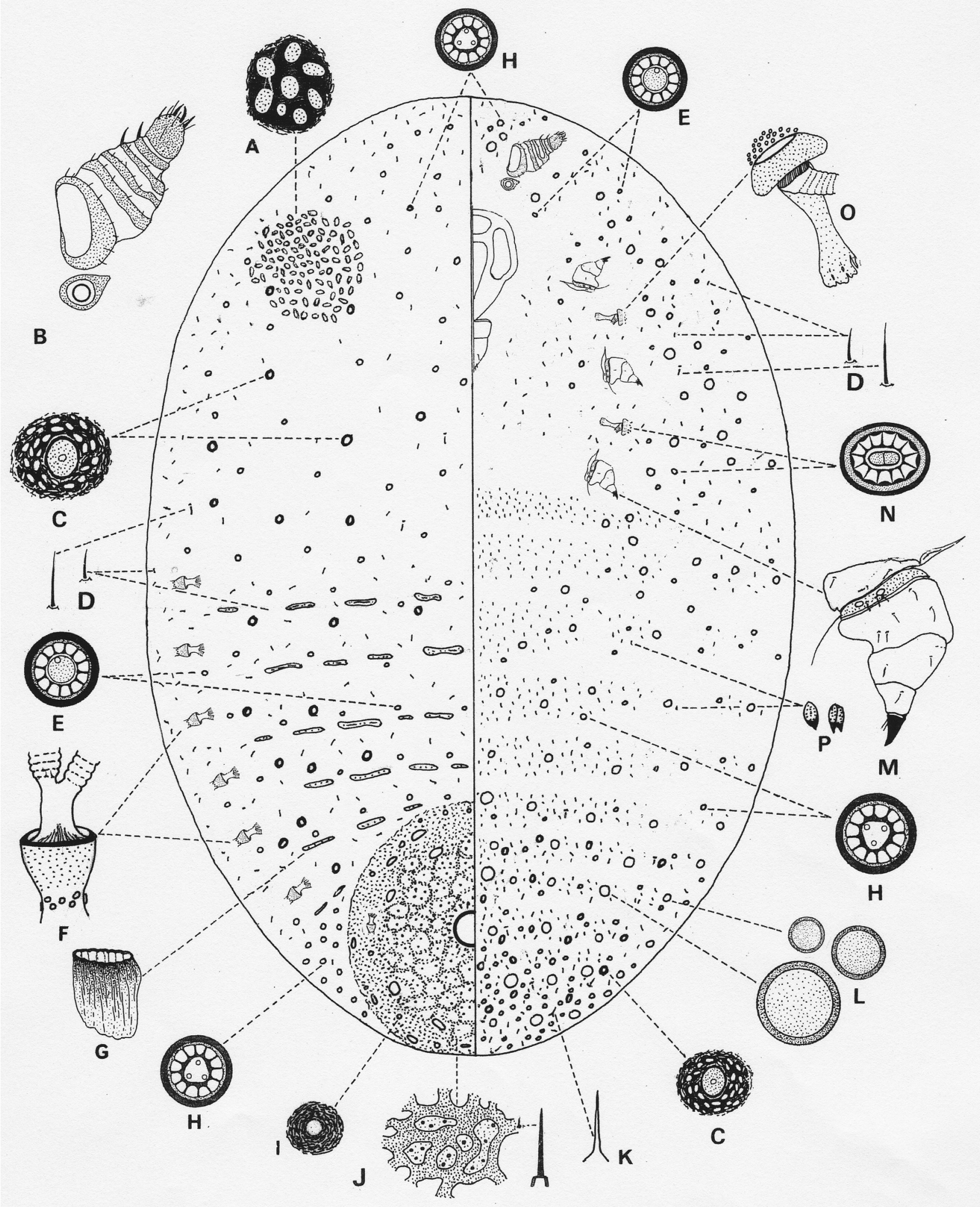

FIGURE 21. Paracoelostoma peruvianum Morrison. Third-instar female (preadult). A. areolated derm of whole dorsal surface; B. antenna; C. circular-oval cicatrix-like membranous structure; D. short flagellate setae; E. multilocular pore with a wide circular centre; F. abdominal spiracle; G. apodeme of intersegmental line; H. multilocular pore with triangular centre; I. raised simple pore; J. detail of sclerotised plate showing isolated membranous derm with pores and enlargement of one seta; $\mathrm{K}$. short hair; L. cicatrices; M. metathoracic leg; N. multilocular oval pore with wide bilocular centre; O. thoracic spiracle with numerous perispiracular multilocular pores; P. spinules. 


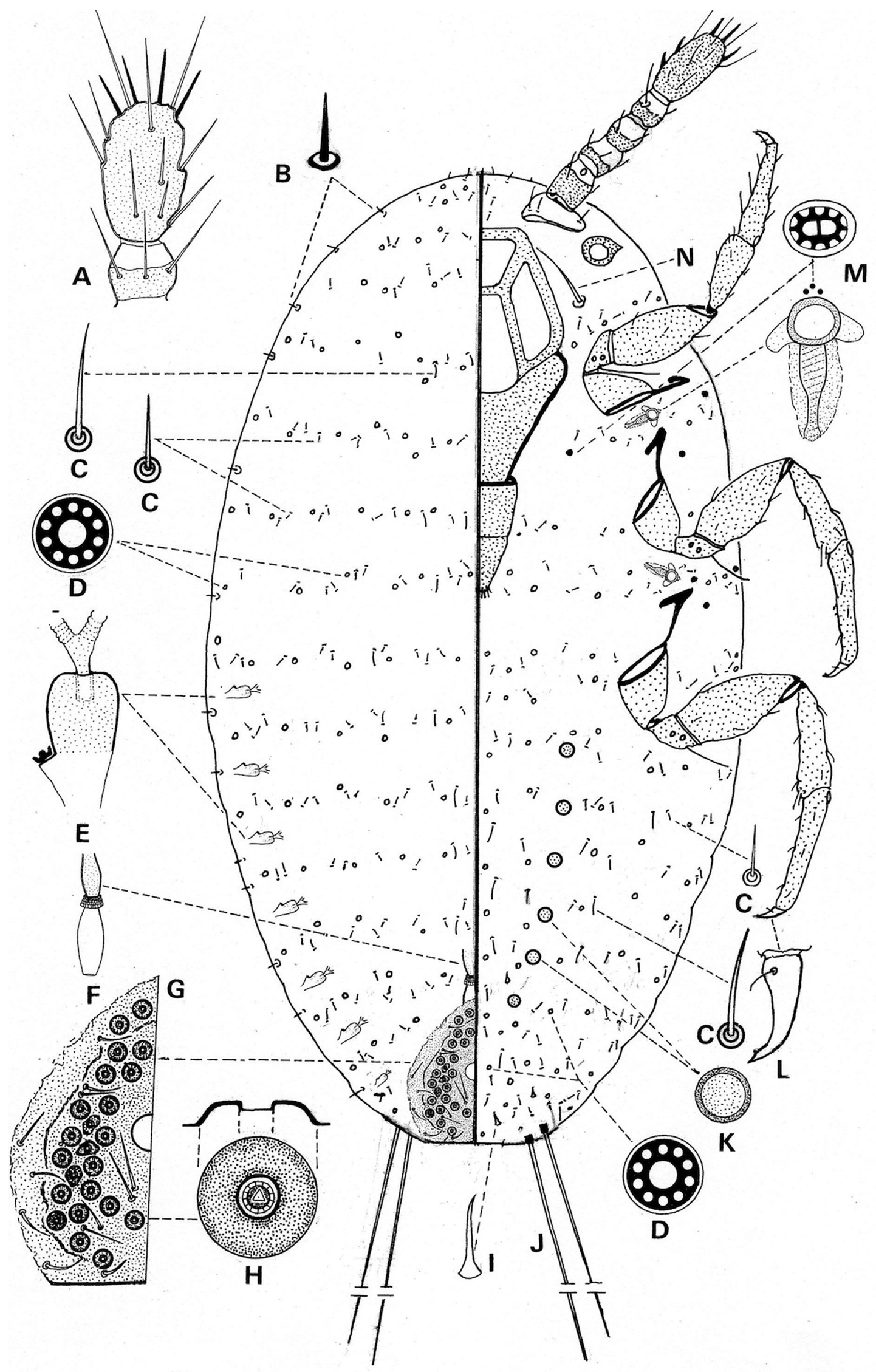

FIGURE 22. Paracoelostoma peruvianum Morrison. First-instar nymph. A. apical segments of antenna; B. marginal seta; C. short flagellate setae on dorsum and venter; D. multilocular pore; E. abdominal spiracle; F. anal tube; G. detail of sclerotised plate; H. multilocular raised pore on sclerotised plate; I. ventral hair with swollen base; J. long caudal setae; K. cicatrix; L. metathoracic claw with denticle; M. thoracic spiracle with perispiracular multilocular pores; N. long seta of submedial head. 


\section{Acknowledgements}

We are grateful to Dr Dug R. Miller and Debra Creel for loan of the USNM scale insects and for providing information on specimens housed there. We thank to Dr Ana Peronti for examining and photographing slidemounted type specimens of $N$. xerophila Hempel housed in IBSP, São Paulo, Brazil. We thank Dr Chris Hodgson for generously preparing the illustration and draft description of the adult male of $M$. schraderae and the draft description of $N$. xerophila, as well as carefully editing earlier versions of the manuscript. We also thank Dr Takumasa Kondo for the translation of Hempel's original Portuguese description of N. xerophila and Professor San-an Wu for translation of a section of Tang \& Hao (1995). Dr Kondo and Dr Gillian W. Watson kindly reviewed a draft of the manuscript and made many useful comments and corrections.

\section{References}

Ben-Dov, Y. (2005) A Systematic Catalogue of the Scale Insect Family Margarodidae (Hemiptera: Coccoidea) of the World. Intercept Ltd., Wimborne, 400 pp. [U.K.]

Ben-Dov, Y. (2011) An updated checklist of the scale insects (Hemiptera: Coccoidea) of the Margarodidae sensu lato group. Zootaxa, 2859, 1-62.

Ben-Dov, Y. (2014) ScaleNet, Nautococcus. Available from: http://www.sel.barc.usda.gov/catalogs/monophle/NautococcusAll.htm (accessed 23 March 2014)

Ben-Dov, Y. Miller, D.R. \& Gibson, G.A.P. (2014) ScaleNet: A Database of Scale Insects of the World. Available from: http:// www.sel.barc.usda.gov/scalenet/scalenet.htm (accessed 23 March 2014)

Cockerell, T.D.A. (1899) Three new Coccidae from Brazil. The Canadian Entomologist, 31, 43-45. http://dx.doi.org/10.4039/ent3143-2

Cockerell, T.D.A. (1902a) A contribution to the classification of the Coccidae. The Entomologist, 35, 232-233, 257-260.

Cockerell, T.D.A. (1902b) Some Coccidae from Mexico. Annals and Magazine of Natural History, Series 7, 10, 465-472.

Cook L.G., Gullan, P.J. \& Trueman, H.E. (2002) A preliminary phylogeny of the scale insects (Hemiptera: Sternorrhyncha: Coccoidea) based on nuclear small-subunit ribosomal DNA. Molecular Phylogenetics and Evolution, 25, 43-52. http://dx.doi.org/10.1016/s1055-7903(02)00248-8

Ferris, G.F. (1918) Notes on Coccidae (Hemiptera). The Canadian Entomologist, 50, 221-225.

Foldi, I. (1995) Les Cochenilles du Mexique. Annales de la Société entomologique de France, New Series, 31, 165-178.

Foldi, I. (1997) Defense strategies in scale insects: phylogenetic inference and evolutionary scenarios (Hemiptera, Coccoidea). In: Grandcolas, P. (Ed.), The Origin of Biodiversity in Insects: Phylogenetic Tests of Evolutionary Scenarios. Mémoires du Muséum national d'Histoire naturelle, 173, pp. 203-230.

Foldi, I. (2001) A world list of extant and fossil species of Margarodidae sensu lato (Hemiptera, Coccoidea). Nouvelle Revue Entomologie, New Series, 18, 195-231.

Foldi, I. (2005) Ground pearls: a generic revision of the Margarodidae sensu stricto. Annales de la Société entomologique de France, New Series, 41, 81-125. http://dx.doi.org/10.1080/00379271.2005.10697442

Foldi, I. (2006) Deux nouvelles Cochenilles du Brésil et de l'Équateur (Hemiptera, Sternorhyncha, Coccoidea). Bulletin de la Société entomologique de France, 111, 101-113.

Foldi, I. (2009) Archaeococcoid scale insects (Hemiptera: Coccoidea) from the tropical high mountains of the Andean Cordillera. Zootaxa, 2300, 1-38.

Foldi, I. (2011) Archaeococcoides du Mexique: une espèce nouvelle de Cryptokermes Hempel, 1900, et description des stades de développement de C. mimosae Foldi, 1995 (Hemiptera, Coccoidea, Coelostomidiidae). Bulletin de la Société entomologique de France, 116, 483-493.

Foldi, I. \& Williams, D.J. (2013) A new species of the Neotropical scale insect genus Laurencella Foldi, 1995, from Guyana (Hemiptera, Coccoidea, Monophlebidae, Llaveiini). Bulletin de la Société entomologique de France, 118, 87-94.

Gullan, P.J. \& Sjaarda, A.W. (2001) Trans-Tasman Platycoelostoma Morrison (Hemiptera: Coccoidea: Margarodidae) on endemic Cupressaceae, and the phylogenetic history of margarodids. Systematic Entomology, 26, 257-278. http://dx.doi.org/10.1046/j.1365-3113.2001.00145.x

Gullan, P.J. \& Cook, L.G. (2007) Phylogeny and higher classification of the scale insects (Hemiptera: Sternorrhyncha: Coccoidea). In: Zhang, Z.-Q. \& Shear, W.A. (Eds) Linnaeus Tercentenary: Progress in Invertebrate Taxonomy. Zootaxa, $1668,413-425$.

Hempel, A. (1900) As Coccidas Brazileiras. Revista do Museu Paulista, São Paulo 4, 365-537, plates V-XII.

Hempel, A. (1932) Descripção de vinte a duas espècies novas de coccideos (Hemiptera - Homoptera). Revista de Entomologia, 2,310-339.

Hodgson, C. \& Foldi, I. (2005) Preliminary phylogenetic analysis of the Margarodidae sensu Morrison and related taxa (Hemiptera: Coccoidea) based on adult male morphology. In: Erkiliç, L. \& Kaydan, M.B. (Eds.), Proceedings of the Xth International Symposium on Scale Insect Studies, 19-23 April 2004. Adana Zirai Muscadele Arastirma Enstitusu, Adana, pp. 35-48. [Turkey]

Hodgson, C. \& Foldi, I. (2006) A review of the Margarodidae sensu Morrison (Hemiptera: Coccoidea) and some related taxa based on the morphology of adult males. Zootaxa, 1263, 1-250. 
Hodgson, C.J., Gamper, H., Bogo, A. \& Watson, G. (2007) A taxonomic review of the margarodid genus Stigmacoccus Hempel (Hemiptera: Sternorrhyncha: Coccoidea: Stigmacoccidae), with some details on their biology. Zootaxa, 1507, 1-55.

Hodgson, C.J. \& Hardy, N.B. (2013) The phylogeny of the superfamily Coccoidea (Hemiptera: Sternorrhyncha) based on the morphology of extant and fossil macropterous males. Systematic Entomology, 38, 794-804.

http://dx.doi.org/10.1111/syen.12030

International Commission on Zoological Nomenclature (1999) International Code of Zoological Nomenclature. $4^{\text {th }}$ Edition. The Natural History Museum, London, 306 pp. Avaiable from: http://www.iczn.org/code (accessed 23 March 2014)

Koteja, J. (1974) On the phylogeny and classification of the scale insects (Homoptera, Coccinea) (discussion based on the morphology of the mouthparts). Acta Zoologica Cracoviensia, 19, 267-325.

Koteja, J. (1996) Scale insects (Homoptera: Coccinea) a day after. In: Schaefer, C.W. (Ed.), Studies on Hemipteran Phylogeny. Proceedings of Thomas Say Publications in Entomology, Entomological Society of America, Lanham, Maryland, pp. 65-88.

Kozár, F. (2004) Ortheziidae of the World. Plant Protection Institute, Hungarian Academy of Sciences, Budapest, 525 pp. [Hungary]

Kozár, F. \& Foldi, I. (2002) The water scale insects of the mysterious family Carayonemidae (Hemiptera: Coccoidea). Bollettino di Zoologia Agraria e di Bachicoltura (Milano), 33 (3), 197-201.

Kozár, F. \& Konczné Benedicty, Z. (2000) Carayonemidae of the Neotropical Region with the descriptions of new genera and species (Homoptera: Coccoidea). Folia Entomologica Hungarica, 61, 71-82.

Lizer y Trelles, C.A. (1936) Algunas cochinillas nuevas para la fauna de la República Argentina. Physis (Buenos Aires), 12 , $113-116$.

Lizer y Trelles, C.A. (1939) Catálogo sistemático razonado de los cóccidos (Hom. Sternor) vernáculos de la Argentina. Physis, 17, 157-210. [Buenos Aires]

Morales, C.F. (1991) Margarodidae (Insecta: Hemiptera). In: Duval, C.T. (Series Ed.), Fauna of New Zealand, Ko te Aitanga Pepeke o Aotearoa. No. 21. DSIR Plant Protection, Auckland, 123 pp.

Morrison, H. (1927) Descriptions of new genera and species belonging to the coccid family Margarodidae. Proceedings of the Biological Society of Washington, 40, 99-110.

Morrison, H. (1928) A classification of the higher groups and genera of the coccid family Margarodidae. United States Department of Agriculture, Washington D.C. Technical Bulletin, 52, 1-239.

Newstead, R. (1920) Observations on scale insects (Coccidae) - VI. Bulletin of Entomological Research, 10, $175-207$. http://dx.doi.org/10.1017/s0007485300043984

Normark, B.B. (2003) The evolution of alternative genetic systems in insects. Annual Review of Entomology, 48, $397-423$.

Noyes, J.S. (2012) Universal Chalcidoidea Database. World Wide Web electronic publication. Available from: http:// www.nhm.ac.uk/chalcidoids (accessed 6 March 2013)

Pellizzari, G. \& Williams, D. (2013) Simple rules on adjectival endings in zoological nomenclature and their use in scale insect names (Hemiptera: Sternorrhyncha: Coccoidea), with some corrections to combinations in common use. Zootaxa, 3710 (5), 401-414. http://dx.doi.org/10.11646/zootaxa.3710.5.1

Ross, L., Pen, I. \& Shuker, D.M. (2010) Genomic conflict in scale insects: the causes and consequences of bizarre genetic systems. Biological Reviews, 85, 807-828. http://dx.doi.org/10.1111/j.1469-185x.2010.00127.x

Tang, F.T. \& Hao, J. (1995) The Margarodidae and Others of China. Chinese Agricultural Science Technology Presse, Beijing, $738 \mathrm{pp}$.

The Plant List (2010) Manilkara zapota (L.) P. Royen. Available from: http://www.theplantlist.org/tpl/record/kew-120271 (accessed 15 October 2013)

Unruh, C.M. \& Gullan, P.J. (2008) Identification guide to species in the scale insect tribe Iceryini (Coccoidea: Monophlebidae). Zootaxa, 1803, 1-106.

Vayssière, P. (1939) Un nouveau genre de cochenille à Panama. Bulletin de la Société entomologique de France, 44, $124-127$.

Vayssière, P. \& Hughes-Schrader, S. (1948) Étude morphologique et biologique Nautococcus schraderae Vayss. (CoccoideaMargarodidae). Mémoires du Museum National d'Histoire Naturelle, New Series, Série A (Zoologie), 26, 57-74.

Williams, D.J. (1985) T.D.A. Cockerell's scale insects (Homoptera: Coccoidea) in the British Museum (Natural History). Folia Entomologica Hungarica, 46, 215-240.

Williams, D.J. (2011) Some words used in scale insect names (Hemiptera: Sternorrhyncha: Coccoidea). Zootaxa, 3087, 66-68.

Williams, D.J. (2013) Family-group names in the scale insects (Hemiptera: Sternorrhyncha: Coccoidea) - a supplement. Zootaxa, 3616 (4), 325-344. http://dx.doi.org/10.11646/zootaxa.3616.4.2

Williams, D.J. \& Granara de Willink, M.C. (1992) Mealybugs of Central and South America. CAB International, London, England, $635 \mathrm{pp}$.

Williams, D.J. \& Gullan, P.J. (2008) A revision of the Neotropical scale insect genus Protortonia Townsend (Hemiptera: Coccoidea: Monophlebidae: Llaveiini). Journal of Natural History, 42, 77-128. http://dx.doi.org/10.1080/00222930701838054

Yokogawa, T. \& Yahara, T. (2009) Mitochondrial phylogeny certified PGL (paternal genome loss) is of single origin and haplodiploidy sensu stricto (arrhenotoky) did not evolve from PGL in the scale insects (Hemiptera: Coccoidea). Genes and Genetic Systems, 84, 57-66. http://dx.doi.org/10.1266/ggs.84.57 